\title{
Data report: diatom biostratigraphy of IODP Site U1371 in the South Pacific Ocean'
}

\author{
Itsuki Suto ${ }^{2}$ and Go-Ichiro Uramoto ${ }^{3}$
}

\begin{abstract}
Chapter contents

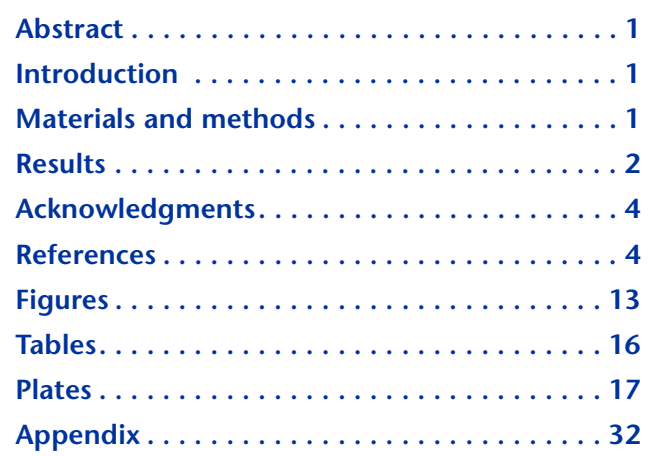

'Suto, I., and Uramoto, G.-I., 2015. Data report: diatom biostratigraphy of IODP Site U1371 in the South Pacific Ocean. In D'Hondt, S., Inagaki, F., Alvarez Zarikian, C.A., and the Expedition 329 Scientists, Proceedings of the Integrated Ocean Drilling Program, 329: Tokyo (Integrated Ocean Drilling Program Management International, Inc.). doi:10.2204/iodp.proc.329.203.2015

${ }^{2}$ Department of Earth and Planetary Sciences, Graduate School of Environmental Studies, Nagoya University, Furo, Chikusa, Nagoya, Aichi 464-8601, Japan.

suto.itsuki@a.mbox.nagoya-u.ac.jp

${ }^{3}$ Kochi Institute for Core Sample Research, Japan Agency for Marine-Earth Science and Technology (JAMSTEC), Monobe B200, Nankoku, Kochi 7838502, Japan.

\begin{abstract}
Diatom biostratigraphic analyses of late Miocene to Pleistocene sediments in Hole U1371D of Integrated Ocean Drilling Program Expedition 329 in the South Pacific Gyre are invoked although several reworked diatoms are included. The nine diatom biozones recognized indicate an estimated age of $8.67 \mathrm{Ma}$ at $\sim 100$ meters below seafloor. Moreover, abundant occurrences of diatom resting spores at $\sim 2.5 \mathrm{Ma}$ indicate a eutrophication increase.
\end{abstract}

\section{Introduction}

During Integrated Ocean Drilling Program (IODP) Expedition 329 , pelagic sediments were drilled in the abyssal environments of the South Pacific Gyre (SPG) (Fig. F1). The SPG is the largest of the ocean gyres and its center is farther from continents than the center of any other gyre. The SPG contains the largest portion of seafloor that has never been explored with scientific ocean drilling, and paleoceanographic transition of this region is not clearly understood.

At IODP Site U1371, located just south of the southern gyre edge, shipboard study revealed abundant and continuous occurrences of fossil diatoms in cored sediments (Expedition 329 Scientists, 2011). Diatom assemblages provide an essential age-control reference for the detailed examination of paleoceanographic evolution. This report presents diatom occurrences and abundances for the age-diagnostic taxa recovered in cores from Hole U1371D.

\section{Materials and methods}

The sediment at Site U1371 consists of $\sim 104 \mathrm{~m}$ of diatom ooze and $\sim 20 \mathrm{~m}$ of pelagic clay (Fig. F2). The strata of this site are divided into two lithologic units based on their markedly different modal composition. Unit I is ooze with average diatom and clay content of $56 \%$ and $17 \%$, respectively. Unit II is a mixture of clay, zeolite, and red-brown to yellow-brown semiopaque iron manganese oxides. Unit II contains an average modal abundance of up to $26 \%$ diatoms but only in the upper $5 \mathrm{~m}$ of the unit where the lithology transitions from ooze to clay. Other minor constituents of the sediment include quartz, pyrite, manganese oxide/hydroxide, and biogenic particles including radiolarians, spicules, and silicoflagellates. 
Eighty-two microslides prepared for diatom analyses contained abundant and well-preserved fossil diatom, resting spore, radiolarian, and silicoflagellate assemblages. To prepare the microslides, silty to clayey sediments containing diatoms were selected between Samples 329-U1371D-1H-1W, 66-67 cm (top depth $=0.66 \mathrm{~m}$ uncompressed core depth below seafloor [CSF-A]), and 14H-4W, 35-36 cm (126.25 m CSF-A).

For standard diatom analysis, $\sim 0.5 \mathrm{~g}$ of each wet sample was processed; the methods of sample preparation, counting, and other procedures that we followed were basically the same as those of Koizumi (1968) and Akiba (1982b, 1986) with a minor modification. Counting methods for vegetative cell valves of "normal" diatoms and Chaetoceros resting spores were followed after Akiba (1986) and Suto (2006b), respectively (Table T1). A single vegetative cell valve of Centrales species was counted as one when more than a half of a valve was observed. Broken specimens of Pennales species were counted as one valve when two apices were observed. Other criteria for identification of specific genera were used following after several papers (see the floral reference list for diatom taxonomy in the "Appendix").

Diatom abundance is expressed as an approximate number of diatom valves per slide calculated using the length of scanning lines. To determine the fluctuation of diatom assemblages, 100 vegetative valves of normal diatoms were counted at species level for each sample. After counting, the slides were scanned to record the presence of species missed in the original tally as indicated by a "+" in Table T1. The resting spore abundance is defined here as the number of spore valves encountered during a count of 100 vegetative cell valves of other diatom species.

In diatom biostratigraphic assignments, we applied the diatom zonal scheme of Harwood and Maruyama (1992) for examined samples. Diatom event (first appearance datum [FAD] and last appearance datum [LAD]) ages used in this study were after the midpoint of average range model (ARM) of Cody et al. (2008), which recalibrated the ages to the Cande and Kent (1995) timescale (Figs. F2, F3), although the usefulness of their ages of bioevents has been up for discussion. Magnetostratigraphic ages are presumed with the diatom biostratigraphic results according to the shipboard results in Expedition 329 Scientists (2011), although the polarity chrons were not described in this study. All subchron boundaries and diatom bioevent ages were converted to the Gradstein et al. (2004) timescale.

\section{Results}

All samples from Hole U1371D contained sufficient diatoms per slide ( $>400$, usually nearly 1000 valves) and Chaetoceros resting spores ( $>100$, usually nearly 400 valves), except for Sample 329-U1371D-12H-2W, $45-46 \mathrm{~cm}$ (104.35 m CSF-A), with very rare diatoms, and barren samples between Samples 12H-3W, 45-46 $\mathrm{cm}$ (105.85 m CSF-A), and 14H-4W, 35-36 cm (126.25 m CSF-A). The preservation and abundance of fossil diatoms and resting spores are good and common to abundant throughout all microslides except for some rare and barren samples mentioned above (Table T1). Diatom assemblages are mostly composed of useful biostratigraphic markers with continuous and abundant occurrences (Fig. F2; Tables T1, T2).

Core materials from Expedition 329 Hole U1371D investigated in this study correspond to several diatom bioevents (i.e., FAD and LAD) defining the diatom zones of Harwood and Maruyama (1992) (Fig. F3):

- Thalassiosira lentiginosa Zone (0.0-0.54 Ma, recalculated ages in midpoint of ARM by Cody et al. [2008]),

- Actinocyclus ingens Zone (0.54-1.24 Ma),

- Fragilariopsis kerguelensis/Thalassiosira kolbei/Thalassiosira vulnifica Zone (1.24-2.48 Ma),

- Thalassiosira insigna-T. vulnifica/Fragilariopsis interfrigidaria Zone (2.48-4.11 Ma),

- Fragilariopsis barronii Zone (4.11-4.40 Ma),

- Thalassiosira inura Zone (4.40-4.74 Ma),

- Shionodiscus oestrupii/Fragilariopsis reinholdii b Subzone (4.74-6.00 Ma),

- F. reinholdii a/A. ingens var. ovalis Zone (6.00-8.67 $\mathrm{Ma})$, and

- Thalassiosira torokina Zone (8.67-? Ma).

However, the bioevents that define the bottoms of the F. kerguelensis Zone, the T. kolbei Zone, the T. insigna-T. vulnifica Zone, the S. oestrupii Zone, and Subzone a of the $F$. reinholdii Zone were not clarified because of the absence of index species (Fig. F2). Here, the magnetostratigraphic chron and subchron datums are presumed according to shipboard research results (Expedition 329 Scientists, 2011). We selected biostratigraphic diatom markers that did not contradict the magnetostratigraphic datums (Fig. F3). Several datums of other age indicators conflicted with chron and subchron datums, and these indicators were not used in this study because they might 
include reworked and/or contaminated diatoms. Moreover, some diatom species also were not used because of their sporadic and rare occurrences (Fig. F2).

The LAD of $A$. ingens Rattray $(0.5-0.57 \mathrm{Ma})$ is recognized between Samples 329-U1371D-1H-3W, 66-67 $\mathrm{cm}$, and $1 \mathrm{H}-4 \mathrm{~W}, 112-113 \mathrm{~cm}(4.64 \pm 0.98 \mathrm{~m}$ CSF-A). The interval between the top of Hole U1371D and the LAD of $A$. ingens is assigned to the T. lentiginosa Zone of Harwood and Maruyama (1992).

The LAD of $F$. barronii (Gersonde) Gersonde et Bárcena (1.19-1.29 Ma) is recognized between Samples $3 \mathrm{H}-3 \mathrm{~W}, 112-113 \mathrm{~cm}$, and $3 \mathrm{H}-4 \mathrm{~W}, 112-113 \mathrm{~cm}$ (21.77 $\pm 0.75 \mathrm{~m}$ CSF-A). The interval between the LAD of $F$. barronii and the LAD of $A$. ingens is assigned to the $A$. ingens Zone of Harwood and Maruyama (1992).

In the interval between the LAD of $F$. barronii and the LAD of T. insigna (Jousé) Harwood et Maruyama, the F. kerguelensis Zone and the T. kolbei Zone are defined by Harwood and Maruyama (1992), but the boundaries of these zones, which are defined by the LAD of T. kolbei (Jousé) Gersonde (1.98 Ma) and the LAD of T. vulnifica (Gombos) Fenner (2.17 Ma), are not recognized because of the absence and sporadic occurrences of T. kolbei and T. vulnifica.

The LAD of $T$. insigna (2.45-2.5 Ma) is recognized between Samples 5H-2W, 112-113 cm, and 5H-3W, $112-113 \mathrm{~cm}(38.87 \pm 0.75 \mathrm{~m}$ CSF-A), and assigned to the bottom of the T. vulnifica Zone of Harwood and Maruyama (1992). The LAD of Shionodiscus tetraoestrupii var. reimeri (Mahood et Barron) Alverson et al. (1.31-1.34 Ma), the LAD of Proboscia barboi (Brun) Jordan et Priddle (1.6-1.73 Ma), the FAD of Fragilariopsis obliquecostata (Van Heurck) Heiden et Kolbe (1.66-1.73 Ma), the FAD of Shionodiscus gracilis (Karsten) Alverson et al. (1.87 Ma), and the FAD of $F$. kerguelensis (2.18-2.21 Ma) are also recognized in the intervals consisting of the F. kerguelensis Zone, the $T$. kolbei Zone, and the T. vulnifica Zone (Fig. F2; Table T2).

The FAD of T. vulnifica (3.12-3.18 Ma), which is assigned to the bottom of the T. insigna-T. vulnifica Zone, is not defined in this study because of sporadic occurrences.

The FAD of $F$. interfrigidaria (McCollum) Gersonde et Bárcena (3.93-4.19 Ma), which defines the bottom of the F. interfrigidaria Zone of Harwood and Maruyama (1992), is recognized between Samples 7H-4W, 15-16 $\mathrm{cm}$, and 7H-5W, 15-16 cm (60.30 $\pm 0.75 \mathrm{~m} \mathrm{CSF-A})$. The LAD of T. inura Gersonde (2.53-2.55 Ma), the FAD of Actinocyclus actinochilus (Ehrenberg) Simonsen (2.72-2.81 Ma), and the LAD of Fragilariopsis praeinterfrigidaria (3.45-3.49 Ma) are also recognized in the interval consisting of the T. insigna-T. vulnifica Zone and the $F$. interfrigidaria Zone (Fig. F2; Table T2).

The FAD of $F$. barronii (4.28-4.52 Ma), which defines the bottom of the $F$. barronii Zone of Harwood and Maruyama (1992), is recognized between Samples $7 \mathrm{H}-6 \mathrm{~W}, 30-31 \mathrm{~cm}$, and $8 \mathrm{H}-1 \mathrm{~W}, 82-83 \mathrm{~cm}(63.96 \pm$ 1.26 m CSF-A).

The FAD of $T$. inura (4.71-4.77 Ma), which defines the bottom of the T. inura Zone of Harwood and Maruyama (1992), is recognized between Samples $8 \mathrm{H}-4 \mathrm{~W}, 82-83 \mathrm{~cm}$, and $8 \mathrm{H}-5 \mathrm{~W}, 82-83 \mathrm{~cm}(70.47 \pm$ $0.75 \mathrm{~m}$ CSF-A). The FAD of Rouxia diploneides Schrader (4.61-4.7 Ma) is also recognized between Samples $8 \mathrm{H}-1 \mathrm{~W}, 82-83 \mathrm{~cm}$, and $8 \mathrm{H}-2 \mathrm{~W}, 82-83 \mathrm{~cm}$ (65.97 $\pm 0.75 \mathrm{~m} \mathrm{CSF-A}$ ).

The bottom of the $S$. oestrupii Zone of Harwood and Maruyama (1992), defined by the FAD of $S$. oestrupii (4.8-4.95 Ma), was not determined.

The LAD of Hemidiscus triangularus (Jousé) Harwood et Maruyama (5.14-6.86 Ma), which defines the bottom of Subzone b of the F. reinholdii Zone, is observed between Samples 9H-4W, 92-93 cm, and 9H$5 \mathrm{~W}, 58-59 \mathrm{~cm}(79.90 \pm 0.58 \mathrm{~m}$ CSF-A $)$.

The FAD of Thalassiosira miocenica Schrader (6.25$8.33 \mathrm{Ma}$ ), which defines the bottom of Subzone a of the $F$. reinholdii Zone, is not recognized in this study.

The FAD of $A$. ingens var. ovalis (8.6-8.74 Ma) defines the boundary between the $A$. ingens var. ovalis Zone and the T. torokina Zone; however, the FAD of $A$. ingens var. ovalis and the FAD of Hemidiscus karstenii Jousé in Jousé et al. (9.68-10.24 Ma) may be uncertain because lower samples lack continuous occurrences of those diatoms (Fig. F2; Table T2).

These biostratigraphic results match well with those of Cortese and Alvarez Zarikian (2015) based on radiolarian biostratigraphy from 30 meters below seafloor (mbsf) to the top of core and at $\sim 100 \mathrm{mbsf}$, although the radiolarian and diatom biostratigraphic ages from 70 to $60 \mathrm{mbsf}$ have more differences. The reason for these differences might be that reworked siliceous fossils are included in these cores.

Moreover, the abundant occurrence of Chaetoceros resting spores, which are a major contributor to primary production in nearshore upwelling regions and coastal areas (Rines and Hargraves, 1988) and are usually taken as a measure of diatom productivity and an indicator of nutrient-rich conditions (Sancetta, 1982), may indicate that eutrophication increased in the coastal regions after upwelling strengthened (Suto, 2006b). Also, the peak at 2.5 Ma might coincide with the Pacific Chaetoceros Explosion Event-2 (Suto et al., 2012), which is charac- 
terized by relatively higher occurrences at $\sim 2.5 \mathrm{Ma}$ in the North Pacific region.

\section{Acknowledgments}

We express many thanks to all Expedition 329 scientists, especially Co-Chief Scientists Steven L. $\mathrm{D}^{\prime}$ Hondt and Fumio Inagaki and the crew of the R/V JOIDES Resolution for their participation. We wish to thank Professor Toshitsugu Yamazaki (University of Tokyo) for invaluable discussions on geomagnetic polarity. Our thanks are also extended to our colleagues at the Laboratory of Geobiology, Nagoya University and JAMSTEC. This research used samples and data provided by the Integrated Ocean Drilling Program (IODP).

\section{References}

Abbott, W.H., and Andrews, G.W., 1979. Middle Miocene marine diatoms from the Hawthorne formation within the Ridgeland Trough, South Carolina and Georgia. Micropaleontology, 25(3):225-271. http://dx.doi.org/10.2307/1485301

Abbott, W.H., and Ernissee, J.J., 1983. Biostratigraphy and paleoecology of a diatomaceous clay unit in the Miocene Pungo River Formation of Beaufort County, North Carolina. Smithsonian Contributions to Paleobiology, 53:287-353.

Akiba, F., 1982a. Late Quaternary diatom biostratigraphy of the Bellingshausen Sea, Antarctic Ocean. Report of the Technology Research Center, Japan National Oil Corporation, 16:31-74.

Akiba, F., 1982b. Taxonomy and biostratigraphic significance of a new diatom, Thalassionema schraderi. Bacillaria, 5:43-61.

Akiba, F., 1986. Middle Miocene to Quaternary diatom biostratigraphy in the Nankai Trough and Japan Trench, and modified lower Miocene through Quaternary diatom zones for middle-to-high latitudes of the north Pacific. In Kagami, H., Karig, D.E., Coulbourn, W.T., et al., Initial Reports of the Deep Sea Drilling Project, 87: Washington, DC (U.S. Govt. Printing Office), 393-481. http://dx.doi.org/10.2973/dsdp.proc.87.106.1986

Akiba, F., Hiramatsu, C., and Yanagisawa, Y., 1993. A Cenozoic diatom genus Cavitatus Williams; an emended description and two new biostratigraphically useful species, C. lanceolatus and C. rectus from Japan. Bulletin of the National Science Museum, Series C: Geology \& Paleontology (Tokyo), 19(1):11-39.

Akiba, F., and Yanagisawa, Y., 1986. Taxonomy, morphology and phylogeny of the Neogene diatom zonal marker species in the middle-to-high latitudes of the North Pacific. In Kagami, H., Karig, D.E., Coulbourn, W.T., et al., Initial Reports of the Deep Sea Drilling Project, 87: Washington, DC (U.S. Govt. Printing Office), 483554.

http://dx.doi.org/10.2973/dsdp.proc.87.107.1986
Alverson, A.J., Kang, S.-H., and Theriot, E.C., 2006. Cell wall morphology and systematic importance of Thalassiosira ritscheri (Hustedt) Hasle, with a description of Shionodiscus gen. nov. Diatom Research, 21(2):251-262. http://dx.doi.org/10.1080/0269249X.2006.9705667

Andrews, G.W., 1976. Miocene marine diatoms from the Choptank Formation, Calvert County, Maryland. U.S. Geological Survey Professional Paper, 910. http://pubs.usgs.gov/pp/0910/report.pdf

Andrews, G.W., 1980. Neogene diatoms from Petersburg, Virginia. Micropaleontology, 26(1):17-48.

http://dx.doi.org/10.2307/1485272

Armand, L.K., and Zielinski, U., 2001. Diatom species of the genus Rhizosolenia from Southern Ocean sediments: distribution and taxonomic notes. Diatom Research, 16(2):259-294. http://dx.doi.org/10.1080/0269249X.2001.9705520

Arney, J.E., McGonigal, K.L., Ladner, B.C., and Wise, S.W., Jr., 2003. Lower Oligocene to middle Miocene diatom biostratigraphy of ODP Site 1140, Kerguelen Plateau. In Frey, F.A., Coffin, M.F., Wallace, P.J., and Quilty, P.G. (Eds.), Proceedings of the Ocean Drilling Program, Scientific Results, 183: College Station, TX (Ocean Drilling Program), 1-21. http://dx.doi.org/10.2973/odp.proc.sr.183.009.2003

Azpeitia Moros, F., 1911. La Diatomología Española en las Comienzos del Siglo XX: Madrid (Eduardo Arias Printing). (in Spanish) http://hdl.handle.net/2027/coo.31924000641658

Bailey, J.W., 1854. Notes on new species and localities of microscopical organisms. I. Fossil marine Diatomaceae in California. Smithsonian Contributions to Knowledge, 7(3):1-16.

Bailey, J.W., 1856. Notice of microscopic forms found in the soundings of the Sea of Kamtschatka. American Journal of Science Arts, 22(2):1-6.

Baldauf, J.G., and Barron, J.A., 1980. Actinocyclus ingens var. nodus: a new, stratigraphically useful diatom of the circum-North Pacific. Micropaleontology, 26(1):103-110. http://dx.doi.org/10.2307/1485279

Baldauf, J.G., and Barron, J.A., 1987. Oligocene marine diatoms recovered in dredge samples from the Navarin Basin Province, Bering Sea. U.S. Geological Survey Bulletin, 1765:1-17. http://pubs.er.usgs.gov/publication/b1765

Baldauf, J.G., and Barron, J.A., 1991. Diatom biostratigraphy: Kerguelen Plateau and Prydz Bay regions of the Southern Ocean. In Barron, J., Larsen, B., et al., Proceedings of the Ocean Drilling Program, Scientific Results, 119: College Station, TX (Ocean Drilling Program), 547-598. http://dx.doi.org/10.2973/odp.proc.sr.119.135.1991

Barron, J.A., 1975. Late Miocene-early Pliocene marine diatoms from southern California. Palaeontographica Abtelilung B: Palaeophytologie, 151:97-170.

Barron, J.A., and Mahood, A.D., 1993. Exceptionally wellpreserved early Oligocene diatoms from glacial sediments of Prydz Bay, East Antarctica. Micropaleontology, 39(1):29-45. http://dx.doi.org/10.2307/1485972

Bart, P.J., and Iwai, M., 2012. The overdeepening hypothesis: how erosional modification of the marine-scape 
during the early Pliocene altered glacial dynamics on the Antarctic Peninsula's Pacific margin. Palaeogeography, Palaeoclimatology, Palaeoecology. 335-336:42-51. http://dx.doi.org/10.1016/j.palaeo.2011.06.010

Bodén, P., 1993. Taxonomy and stratigraphic occurrence of Thalassiosira tetraoestrupii sp. nov. and related species in upper Miocene and lower Pliocene sediments from the Norwegian Sea, North Atlantic and northwest Pacific. Terra Nova, 5(1):61-75. http://dx.doi.org/10.1111/ j.1365-3121.1993.tb00227.x

Bohaty, S.M., Scherer, R.P., and Harwood, D.M., 1998. Quaternary diatom biostratigraphy and palaeoenvironments of the CRP-1 drillcore, Ross Sea, Antarctica. Terra Antartica, 5(3):431-453.

Bohaty, S.M., Wise, S.W., Jr., Duncan, R.A., Moore, C.L., and Wallace, P.J., 2003. Neogene diatom biostratigraphy, tephra stratigraphy, and chronology of ODP Hole 1138A, Kerguelen Plateau. In Frey, F.A., Coffin, M.F., Wallace, P.J., and Quilty, P.G. (Eds.), Proceedings of the Ocean Drilling Program, Scientific Results, 183: College Station, TX (Ocean Drilling Program), 1-53. http://dx.doi.org/10.2973/odp.proc.sr.183.016.2003

Brightwell, T., 1858. Remarks on the genus "Rhizosolenia" of Ehrenberg. Transactions of The Microscopical Society \& Journal, 6(1):93-95. http://dx.doi.org/10.1111/j.13652818.1858.tb04544.x

Brun, J., 1891. Diatomées: espéces nouvelles marines, fossiles ou pélagiques. Mémoires de la Société de Physique et d'Histoire Naturelle de Genève, 31:1-47.

Brun, J., 1894. Espéce nouvelles. Le Diatomiste, 2(16):8688.

Burckle, L.H., 1972. Late Cenozoic planktonic diatom zones from the eastern equatorial Pacific. In Simonsen, R. (Ed.), First Symposium on Recent and Fossil Marine Diatoms. Nova Hedwegia Beihefte, 39:217-246.

Cande, S.C., and Kent, D.V., 1995. Revised calibration of the geomagnetic polarity timescale for the Late Cretaceous and Cenozoic. Journal of Geophysical Research: Solid Earth, 100(B4):6093-6095.

http://dx.doi.org/10.1029/94JB03098

Castracane, C.A.F., 1886a. Report of the Scientific Results of the Voyage of HMS Challenger during the Years 18731876. Botany, 4.

Castracane, F., 1886b. Catalogo delle Diatomee rinvenute da D. Pantanelli nel calcare biancastro friable sovrapposto al bacino di lignite di Spoleto. Processi Verbali Societa Toscana di Scienze naturali di Pisa.

Censarek, B., and Gersonde, R., 2002. Miocene diatom biostratigraphy at ODP Sites 689, 690, 1088, 1092 (Atlantic sector of the Southern Ocean). Marine Micropaleontology, 45(3-4):309-356.

http://dx.doi.org/10.1016/S0377-8398(02)00034-8

Ciesielski, P.F., 1983. The Neogene and Quaternary diatom biostratigraphy of subantarctic sediments, Deep Sea Drilling Project Leg 71. In Ludwig, W.J., Krasheninnikov, V.A., et al., Initial Reports of the Deep Sea Drilling Project, 71: Washington, DC (U.S. Govt. Printing Office), 635-666.

http://dx.doi.org/10.2973/dsdp.proc.71.125.1983
Ciesielski, P.F., 1986. Middle Miocene to Quaternary diatom biostratigraphy of Deep Sea Drilling Project Site 594, Chatham Rise, southwest Pacific. In Kennett. J.P., von der Borch, C.C., et al., Initial Reports of the Deep Sea Drilling Project, 90: Washington, DC (U.S. Govt. Printing Office), 863-885.

http://dx.doi.org/10.2973/dsdp.proc.90.115.1986

Cleve, P.T., 1873. On diatoms from the Arctic Sea. Bihang Till Kongliga Svenska Vetenskaps-Akademiens Handlingar, 1(13).

http://hdl.handle.net/2027/uc1.31822032041238

Cleve, P.T., 1881. On some new and little known diatoms. Kongliga Svenska Vetenskaps-Akademiens Handlingar, 18(5). http://dx.doi.org/10.5962/bhl.title.2025

Cleve, P.T., and Grunow, A., 1880. Beiträge zur Kenntnis der arktischen Diatomeen. Kongliga Svenska VetenskapsAkademiens Handlingar, 17(2).

Cody, R.D., Levy, R.H., Harwood, D.M., and Sadler, P.M., 2008. Thinking outside the zone: high-resolution quantitative diatom biochronology for the Antarctic Neogene. Palaeogeography, Palaeoclimatology, Palaeoecology, 260(1-2):92-121. http://dx.doi.org/10.1016/j.palaeo.2007.08.020

Cortese, G., and Alvarez Zarikian, C.A., 2015. Data report: radiolarian occurrences at IODP Expedition 329 Site U1371. In D'Hondt, S., Inagaki, F., Alvarez Zarikian, C.A., and the Expedition 329 Scientists, Proceedings of the Integrated Ocean Drilling Program, 329: Tokyo (Integrated Ocean Drilling Program Management International, Inc.). dx.doi.org/10.2204/

iodp.proc.329.202.2015

Desikachary, T.V., Gowthaman, S., and Latha, Y., 1987. Diatom flora of some sediments from the Indian Ocean region. In Desikachary, T.V. (Ed.), Atlas of Diatoms (Vol. 2): Madras (Madras Science Foundation).

Desikachary, T.V., Latha, Y., and Ranjitha Devi, K.A., 1984. Rossiella and Bogorovia: two fossil diatom genera. The Palaeobotanist, 32:337-340.

Desikachary, T.V., and Sreelatha, P.M., 1989. Bibliotheca Diatomologica (Volume 19): Oamaru Diatoms: BerlinStuttgart (J. Cramer).

Dzinoridze, R.N., Jousé, A.P., Koroleva-Golikova, G.S., Kozlova, G.E., Nagaeva, G.S., Petrushevskaya, M.G., and Strelnikova, N.I., 1978. Diatom and radiolarian Cenozoic stratigraphy, Norwegian Basin; DSDP Leg 38. In Talwani, M., Udintsev, G., et al., Initial Reports of the Deep Sea Drilling Project, 38, 39, 40, 41 (Suppl.): Washington, DC (U.S. Govt. Printing Office), 289-427. http:// dx.doi.org/10.2973/dsdp.proc.38394041s.119.1978

Dzinoridze, R.N., Jousé, A.P., and Strelnikova, N.I., 1979. Description of diatoms. In Jousé, A.P. (Ed.), Explorations of the Faunas of the Seas (Volume 23): The History of the Microplankton of the Norwegian Sea (Based on DSDP Material): St. Petersburg, Russia (Academy of Science Russian Zoology Institute), 32-70.

Ehrenberg, C.G., 1837. Eine briefliche Nachricht des Hrn. Agassiz in Neuchatel über den ebenfalls aus mikroskopischen Kiesel-Organismen gebildeten Polirschiefer von Oran in Africa. Bericht über die zur Bekanntmachung gee- 
igneten Verhandlungen der Königlich Preussische Akademie der Wissenschaften zu Berlin, 1837:59-61.

Ehrenberg, C.G., 1838. Die Infusionsthierchen als vollkommene Organismen. Ein Blick in das tiefere organische Leben der Natur: Leipzig (Leopold Voss).

http://dx.doi.org/10.5962/bhl.title.58475

Ehrenberg, C.G., 1840a. Characteristik von 274 neuen Arten von Infusorien. Bericht über die zur Bekanntmachung geeigneten Verhandlungen der Königlich Preussische Akademie der Wissenschaften zu Berlin, 1840:197-219.

Ehrenberg, C.G., 1840b. Über noch jetzt zahlreich lebende Thierarten der Kreidebildung und den Organismus der Polythalamien. Abhandlungen Königlich Akademie der Wissenschaften zu Berlin: Berlin (Royal Academy of Sciences), 81-174.

Ehrenberg, C.G., 1843. Verbreitung und Einfluß des mikroskopischen Lebens in Süd- und Nord-Amerika: Berlin (Royal Academy of Sciences).

http://hdl.handle.net/2027/hvd.32044106423973.

Ehrenberg, C.G., 1844a. Einige vorläufige Resultate der Untersuchungen der von der Südpolreise des Captain Ross, sowie in den Herren Schayer und Darwin zugekommenen Materialien über das Verhalten des kleinsten Lebens in den Ozeanen und den größten bisher zugänglichen Tiefen des Weltmeeres. Bericht über die zur Bekanntmachung geeigneten Verhandlungen der Königlich Preussische Akademie der Wissenschaften zu Berlin, 1844:182-207.

Ehrenberg, C.G., 1844b. Mittheilung über zwei neue Lager von Gebirgsmassen aus Infusorien als Meeres-Absatz in Nord-Amerika und eine Vergleichung derselben mit den organischen Kreide-Gebilden in Europa und Afrika. Bericht über die zur Bekanntmachung geeigneten Verhandlungen der Königlich Preussische Akademie der Wissenschaften zu Berlin, 1844:57-97.

Ehrenberg, C.G., 1844c. Untersuchungen über die kleinsten Lebensformen im Quellenlande des Euphrats und Araxes, so wie über eine an neuen Formen sehr reiche marine Tripelbildung von den Bermuda-Inseln. Bericht über die zur Bekanntmachung geeigneten Verhandlungen der Königlich Preussischen Akademie der Wissenschaften zu Berlin, 1844(6):253-275. http://bibliothek.bbaw.de/ bibliothek-digital/digitalequellen/schriften/ anzeige?band=08-verh/1844\&seite:int=00000254

Ehrenberg, C.G., 1854. Mikrogeologie: Das Erden und Felsen schaffende Wirken des unsichtbar kleinen selbständigen Lebens auf der Erde: Leipzig (Verlag von Leopold Voss). http://gallica.bnf.fr/ark:/12148/bpt6k98694k

Expedition 329 Scientists, 2011. Site U1371. In D'Hondt, S., Inagaki, F., Alvarez Zarikian, C.A., and the Expedition 329 Scientists, Proceedings of the Integrated Ocean Drilling Program, 329: Tokyo (Integrated Ocean Drilling Program Management International, Inc.).

http://dx.doi.org/10.2204/iodp.proc.329.109.2011

Fenner, J., 1978. Cenozoic diatom biostratigraphy of the equatorial and southern Atlantic Ocean. In Perch-Nielsen, K., Supko, P.R., et al., Initial Reports of the Deep Sea Drilling Project, 38, 39, 40, 41 (Suppl.): Washington, DC (U.S. Govt. Printing Office), 491-624. http:// dx.doi.org/10.2973/dsdp.proc.38394041s.201.1978
Fenner, J., 1984. Eocene-Oligocene planktic diatom stratigraphy in the low latitudes and the high southern latitudes. Micropaleontology, 30(4):319-342. http://dx.doi.org/10.2307/1485708

Fenner, J., 1995. Siliceous microfossils in upper Neogene sediments from five guyots in the western North Pacific, with special emphasis on diatoms. In Haggerty, J.A., Premoli Silva, I., Rack, F., and McNutt, M.K. (Eds.), Proceedings of the Ocean Drilling Program, Scientific Results, 144: College Station, TX (Ocean Drilling Program), 61-85. http://dx.doi.org/10.2973/odp.proc.sr.144.006.1995

Fenner, J., Schrader, H.-J., and Wienigk, H., 1976. Diatom phytoplankton studies in the southern Pacific Ocean: composition and correlation to the Antarctic Convergence and its paleoecological significance. In Hollister, C.D., Craddock, C., et al., Initial Reports of the Deep Sea Drilling Project, 35: Washington, DC (U.S. Govt. Printing Office), 757-813.

http://dx.doi.org/10.2973/dsdp.proc.35.app3.1976

Fenner, J.M., 1991. Late Pliocene-Quaternary quantitative diatom stratigraphy in the Atlantic sector of the Southern Ocean. In Ciesielski, P.F., Kristoffersen, Y., et al., Proceedings of the Ocean Drilling Program, Scientific Results, 114: College Station, TX (Ocean Drilling Program), 97121.

http://dx.doi.org/10.2973/odp.proc.sr.114.133.1991

Forti, A., 1909. Studi per una Monografia del genere Pyxilla (Diatomee) e dei generi affini. Nuova Notarisia, 20:1938.

Forti, A., 1912. Primo elenco delle Diatomee fossili contenute nei calcari marnosi biancastri di Monte Gibbio (Sassuolo-Emilia). Nuova Notarisia, 23:79-84.

Forti, A., 1913. Contribuzioni diatomologiche. XIII. Diagnoses diatomacearum quarumdam fossilium italicarum. Atti del Reale Instituto Veneto di Scienze, Lettere ed Arti, 72(2):1535-1701.

Frenguelli, J., 1949. Diatomeas fósiles de los yacimientos chilenos de Tiltil y Mejillones. Darwiniana, 9(1):97-157. http://www.jstor.org/stable/23211723

Fryxell, G.A., 1977. Thalassiosira australis Peragallo and T. lentiginosa (Janisch) G. Fryxell, comb. nov.: two Antarctic diatoms (Bacillariophyceae). Phycologia, 16(1):95104. http://dx.doi.org/10.2216/i0031-8884-16-1-95.1

Fryxell, G.A., and Hasle, G.R., 1972. Thalassiosira eccentrica (Ehrenb.) Cleve, T. symmetrica sp. nov., and some related centric diatoms. Journal of Phycology, 8(4):297317. http://dx.doi.org/10.1111/j.15298817.1972.tb04044.x

Fryxell, G.A., Sims, P.A., and Watkins, T.P., 1986. Azpeitia (Bacillariophyceae): related genera and promorphology. Systematic Botany Monographs, 13:1-73.

Gersonde, R., 1980. Paläoökologische und biostratigraphische Auswertung von Diatomeenassoziationen aus dem Messinium des Caltanissettabeckens (Sizilien) und einiger Vergleichsprofile in SO-Spanien, NW-Algerien und auf Kreta [Dissertation]. Christian Albrechts Universität, Kiel, Germany.

Gersonde, R., 1990. Taxonomy and morphostructure of Neogene diatoms from the Southern Ocean, ODP Leg 113. In Barker, P.F., Kennett, J.P., et al., Proceedings of the 
Ocean Drilling Program, Scientific Results, 113: College Station, TX (Ocean Drilling Program), 791-802. http:// dx.doi.org/10.2973/odp.proc.sr.113.128.1990

Gersonde, R., 1991. Taxonomy and morphostructure of late Neogene diatoms from the Maude Rise (Antarctic Ocean). Polarforschung, 59(3):141-171. http:// epic.awi.de/28264/1/Polarforsch1989_3_4.pdf

Gersonde, R., and Bárcena, M.A., 1998. Revision of the upper Pliocene: Pleistocene diatom biostratigraphy for the northern belt of the Southern Ocean. Micropaleontology, 44(1):84-98. http://dx.doi.org/10.2307/1486086

Gersonde, R., and Burckle, L.H., 1990. Neogene diatom biostratigraphy of ODP Leg 113, Weddell Sea (Antarctic Ocean). In Barker, P.F., Kennett, J.P., et al., Proceedings of the Ocean Drilling Program, Scientific Results, 113: College Station, TX (Ocean Drilling Program), 761-789. http:// dx.doi.org/10.2973/odp.proc.sr.113.126.1990

Gladenkov, A.Y., 1998. Oligocene and lower Miocene diatom zonation in the North Pacific. Stratigraphy and Geological Correlation, 6(2):150-163.

Gladenkov, A.Y., 2003. Diatom biostratigraphy of the Neogene Milky River Formation, Alaska Peninsula, southwestern Alaska. Proceedings of the California Academy of Sciences, 54(3):27-64. http://researcharchive.calacademy.org/research/scipubs/pdfs/v54/proccas_v54_n03.pdf

Gleser, S.I., Jousé, A.P., Makarova, I.V., Proshkina-Lavrenko, A.I., and Sheshukova-Poretzkaya, V.S., 1974. The Diatoms of the USSR, Fossil and Recent, Volume 1: Leningrad, Russia (Nauka). (in Russian)

Gleser, S.I., Makarova, I.V., Moisseeva, A.I., and Nikolaev, V.A., 1988. The Diatoms of the USSR, Fossil and Recent. 2(1): Leningrad, Russia (Nauka). (in Russian)

Gleser, S.I., Makarova, I.V., Moisseeva, A.I., and Nikolaev, V., 1992. The Diatoms of the USSR, Fossil and Recent. 2(2): Leningrad, Russia (Nauka). (in Russian).

Gombos, A.M., Jr., 1977. Paleogene and Neogene diatoms from the Falkland Plateau and Malvinas Outer Basin: Leg 36, Deep Sea Drilling Project. In Barker, P.F., Dalziel, I.W.D., et al., Initial Reports of the Deep Sea Drilling Project, 36: Washington, DC (U.S. Govt. Printing Office), $575-687$.

http://dx.doi.org/10.2973/dsdp.proc.36.111.1977

Gombos, A.M., Jr., and Ciesielski, P.F., 1983. Late Eocene to early Miocene diatoms from the southwest Atlantic. In Ludwig, W.J., Krasheninnikov, V.A., et al., Initial Reports of the Deep Sea Drilling Project, 71: Washington, DC (U.S. Govt. Printing Office), 583-634. http://dx.doi.org/10.2973/dsdp.proc.71.124.1983

Gradstein, F.M., Ogg, J.G., and Smith, A. (Eds.), 2004. A Geologic Time Scale 2004: Cambridge, UK (Cambridge Univ. Press). http://dx.doi.org/10.2277/0521786738

Gran, H.H., 1897. Den Norske Nordhans-Expedition 18761878 (Volume 24): Protophyta: Diatomaceae, Silicoflagellata and Cilioflagellata: Christiania, Norway (Grøndahl \& Søn Forlag).

Gran, H.H., 1904. Diatomaceae from the ice-floes and plankton of the Arctic Ocean. In Nansen, F. (Ed.), The Norwegian North Polar Expedition 1893-1896 Scientific
Results: Christiania, Norway (Jacob Dybwad). http://hdl.handle.net/2027/hvd.32044106393671

Gregory, W., 1857. On new forms of marine Diatomaceae found in the Firth of Clyde and in Loch Fyne. Transactions of the Royal Society of Edinburgh, 21(4):473-542. http://dx.doi.org/10.1017/S0080456800032269

Grunow, A., 1862. Die österreichischen Diatomaceen nebst Anschluss einiger neuen Arten von andern Lokalitäten und einer kritischen Uebersicht der bisher bekannten Gattungen und Arten. Verhandlungen der zoologist-botanischen Gesellschaft in Wien, 12:315-588.

http://hdl.handle.net/2027/hvd.32044106394042

Grunow, A., 1863. Üeber einige neue und ungenügend bekannte Arten und Gattungen von Diatomaceen. Verhandlungen der kaiserlich-königlichen Zoologisch-botanischen Gesellschaft in Wien, 13:137-162. http:// www.biologiezentrum.at/pdf_frei_remote/VZBG_13_0137-0162.pdf

Grunow, A., 1868. Algae. In E. Fenzl (Ed.), Reise der Österreichischen Fregatte Novara um die Erde in den Jahren 1857, 1858, 1859. Botanischer Theil, Erster Band, Sporenpflanzen, 1:1-104. http://biodiversitylibrary.org/page/4279661

Grunow, A., 1884. Die diatomeen von Franz Josefs-Land. Denkschriften der Kaiserlichen Akademie der Wissenschaften der Wien, Mathematisch-Naturwissenschaftliche Classe, 48(2):53-112.

Hajós, M., 1968. Geologica Hungarica, Series Paleontologica (Volume 37): Die Diatomeen der Miozanen Ablagerungen des Matavvorlandes: Budapest (Muszaki Könyvkiadó).

Hajós, M., 1976. Upper Eocene and lower Oligocene diatomaceae, archaeomonadaceae, and silicoflagellatae in southwestern Pacific sediments, DSDP Leg 29. In Hollister, C.D., Craddock, C., et al., Initial Reports of the Deep Sea Drilling Project, 35: Washington, DC (U.S. Govt. Printing Office), 817-883. http://dx.doi.org/10.2973/ dsdp.proc.35.29chap1.1976

Hajós, M., 1986. Geologica Hungarica (Volume 49): Stratigraphy of Hungary's Miocene Diatomaceous Earth Deposits: Budapest (Muszaki Könyvkiadó).

Hajós, M., and Stradner, H., 1975. Late Cretaceous archaeomonadaceae, diatomaceae, and silicoflagellatae from the South Pacific Ocean, Deep Sea Drilling Project, Leg 29, Site 275. In Kennett, J.P., Houtz, R.E., et al., Initial Reports of the Deep Sea Drilling Project, 29: Washington, DC (U.S. Govt. Printing Office), 913-1009. http://dx.doi.org/10.2973/dsdp.proc.29.126.1975

Hanna, G.D., 1927. The lowest known Tertiary diatoms in California. Journal of Paleontology, 1(2):103-127. http://www.jstor.org/stable/1297922

Hanna, G.D., 1932. The diatoms of Sharktooth Hill, Kern Country, California. Proceedings of the California Academy of Sciences, Series 4, 20(6):161-263. http://biodiversitylibrary.org/page/3185691

Hanna, G.D., 1970. Fossil diatoms from the Pribilof Island, Bering Sea, Alaska. Proceedings of the California Academy of Sciences, Series 4, 37(5):167-234. http://biodiversitylibrary.org/page/15858920

Hanna, G.D., and Grant, W.M., 1926. Expedition to the Revillagigedo Islands, Mexico, in 1925, II. Miocene 
marine diatoms from Maria Madre Island, Mexico. Proceedings of the California Academy of Sciences, Series 4, 15(2):115-193. http://biostor.org/reference/78326

Hargraves, P.E., 1986. The relationship of some fossil diatom genera to resting spores. In Ricard, M. (Ed.), Proceedings of the International Diatom Symposium, 8:67-80.

Harwood, D.M., 1986. Diatoms. In Barrett, P.J. (Ed.), Antarctic Cenozoic History from the MSSTS-1 Drillhole, McMurdo Sound. DSIR Bulletin (New Zealand), 237:69107.

Harwood, D.M., and Bohaty, S.M., 2000. Marine diatom assemblages from Eocene and younger erratics, McMurdo Sound, Antarctica. In Stilwell, J.D., and Feldmann, R.M. (Eds.), Paleobiology and Paleoenvironments of Eocene Rocks, McMurdo Sound, East Antarctica. Antarctic Research Series, 76:73-98. http://onlinelibrary.wiley.com/doi/10.1029/AR076p0073/summary

Harwood, D.M., and Bohaty, S.M., 2001. Early Oligocene siliceous microfossil biostratigraphy of Cape Roberts Project Core CRP-3, Victoria Land Basin, Antarctica. Terra Antartica, 8(4):315-338.

Harwood, D.M., and Maruyama, T., 1992. Middle Eocene to Pleistocene diatom biostratigraphy of Southern Ocean sediments from the Kerguelen Plateau, Leg 120. In Wise, S.W., Jr., Schlich, R., et al., Proceedings of the Ocean Drilling Program, Scientific Results, 120: College Station, TX (Ocean Drilling Program), 683-733. http://dx.doi.org/10.2973/odp.proc.sr.120.160.1992

Harwood, D.M., McMinn, A., and Quilty, P.G., 2000. Diatom biostratigraphy and age of the Pliocene Sørsdal Formation, Vestfold Hills, East Antarctica. Antarctic Science, 12(4):443-462.

http://dx.doi.org/10.1017/S0954102000000535

Harwood, D.M., Scherer, R.P., and Webb, P.-N., 1989. Multiple Miocene marine productivity events in West Antarctica as recorded in upper Miocene sediments beneath the Ross Ice Shelf (Site J-9). Marine Micropaleontology, 15(1-2):91-115.

http://dx.doi.org/10.1016/0377-8398(89)90006-6

Hasegawa, Y., 1977. Late Miocene diatoms from the Nakayama Formation in the Sado Island, Niigata Prefecture, Japan. Publications from the Sado Museum, 7:77101. (in Japanese with English abstract)

Hasle, G.R., 1960. Phytoplankton and ciliate species from the tropical Pacific. Skrifter utgitt av det Norske Videnskaps-Akademi i Oslo: Matematisk-Naturvidenskapelig Klasse, 2.

Hasle, G.R., 1965. Nitzschia and Fragilariopsis species in the light and electron microscopes. III. The genus Fragilariopsis. Skrifter utgitt av det Norske Videnskaps-Akademi of Oslo: Matematisk-Naturvidenskapelig Klasse, 21.

Hasle, G.R., 1972a. Fragilariopsis Hustedt as a section of the genus Nitzschia Hassall. Nova Hedwigia, 39:111-120.

Hasle, G.R., 1972b. The inclusion of Coscinosira Gran (Bacillariophyceae) in Thalassiosira Cleve. Taxon, 21(4):543-544. http://dx.doi.org/10.2307/1219143

Hasle, G.R., Heimdal, B.R., and Fryxell, G.A., 1971. Morphologic variability in fasciculated diatoms as exemplified by Thalassiosira tumida (Janisch) Hasle, comb. nov. In Llano, G.A., and Wallen, I.E. (Eds.), Biology of the Ant- arctic Seas IV. Antarctica Research Series, 17:313-333. http://onlinelibrary.wiley.com/doi/10.1029/ AR017p0313/summary

Hasle, G.R., Medlin, L.K., and Syvertsen, E.E., 1994. Synedropsis gen. nov., a genus of araphid diatoms associated with sea ice. Phycologia, 33(4):248-270.

http://dx.doi.org/10.2216/i0031-8884-33-4-248.1

Hasle, G.R., and Syvertsen, E.E., 1990. Family Biddulphiaceae. In Medlin, L.K., and Priddle, J. (Eds.), Polar Marine Diatoms: Cambridge, UK (British Antarctic Survey), 129131.

Heiden, H., and Kolbe, R.W., 1928. Die Marinen Diatomeen der Deutschen Südpolar-Expedition 1901-1903. In von Drygalski, E. (Ed.), Deutsche Südpolar-Expedition, 1901-1903: Berlin (W. de Gruyter), 8:447-715.

Homann, M., 1991. Die diatomeen der Fur-Formation (Alttertiär, Limfjord/Dänemark). Geologisches Jahrbuch Reihe A, 123.

Houk, V., and Klee, R., 2004. The stelligeroid taxa of the genus Cyclotella (Kützing) Brébisson (Bacillariophyceae) and their transfer into the new genus Discostella gen. nov. Diatom Research, 19(2):203-228. http://dx.doi.org/10.1080/0269249X.2004.9705871

Hustedt, F., 1927-1930. Kryptogamen-Flora von Deutschland, Österreich und der Schweiz (Volume 7): Die Kieselalgen Deutschland, Österreichs und der Schweiz unter Berücksichtigung der übrigen länder Europas sowie der angrenzenden meeresgebiete. Rabenhorst, L. (Series Ed.): Koenigstein (O. Koeltz Science Publishers).

Hustedt, F., 1952. Diatomeen aus der Lebensgemeinschaft der Buckelwals (Megaptera nodosa Bonn.). Archives of Hydrobiology, 46(2):286-298.

Hustedt, F., 1958. Diatomeen aus der Antarktis und dem Südatlantik. Deutsche Antarktische Expedition 1938/1939: Hamburg (Geographisch-Kartographische Anstalt Mundus), 2:103-191.

Iwai, M., and Winter, D., 2002. Data report: taxonomic notes of Neogene diatoms from the western Antarctic peninsula: Ocean Drilling Program Leg 178. In Barker, P.F., Camerlenghi, A., Acton, G.D., and Ramsay, A.T.S. (Eds.), Proceedings of the Ocean Drilling Program, Scientific Results, 178: College Station, TX (Ocean Drilling Program), 1-57. http://dx.doi.org/10.2973/odp.proc.sr.178.239.2002

Jordan, R.W., and Priddle, J., 1991. Fossil members of the diatom genus Proboscia. Diatom Research, 6(1):55-61. http://dx.doi.org/10.1080/0269249X.1991.9705147

Jousé, A.P., 1959. The main phases in the development of the flora of marine diatoms in the far eastern seas of the U.S.S.R. at the end of the Tertiary, and during the Quaternary period. Botanicheskii Zhurnal (Sankt-Petersburg, Russian Federation), 44(1):44-55.

Jousé, A.P., 1963. Type Bacillariophyta. Diatom algae. In Vakhrameev, V.A., Radchenko, G.P., and Takhtadzhan, A.L. (Eds.), The Foundations of Paleontology. Guide for Paleontologists and Geologists of the USSR: Moscow (Russian Academy of Sciences Press), 14:55-124. (in Russian)

Jousé, A.P., 1968. New species of diatoms in bottom sediment of the Pacific and the Sea of Okhotsk. Nov. Sys- 
temat. Plant. Non. Vascular., Akademiya Nauk SSSR, 3:1221.

Jousé, A.P., 1977. Atlas of microorganisms in bottom sediments of the oceans (Diatoms, Radiolaria, Silicoflagellates and Coccoliths): Moscow (Nauka). (in Russian)

Jousé, A.P., Koroleva, G.S., and Nagaeva, G.A., 1962. Diatoms in the surface layer of sediment in the Indian sector of the Antarctic. Trudy-Akademiya Nauk SSSR, Oceanologia Institut, 61:20-91.

Kanaya, T., 1957. Eocene diatom assemblages from the Kellogg and "Sidney" shales, Mt. Diablo area, California. Science Report of the Tohoku University, Series 2: Geology, 28. http://ci.nii.ac.jp/naid/110004652731/en

Kanaya, T., 1959. Miocene diatom assemblages from the Onnagawa Formation and their distribution in correlative formations in northeast Japan. Science Report of the Tohoku University, Series 2: Geology, 30. http://ci.nii.ac.jp/naid/110004652735

Kanaya, T., and Koizumi, I., 1970. The progress in the younger Cenozoic diatom biostratigraphy in the northern circum-Pacific Region. Journal of Marine Geology, 6(2):47-66. (in Japanese)

Karsten, G., 1905. Das Phytoplankton des Antarktischen Meeres. In Chun, C. (Ed.), Wissenschaftliche Ergebnisse der Deutschen Tiefsee-Expedition auf dem Dampfer "Valdivia" 1898-1899 (Volume 2): Jena (Gustav Fischer).

Kim, W.H., and Barron, J.A., 1986. Diatom biostratigraphy of the upper Oligocene to lowermost Miocene San Gregorio Formation, Baja California Sur, Mexico. Diatom Research, 1(2):169-187. http://dx.doi.org/10.1080/0269249X.1986.970496

Koizumi, I., 1968. Tertiary diatom flora of Oga Peninsula, Akita Prefecture, Northeast Japan. The Science Reports of the Tohoku University, Series 2: Geology, 40(3):171-240. http://ci.nii.ac.jp/naid/110004646813

Koizumi, I., 1982. Late Quaternary diatoms of the Bellingshausen Basin, Antarctic Ocean. Representative Technical Research, Central Japanese National Oil Corporation, 16:75-90.

Kützing, F.T., 1844. Die kieselschaligen Bacillarien oder Diatomeen: Nordhausen (W. Köhne).

Lee, Y.G., 1986. Micropaleontological study of Neogene strata of southeastern Korea and adjacent sea floor. Journal of the Paleontological Society of Korea, 2(2):83-113. http://www.dbpia.co.kr/Article/1219528

Lee, Y.G., 1993. The marine diatom genus Chaetoceros Ehrenberg flora and some resting spores of the Neogene Yeonil Group in the Pohang Basin, Korea. Korea Journal of Paleontology, 9(1):24-52.

Lohman, K.E., 1948. Middle Miocene diatoms from the Hammond Well: Cretaceous and Tertiary subsurface geology. Maryland, Department of Geology, Mines and Water Resources, Bulletin, 2:151-187.

Lohman, K.E., 1974. Lower middle Miocene marine diatoms from Trinidad. Verhandlungen der Naturforschenden Gesellschaft in Basel, 84(1):326-360.

Mahood, A.D., and Barron, J.A., 1995. Thalassiosira tetraoestrupii var. reimeri var. nov., a distinctive diatom from the late Pliocene of the Southern Ocean. In Kociolek, J.P., and Sullivan, M.J. (Eds.), A Century of Diatom Research in North America: A Tribute to the Distinguished Careers of Charles Reimer and Ruth Patrick: Champaign, IL (Koeltz Scientific Books USA), 1-8.

Mahood, A.D., and Barron, J.A., 1996a. Comparative ultrastructure of two closely related Thalassiosira species: Thalassiosira vulnifica (Gombos) Fenner and T. fasciculata Harwood et Maruyama. Diatom Research, 11(2):283295.

http://dx.doi.org/10.1080/0269249X.1996.9705385

Mahood, A.D., and Barron, J.A., 1996b. Late Pliocene diatoms in a diatomite from Prydz Bay, East Antarctica. Micropaleontology, 42(3):285-302.

http://dx.doi.org/10.2307/1485876

Makarova, I.V., 1962. Ad cognitionem sporarum fossilium specierum generis Chaetoceros Ehr. Notulae Systematicae e Sectione Cryptogamica Instituti Botanici Nomine V.L. Komarovii Academiae Scientiarium USSR, 15:41-57. (in Russian)

Makarova, I.V., and Nikolaev, V.A., 1984. Notes on the Genus Schimperiella (Bacillariophyta). Botanicheskii Zhunal, Academii Nauk USSR, 69:87-90. (in Russian)

Mangin, L., 1915. Phytoplankton de l'Antarctique. Expédition du "Pourquoi-Pas?" 1908-1910. Deuxième Expédition Antarctique Francaise (1908-1910): Sciences naturelles: Documents scientifiques, 2.

Manguin, P.E., 1957. Premier inventaire de Diatomées de la Terre Adélie Antarctique: espèces nouvelles. Revue Algologique Nouvelle Série, 3:111-134.

Maruyama, T., 1984. Miocene diatom biostratigraphy of onshore sequences on the Pacific side of Northeast Japan, with reference to DSDP Hole 438A (Part 1). Science Reports of the Tohoku University, Series 2: Geology, 55(1):77-140. http://hdl.handle.net/10097/28851

McCollum, D.W., 1975. Diatom stratigraphy of the Southern Ocean. In Hayes, D.E., Frakes, L.A., et al., Initial Reports of the Deep Sea Drilling Project, 28: Washington, DC (U.S. Govt. Printing Office), 515-571. http://dx.doi.org/10.2973/dsdp.proc.28.112.1975

Medlin, L.K., and Sims, P.A., 1993. The transfer of Pseudoeunotia doliolus to Fragilariopsis. Nova Hedwigia, 106:323-334.

Mereschkowsky, C., 1889. Note on diatoms from Chincha guano. Annals and Magazine of Natural History: Series 7, 6(35):481-489. http://dx.doi.org/10.1080/00222930008678413

Mereschkowsky, C., 1902. Liste des Diatomées de la mer Noire: St. Petersburg (Scripta Botanica), 19:51-88. (in Russian)

Ogg, J.G., and Smith, A.G., 2004. The geomagnetic polarity time scale. In Gradstein, F., Ogg, J., and Smith, A. (Eds.), A Geologic Time Scale 2004: Cambridge, UK (Cambridge University. Press), 63-86. http://dx.doi.org/10.1017/СВ09780511536045.006

O'Meara, E., 1877. On the diatomaceous gatherings made at Kerguelen's Land by H. N. Moseley, M.A.: H.M.S. Challenger. Journal of the Linnean Society of London, Botany, 15(82):55-63. 
Ostenfeld, C.H., 1900. Plankton in 1899. In Wandel, C.F., Knudsen, M., and Ostenfeld, C.H. (Eds.), Iagttagelser over Overfladevandets Temperatur, Saltholdighed og Plankton paa islandske og grønlandske Skibsrouter i 1899: Kobenhavn (I. Kommission hos G.E.C. Gad.), 43-93.

Pantocsek, J., 1886. Beiträge zur Kenntnis der Fossilen Bacillarien Ungarns (Bd. 1): Marine Bacillarien: Berlin (W. Junk). (in German)

Pantocsek, J., 1903. Beiträge zur Kenntnis der Fossilen Bacillarien Ungarns. 1. Theil: Marine Bacillarien: Berlin (W. Junk). (in German)

Pritchard, A., 1861. A History of Infusoria, including the Desmidiaceoe and Diatomacoe, British and Foreign (4th edition): London (Whittaker and Co.).

Proschkina-Lavrenko, A.I., 1949. Diatom Analysis: Handbook of Fossil and Recent Diatoms, Order Centrales. Botanicheskií Institut, V.L. Komarova, Akademie Nauk SSSR. (in Russian)

Rattray, J., 1890a. A revision of the genus Actinocyclus, Ehrb: London (Journal of the Quekett Microscopical Club), 4:137-212.

Rattray, J., 1890b. A revision of the genus Coscinodiscus, Ehrb., and some allied genera. Proceedings of the Royal Society of Edinburgh, 16:449-692.

Rines, J.E.B., and Hargraves, P.E., 1988. The Chaetoceros Ehrenberg (Bacillariophyceae) flora of Narrangansett Bay, Rhode Island, U.S.A. Bibliotheca Phycologica, 79.

Round, F.E., Crawford, R.M., and Mann, D.G., 1990. The Diatoms: Biology and Morphology of the Genera: Cambridge, UK (Cambridge University Press).

Sancetta, C., 1982. Distribution of diatom species in surface sediments of the Bering and Okhotsk Seas. Micropaleontology, 28(3):221-257. http://dx.doi.org/10.2307/1485181

Sanfilippo, A., and Fourtanier, E., 2003. Oligocene radiolarians, diatoms, and ebridians from the Great Australian Bight (ODP Leg 182, Site 1128). In Hine, A.C., Feary, D.A., and Malone, M.J. (Eds.), Proceedings of the Ocean Drilling Program, Scientific Results, 182: College Station, TX (Ocean Drilling Program), 1-24. http://dx.doi.org/10.2973/odp.proc.sr.182.004.2003

Scherer, R.P., and Koç, N., 1996. Late Paleogene diatom biostratigraphy and paleoenvironments of the northern Norwegian-Greenland Sea. In Thiede, J., Myhre, A.M., Firth, J.V., Johnson, G.L., and Ruddiman, W.F. (Eds.), Proceedings of the Ocean Drilling Program, Scientific Results, 151: College Station, TX (Ocean Drilling Program), 75-99. http://dx.doi.org/10.2973/odp.proc.sr.151.155.1996

Schmidt, A., 1874-1959. Atlas der Diatomaceenkunde: Leipzig (O.R. Reisland). http://dx.doi.org/10.5962/bhl.title.64396

Schrader, H.-J., 1973. Cenozoic diatoms from the northeast Pacific, Leg 18. In Kulm, L.D., von Huene, R., et al., Initial Reports of the Deep Sea Drilling Project, 18: Washington, DC (U.S. Govt. Printing Office), 673-797. http://dx.doi.org/10.2973/dsdp.proc.18.117.1973

Schrader, H.-J., 1976. Cenozoic planktonic diatom biostratigraphy of the southern Pacific Ocean. In Hollister, C.D., Craddock, C., et al., Initial Reports of the Deep Sea
Drilling Project, 35: Washington, DC (U.S. Govt. Printing Office), 605-671.

http://dx.doi.org/10.2973/dsdp.proc.35.136.1976

Schrader, H.-J., and Fenner, J., 1976. Norwegian Sea Cenozoic diatom biostratigraphy and taxonomy. In Talwani, M., Udintsev, G., et al., Initial Reports of the Deep Sea Drilling Project, 38: Washington, DC (U.S. Govt. Printing Office), 921-1099.

http://dx.doi.org/10.2973/dsdp.proc.38.130.1976

Schrader, H.-J., and Schuette, G., 1981. Marine diatoms. In Emiliani, C. (Ed.), The Sea (Vol. 7): New York (Wiley), 1179-1232.

Schumann, J., 1867. Preussische diatomeen. Schriften der Koniglichen Physikalisch-Ökonomischen Gesellschaft zu Königsberg, 1-58. http://dx.doi.org/10.5962/bhl.title.64247

Sheshukova-Poretzkaya, V.S., 1959. On fossil diatom flora of South Sakhaline (Marine Neogene). Bulletin of the Leningrad Gos. University, Biology Series, 15:36-55. (in Russian, with abstract in English)

Sheshukova-Poretzkaya, V.S., 1962. New and rare Bacillariophyta from diatom series of Sakhalin Island. Uchenye Zapiski-Igu. Ser. Biol. Nauk (Leningrad University), 49:203-211.

Sheshukova-Poretzkaya, V.S., 1967. Neogene Marine Diatoms of Sakhalin and Kamchatka: Leningrad, Russia (Leningrad University Press), 8. (in Russian)

Shirshov, P.P., 1977. Atlas of Microorganisms in Bottom Sediments of the Oceans (Volume 32): Moscow (Nauka).

Simonsen, R., 1979. The diatom system: ideas on phylogeny. Bacillaria, 2:9-66.

Simonsen, R., 1982. Notes on the diatom genus Charcotia M. Peragallo. Bacillaria, 5:101-116.

Smith, W.H.F., and Sandwell, D.T., 1997. Global seafloor topography from satellite altimetry and ship depth soundings. Science, 277(5334):1956-1962. http://dx.doi.org/10.1126/science.277.5334.1956

Sournia, A., Grall, J.-R., and Jacques, G., 1979. Diatomées et Dinoflagellés planctoniques d'une coupe méridienne dans le sud de l'océan Indien (campagne Antipod I du Marion DuFresne, mars 1977). Botanica Marina, 22:183198. http://dx.doi.org/10.1515/botm.1979.22.3.183

Stockwell, D.A., 1991. Distribution of Chaetoceros resting spores in the Quaternary sediments from Leg 119. In Barron, J., Larsen, B., et al., Proceedings of the Ocean Drilling Program, Scientific Results, 119: College Station, TX (Ocean Drilling Program), 599-610. http://dx.doi.org/10.2973/odp.proc.sr.119.156.1991

Strelnikova, N.I., 1974. Diatoms of the Late Cretaceous: Moscow (Nauka). (in Russian)

Sundström, B.G., 1986. The marine diatom genus Rhizosolenia-a new approach to the taxonomy [Ph.D. thesis]. Lund University, Sweden.

Suto, I., 2003. Taxonomy of the marine diatom resting spore genera Dicladia Ehrenberg, Monocladia gen. nov. and Syndendrium Ehrenberg and their stratigraphic significance in Miocene strata. Diatom Research, 18(2):331356.

http://dx.doi.org/10.1080/0269249X.2003.9705596 
Suto, I., 2004a. Coronodiscus gen. nov., a new diatom resting spore genus from the North Pacific and Norwegian Sea. Diatom, 20:95-104.

http://dx.doi.org/10.11464/diatom1985.20.0_95

Suto, I., 2004b. Dispinodiscus gen. nov., a new diatom resting spore genus from the North Pacific and Norwegian Sea. Diatom, 20:79-94.

http://doi.org/10.11464/diatom1985.20.0_79

Suto, I., 2004c. Fossil marine diatom resting spore morphogenus Gemellodiscus gen. nov. in the North Pacific and Norwegian Sea. Paleontological Research, 8(4):255-282. http://dx.doi.org/10.2517/prpsj.8.255

Suto, I., 2004d. Fossil marine diatom resting spore morpho-genus Xanthiopyxis Ehrenberg in the North Pacific and Norwegian Sea. Paleontological Research, 8(4):283310. http://dx.doi.org/10.2517/prpsj.8.283

Suto, I., 2004e. Taxonomy of the diatom resting spore form genus Liradiscus Greville and its stratigraphic significance. Micropaleontology, 50(1):59-79. http://dx.doi.org/10.2113/50.1.59

Suto, I., 2005a. Taxonomy and biostratigraphy of the fossil marine diatom resting spore genera Dicladia Ehrenberg, Monocladia Suto and Syndendrium Ehrenberg in the North Pacific and Norwegian Sea. Diatom Research, 20(2):351-374. http://dx.doi.org/10.1080/0269249X.2005.9705642

Suto, I., 2005b. Vallodiscus gen. nov., a new fossil resting spore morpho-genus related to the marine diatom genus Chaetoceros (Bacillariophyceae). Paleontological Research, 53(1):11-29.

http://dx.doi.org/10.1111/j.1440-183.2005.00369.x

Suto, I., 2006a. Taxonomy of the fossil marine diatom resting spore morpho-genera Xanthioisthmus Suto gen. nov. and Quadrocistella Suto gen. nov. in the North Pacific and Norwegian Sea. J. Micropaleontology, 25(1):3-22. http://dx.doi.org/10.1144/jm.25.1.3

Suto, I., 2006b. The explosive diversification of the diatom genus Chaetoceros across the Eocene/Oligocene and Oligocene/Miocene boundaries in the Norwegian Sea. Marine Micropaleontology, 58(4):259-269. http://dx.doi.org/10.1016/j.marmicro.2005.11.004

Suto, I., 2006c. Truncatulus gen. nov., a new fossil resting spore morphogenus related to the marine diatom genus Chaetoceros (Bacillariophyceae). Phycologia, 45(5):581601. http://dx.doi.org/10.2216/04-91.1

Suto, I., 2007. The Oligocene and Miocene record of the diatom resting spore genus Liradiscus Greville in the Norwegian Sea. Micropaleontology, 53(1-2):145-159. http://dx.doi.org/10.2113/gsmicropal.53.1-2.145

Suto, I., Jordan, R.W., and Watanabe, M., 2008. Taxonomy of the fossil marine diatom resting spore genus Goniothecium Ehrenberg and its allied species. Diatom Research, 23(2):445-469. http://dx.doi.org/10.1080/0269249X.2008.9705769

Suto, I., Jordan, R.W., and Watanabe, M., 2009. Taxonomy of middle Eocene diatom resting spores and their allied taxa from the Central Arctic Basin. Micropaleontology, 55(2-3):259-312.

http://www.jstor.org/stable/40607116
Suto, I., Kawamura, K., and Chiyonobu, S., 2013. Data report: Pliocene and Pleistocene diatom floras and taxonomic notes from the Canterbury Basin (IODP Expedition 317 Hole U1352B), off New Zealand. In Fulthorpe, C.S., Hoyanagi, K., Blum, P., and the Expedition 317 Scientists, Proceedings of the Integrated Ocean Drilling Program, 317: Tokyo (Integrated Ocean Drilling Program Management International, Inc.). http://dx.doi.org/10.2204/iodp.proc.317.202.2013

Suto, I., Kawamura, K., Hagimoto, S., Teraishi, A., and Tanaka, Y., 2012. Changes in upwelling mechanisms drove the evolution of marine organisms. Palaeogeography, Palaeoclimatology, Palaeoecology, 339-341:39-51. http://dx.doi.org/10.1016/j.palaeo.2012.04.014

Takahashi, M., Suto, I., Ohki, J., and Yanagisawa, Y., 2003. Chronostratigraphy of the Miocene Series in the Choshi area, Chiba Prefecture, central Japan. Journal of the Geological Society of Japan, 109(6):345-360. (in Japanese with English abstract). http://doi.org/10.5575/geosoc.109.345

Tanimura, Y., 1992. Distribution of diatom species in the surface sediments of Lützow-Holm Bay, Antarctica. In Ishizaki, K., and Saito, T. (Eds.), Centenary of Japanese Micropaleontology: Tokyo (Terra Scientific Publishing Company), 399-411. http://www.terrapub.co.jp/elibrary/cjm/pdf/0399.pdf

Tanimura, Y., Shimada, C., and Iwai, M. 2007. Modern distribution of Thalassionema species (Bacillariophyceae) in the Pacific Ocean. Bulletin of the National Museum of Nature and Science, Series C, 33:27-51.

http://ci.nii.ac.jp/

lognavi? name $=$ nels $\&$ lang $=$ en $\&$ type $=$ pdf\&id $=$ ART000 9202210

Tempère, J., and Peragallo, H., 1915. Diatomées du Monde Entier (2nd edition): Gironde (J. Tempère, Arcachon). http://hdl.handle.net/2027/coo.31924000653612

Tsoy, I.B., 2003. Eocene diatoms and silicoflagellates from the Kronotskii Bay deposits (East Kamchatka). Stratigraphy and Geological Correlation, 11(4):376-390.

Van Heurck, H., 1880-1881. Synopsis des Diatomées de Belgique: Atlas: Anvers (Édité par L'auteur).

Van Heurck, H., 1885. Synopsis des Diatomées de Belgique: Texte: Anvers (Édité par L'auteur). http://dx.doi.org/10.5962/bhl.title.1990

Van Heurck, H., 1896. A Treatise on the Diatomaceae: London (William Wesley \& Son). http://dx.doi.org/10.5962/bhl.title.2002

Van Heurck, H.F., 1909. Diatomées. In Expédition Antarctique Belge: Résultats du Voyage du S.Y. Belgica en 18971898-1899: Botaniques: Anvers (J.E. Buschmann).

Wallich, G.C., 1860. On the siliceous organisms found in the digestive cavities of the Salpae, and their relation to the flint nodules of the Chalk Formation. Transactions of the Microscopical Society of London, 8(1):36-55. http:// dx.doi.org/10.1111/j.1365-2818.1860.tb01241.x

Whiting, M.C., and Schrader, H., 1985a. Actinocyclus ingens Rattray: reinvestigation of a polymorphic species. Micropaleontology, 31(1):68-75. http://dx.doi.org/10.2307/1485582 
Whiting, M.C., and Schrader, H., 1985b. Late Miocene to early Pliocene marine diatom and silicoflagellate floras from the Oregon coast and continental shelf. Micropaleontology, 31(3):249-270.

http://dx.doi.org/10.2307/1485544

Williams, D.M., 1989. Cavitatus D. M. Williams nov. gen.: a new genus of fossil diatom (Bacillariophyta) based on Synedra jouseana Sheshukova-Poretskaya. Review of Palaeobotany and Palynology, 58(2-4):357-362. http://dx.doi.org/10.1016/0034-6667(89)90092-4

Winter, D., 2001. Data report: diatom biostratigraphic data and plates from ODP Leg 172, Hole 1063D, with brief discussion of present ecological affinities of taxa. In Keigwin, L.D., Rio, D., Acton, G.D., and Arnold, E. (Eds.), Proceedings of the Ocean Drilling Program, Scientific Results, 172: College Station, TX (Ocean Drilling Program), 1-49.

http://dx.doi.org/10.2973/odp.proc.sr.172.202.2001

Wornardt, W.W., Jr., 1967. Miocene and Pliocene marine diatoms from California. Occasional Papers of the California Academy of Sciences, 63.

Yanagisawa, Y., 1994a. Koizumia Yanagisawa gen. nov., a new marine fossil araphid diatom genus. Transactions and Proceedings of the Palaeontological Society of Japan, New Series, 176:591-617. https://www.jstage.jst.go.jp/ article/prpsj1951/1994/176/1994_176_591/_pdf

Yanagisawa, Y., 1994b. Mediaria magna Yanagisawa, sp. nov., a new fossil raphid diatom species useful for mid- dle Miocene diatom biostratigraphy. Transactions and Proceedings of the Palaeontological Society of Japan, New Series, 174:411-425.

Yanagisawa, Y., 1995. Cenozoic diatom genus Bogorovia Jousé: an emended description. Transactions and Proceedings of the Palaeontological Society of Japan, New Series, 177:21-42. https://www.jstage.jst.go.jp/article/ prpsj1951/1995/177/1995_177_21/_pdf

Yanagisawa, Y., and Akiba, F., 1990. Taxonomy and phylogeny of the three marine diatom genera, Crucidenticula, Denticulopsis and Neodenticula. Bulletin of the Geological Survey of Japan, 41(5):197-301.

Zielinski, U., Bianchi, C., Gersonde, R., and Kunz-Pirrung, M., 2002. Last occurrence datums of the diatoms Rouxia leventerae and $R$. constricta: indicators for marine isotope Stages 6 and 8 in Southern Ocean sediments. Marine Micropaleontology, 46(1-2):127-137. http://dx.doi.org/10.1016/S0377-8398(02)00042-7

Zielinski, U., and Gersonde, R., 2002. Plio-Pleistocene diatom biostratigraphy from ODP Leg 177, Atlantic sector of the Southern Ocean. Marine Micropaleontology, 45(34):225-268. http://dx.doi.org/10.1016/S0377-8398(02)00031-2

Initial receipt: 24 February 2014

Acceptance: 16 June 2015

Publication: 10 November 2015

MS 329-203 
Figure F1. South Pacific seafloor bathymetry map (Smith and Sandwell, 1997) illustrating tectonic setting and Expedition 329 sites. Site U1371 $\left(45^{\circ} 58^{\prime} \mathrm{S}, 163^{\circ} 11^{\prime} \mathrm{W}\right.$, water depth $\left.=5310 \mathrm{~m}\right)$ is located at the southern end of the southwestern transect. White lines = basement age in $10 \mathrm{~m}$.y. increments. DSDP = Deep Sea Drilling Project, ODP $=$ Ocean Drilling Program.

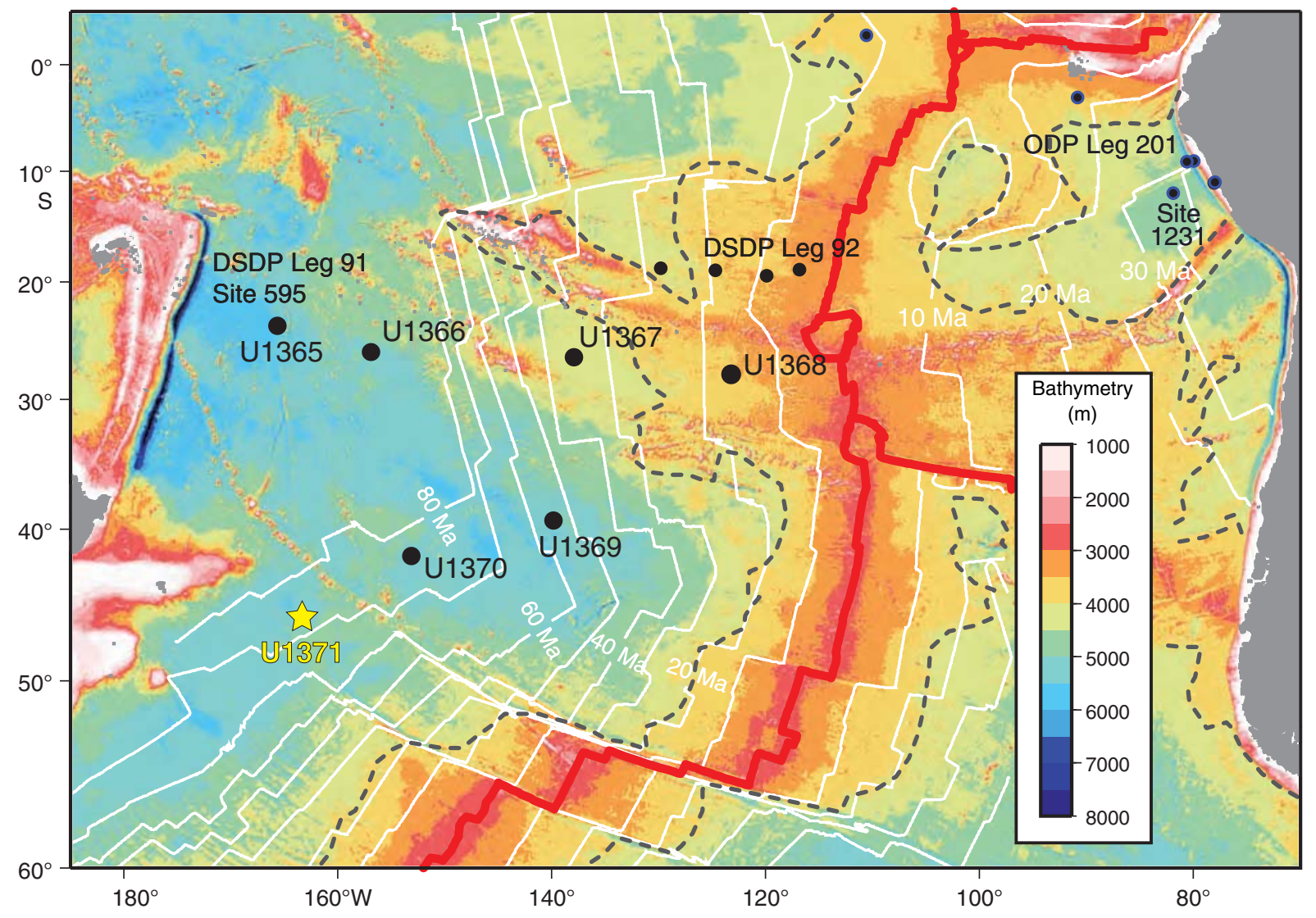


Figure F2. Stratigraphic distribution of selected diatom taxa, Hole U1371D. Note that the abundances of Fragilariopsis kerguelensis and Chaetoceros resting spores are compressed in width. Polarity after the shipboard results in Expedition 329 Scientists (2011). Chron boundary ages after the geomagnetic polarity timescale of Ogg and Smith (2004).

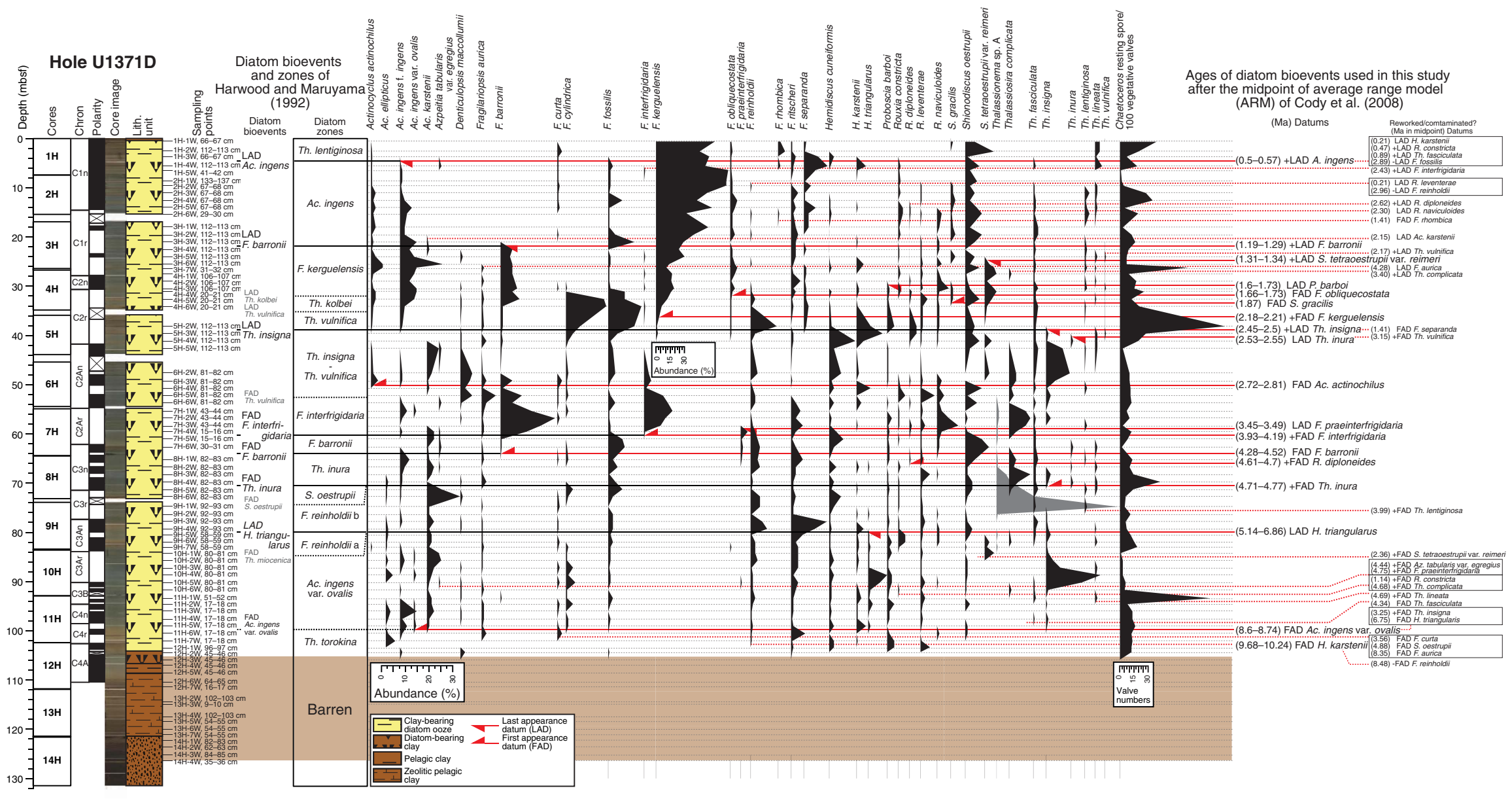


Figure F3. Age-depth plot, Hole U1371D. Ages of diatom bioevents are used after the midpoint of average range model of Cody et al. (2008). Polarity after the shipboard results in Expedition 329 Scientists (2011). Chron boundary ages after the geomagnetic polarity timescale of Ogg and Smith (2004).

Hole U1371D Diatom bioevents

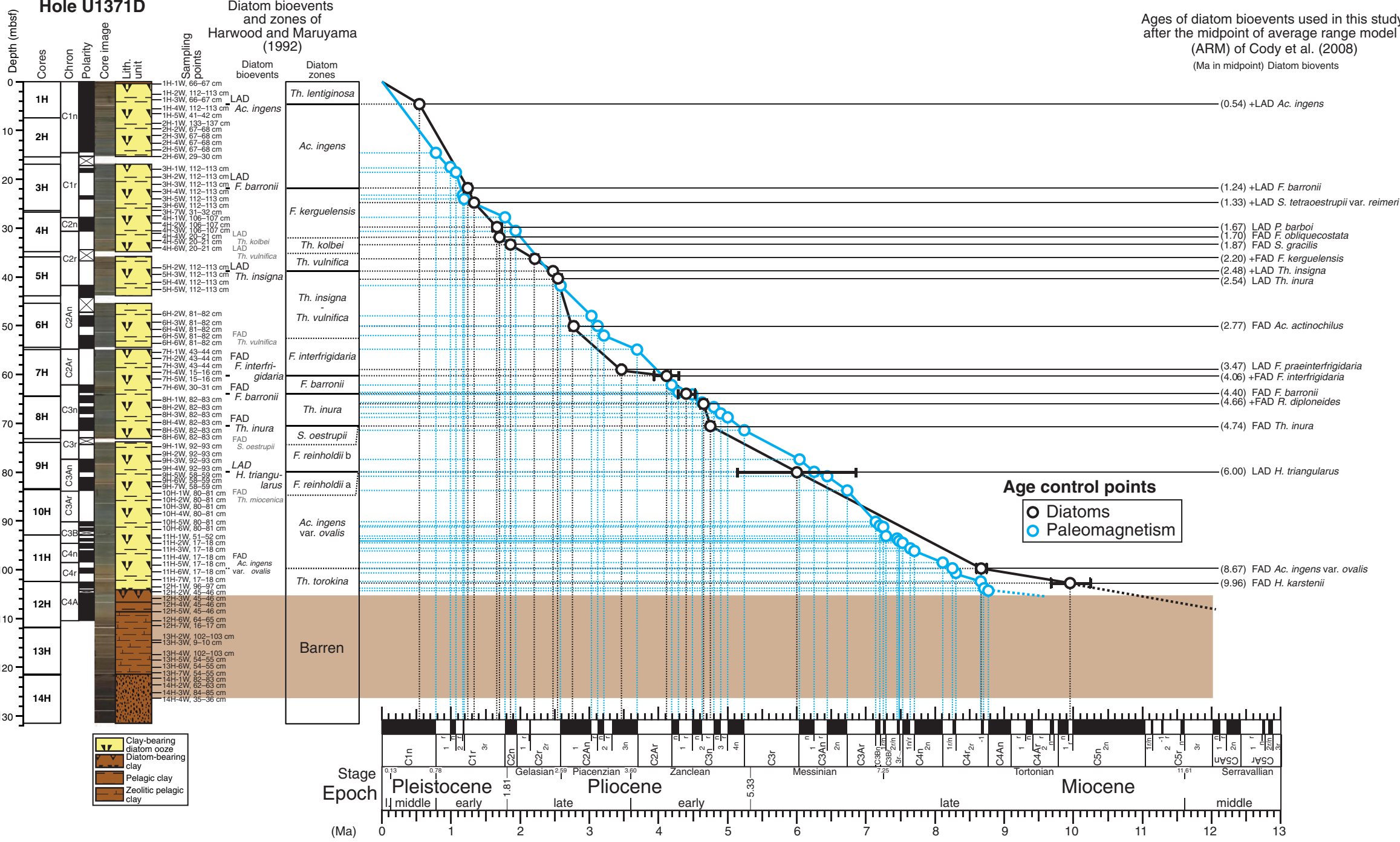


Table T1. Diatom occurrences, Hole U1371D. This table is available in an oversized format.

Table T2. Diatom datum events, Hole U1371D.

\begin{tabular}{|c|c|c|c|c|c|c|c|}
\hline \multirow[b]{2}{*}{ Datum event } & \multirow[b]{2}{*}{ Age $(\mathrm{Ma})^{\star}$} & \multicolumn{2}{|c|}{ Core, section, interval $(\mathrm{cm})$} & \multicolumn{4}{|c|}{ Depth CSF-A (m) } \\
\hline & & Top & Bottom & Error & Top & Median & Bottom \\
\hline & & 329-U1371D- & 329-U1371D- & & & & \\
\hline LAD Actinocyclus ingens & $0.50-0.57$ & $1 \mathrm{H}-3 \mathrm{~W}, 66-67$ & 1H-4W, 112-113 & $4.64 \pm 0.98$ & 3.66 & 4.64 & 5.62 \\
\hline LAD Fragilariopsis barronii & $1.19-1.29$ & $3 \mathrm{H}-3 \mathrm{~W}, 112-113$ & $3 \mathrm{H}-4 \mathrm{~W}, 112-113$ & $21.77 \pm 0.75$ & 21.02 & 21.77 & 22.52 \\
\hline LAD Shionodiscus tetraoestrupii var. reimeri & $1.31-1.34$ & $3 \mathrm{H}-5 \mathrm{~W}, 112-113$ & $3 \mathrm{H}-6 \mathrm{~W}, 112-113$ & $24.77 \pm 0.75$ & 24.02 & 24.77 & 25.52 \\
\hline LAD Proboscia barboi & $1.60-1.73$ & $4 \mathrm{H}-2 \mathrm{~W}, 106-107$ & $4 \mathrm{H}-3 \mathrm{~W}, 106-107$ & $29.71 \pm 0.75$ & 28.96 & 29.71 & 30.46 \\
\hline FAD Fragilariopsis obliquecostata & $1.66-1.73$ & $4 \mathrm{H}-4 \mathrm{~W}, 20-21$ & $4 \mathrm{H}-5 \mathrm{~W}, 20-21$ & $31.85 \pm 0.75$ & 31.10 & 31.85 & 32.60 \\
\hline FAD Thalassiosira gracilis & 1.87 & $4 \mathrm{H}-5 \mathrm{~W}, 20-21$ & $4 \mathrm{H}-6 \mathrm{~W}, 20-21$ & $33.35 \pm 0.75$ & 32.60 & 33.35 & 34.10 \\
\hline FAD Fragilariopsis kerguelensis & $2.18-2.21$ & $4 \mathrm{H}-6 \mathrm{~W}, 20-21$ & $5 \mathrm{H}-2 \mathrm{~W}, 112-113$ & $36.11 \pm 0.75$ & 34.10 & 36.11 & 38.12 \\
\hline LAD Thalassiosira insigna & $2.45-2.50$ & $5 \mathrm{H}-2 \mathrm{~W}, 112-113$ & $5 \mathrm{H}-3 \mathrm{~W}, 112-113$ & $38.87 \pm 0.75$ & 38.12 & 38.87 & 39.62 \\
\hline LAD Thalassiosira inura & $2.53-2.55$ & $5 \mathrm{H}-3 \mathrm{~W}, 112-113$ & $5 \mathrm{H}-4 \mathrm{~W}, 112-113$ & $40.37 \pm 0.75$ & 39.62 & 40.37 & 41.12 \\
\hline FAD Actinocyclus actinochilus & $2.72-2.81$ & $6 \mathrm{H}-3 \mathrm{~W}, 81-82$ & $6 \mathrm{H}-4 \mathrm{~W}, 81-82$ & $49.96 \pm 0.75$ & 49.21 & 49.96 & 50.71 \\
\hline LAD Fragilariopsis praeinterfrigidaria & $3.45-3.49$ & $7 \mathrm{H}-4 \mathrm{~W}, 15-16$ & 7H-5W, 15-16 & $60.30 \pm 0.75$ & 59.55 & 60.30 & 61.05 \\
\hline FAD Fragilariopsis interfrigidaria & $3.93-4.19$ & $7 \mathrm{H}-4 \mathrm{~W}, 15-16$ & 7H-5W, 15-16 & $60.30 \pm 0.75$ & 59.55 & 60.30 & 61.05 \\
\hline FAD Fragilariopsis barronii & $4.28-4.52$ & $7 \mathrm{H}-6 \mathrm{~W}, 30-31$ & $8 \mathrm{H}-1 \mathrm{~W}, 82-83$ & $63.96 \pm 1.26$ & 62.70 & 63.96 & 65.22 \\
\hline FAD Rouxia diploneides & $4.61-4.70$ & $8 \mathrm{H}-1 \mathrm{~W}, 82-83$ & $8 \mathrm{H}-2 \mathrm{~W}, 82-83$ & $65.97 \pm 0.75$ & 65.22 & 65.97 & 66.72 \\
\hline FAD Thalassiosira inura & $4.71-4.77$ & $8 \mathrm{H}-4 \mathrm{~W}, 82-83$ & $8 \mathrm{H}-5 \mathrm{~W}, 82-83$ & $70.47 \pm 0.75$ & 69.72 & 70.47 & 71.22 \\
\hline LAD Hemidiscus triangularus & $5.14-6.86$ & $9 \mathrm{H}-4 \mathrm{~W}, 92-93$ & $9 \mathrm{H}-5 \mathrm{~W}, 58-59$ & $79.90 \pm 0.58$ & 79.32 & 79.90 & 80.48 \\
\hline FAD Actinocyclus ingens var. ovalis & $8.60-8.74$ & $11 \mathrm{H}-5 \mathrm{~W}, 17-18$ & $11 \mathrm{H}-6 \mathrm{~W}, 17-18$ & $99.83 \pm 0.75$ & 99.08 & 99.83 & 100.58 \\
\hline FAD Hemidiscus karstenii & $9.68-10.24$ & $11 \mathrm{H}-7 \mathrm{~W}, 17-18$ & $12 \mathrm{H}-1 \mathrm{~W}, 96-97$ & $102.72 \pm 0.64$ & 102.08 & 102.72 & 103.36 \\
\hline
\end{tabular}

* = average range model ages from Cody et al. (2008). LAD = last appearance datum, FAD = first appearance datum. 
Plate P1. Selected biostratigraphically useful diatoms, Hole U1371D. Scale bars $=10 \mu \mathrm{m}$ (right: figs. 1-8, 11-28; left: figs. 9, 10). 1, 2. Actinocyclus ingens Rattray (Sample 329-U1371D-2H-6W, 29-30 cm). 3, 4. Shionodiscus tetraoestrupii var. reimeri (Mahood et Barron) Alverson et al. (Sample 3H-6W, 112-113 cm). 5, 6. Hemidiscus triangularus (Jousé) Harwood et Maruyama (Sample 9H-2W, 92-93 cm). 7, 8. Thalassiosira insigna (Jousé) Harwood et Maruyama (Sample 5H-3W, 112-113 cm). 9, 10. Proboscia barboi (Brun) Jordan et Priddle (Sample 4H-3W, 106-107 cm). 11, 12. Rouxia diploneides Schrader (Sample 2H-5W, 67-68 cm). 13, 14. Fragilariopsis interfrigidaria (McCollum) Gersonde et Bárcena (Sample 6H-2W, 81-82 cm). 15, 16. Fragilariopsis praeinterfrigidaria (McCollum) Gersonde et Bárcena (Sample 7H-4W, 15-16 cm). 17, 18. Fragilariopsis barronii (Gersonde) Gersonde et Bárcena (Sample 3H-4W, 112-113 cm). 19, 20. Fragilariopsis kerguelensis (O'Meara) Hustedt (Sample $3 \mathrm{H}-1 \mathrm{~W}, 112-113 \mathrm{~cm}) .21,22$. Shionodiscus gracilis (Karsten) Alverson et al. (Sample 4H-4W, 20-21 cm). 23, 24. Thalassiosira inura Gersonde (Sample 8H-4W, 82-83 cm). 25, 26. Hemidiscus karstenii Jousé in Jousé et al. (Sample 7H-2W, 43-44 cm). 27, 28. Actinocyclus ingens var. ovalis Gersonde (Sample 10H-2W, 80-81 cm).

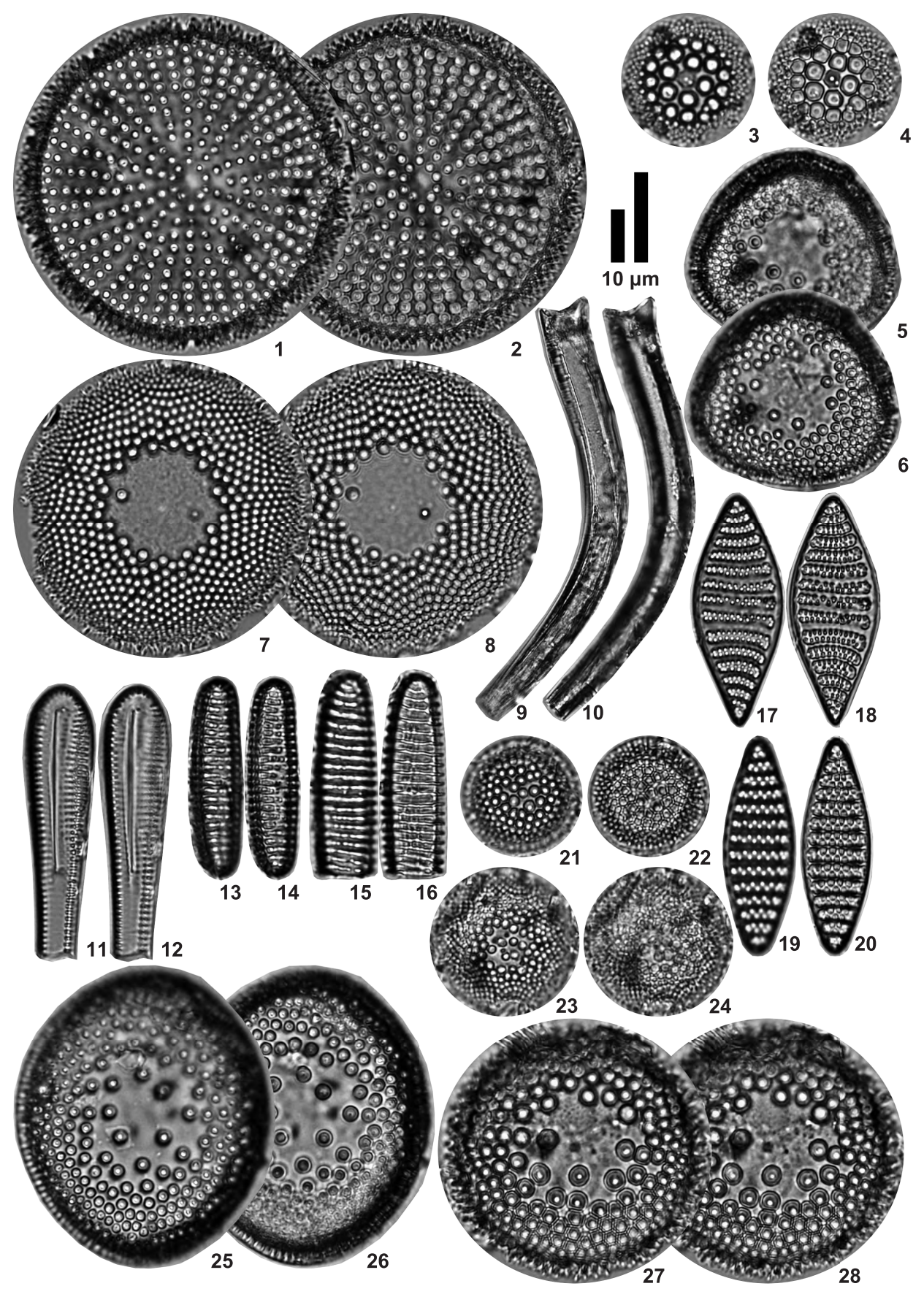


Plate P2. Light microscope images of diatoms, Hole U1371D. Scale bar $=10 \mu \mathrm{m} .1,2$. Actinocyclus curvatulus Janisch in Schmidt et al. (Sample 329-U1371D-9H-2W, 92-93 cm). 3, 4. Actinocyclus ellipticus Grunow in Van Heurck (Sample 9H-6W, 58-59 cm). 5, 6. Actinocyclus karstenii Van Heurck (Sample 7H-5W, 15-16 cm). 7, 8. Actinocyclus sp. A (Sample 2H-5W, 67-68 cm). 9, 10. Actinoptychus senarius (Ehrenberg) Ehrenberg (Sample $3 \mathrm{H}-6 \mathrm{~W}, 112-113 \mathrm{~cm}) .11,12$. Actinoptychus vulgaris Schumann (Sample 2H-4W, 67-68 cm). 13, 14. Asterolampra sp. (Sample 10H-2W, 80-81 cm).

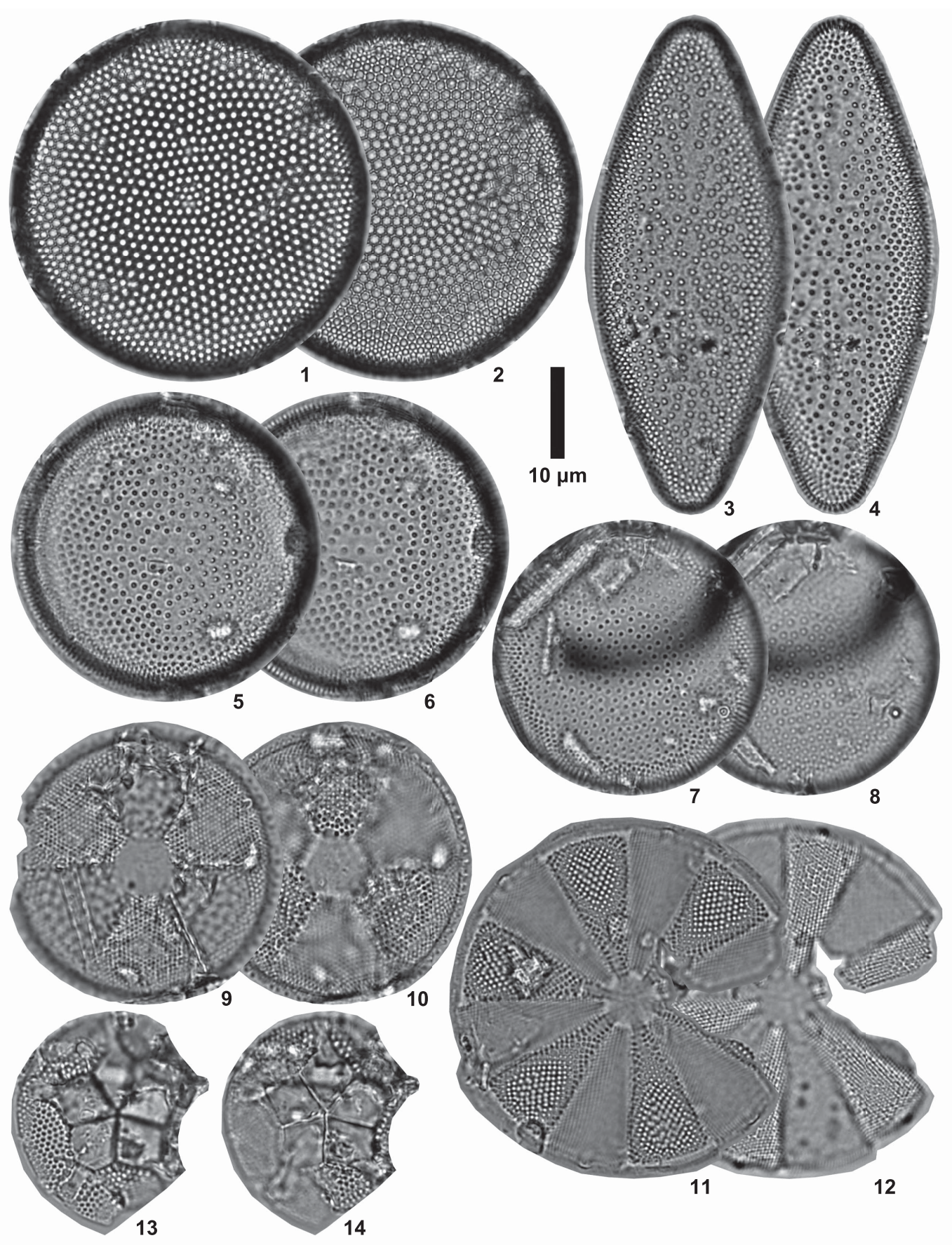


Plate P3. Light microscope images of diatoms, Hole U1371D. Scale bars $=10 \mu \mathrm{m}$ (right: figs. 1, 2, 5-8; left: figs. 3, 4). 1, 2. Asteromphalus kennettii Gersonde (Sample 329-U1371D-10H-3W, 80-81 cm). 3, 4. Asteromphalus oligocenicus Schrader et Fenner (Sample 10H-4W, 80-81 cm). 5, 6. Asteromphalus parvulus Karsten (Sample 3H-1W, 112-113 cm). 7, 8. Asteromphalus sp. (Sample 10H-5W, 80-81 cm).

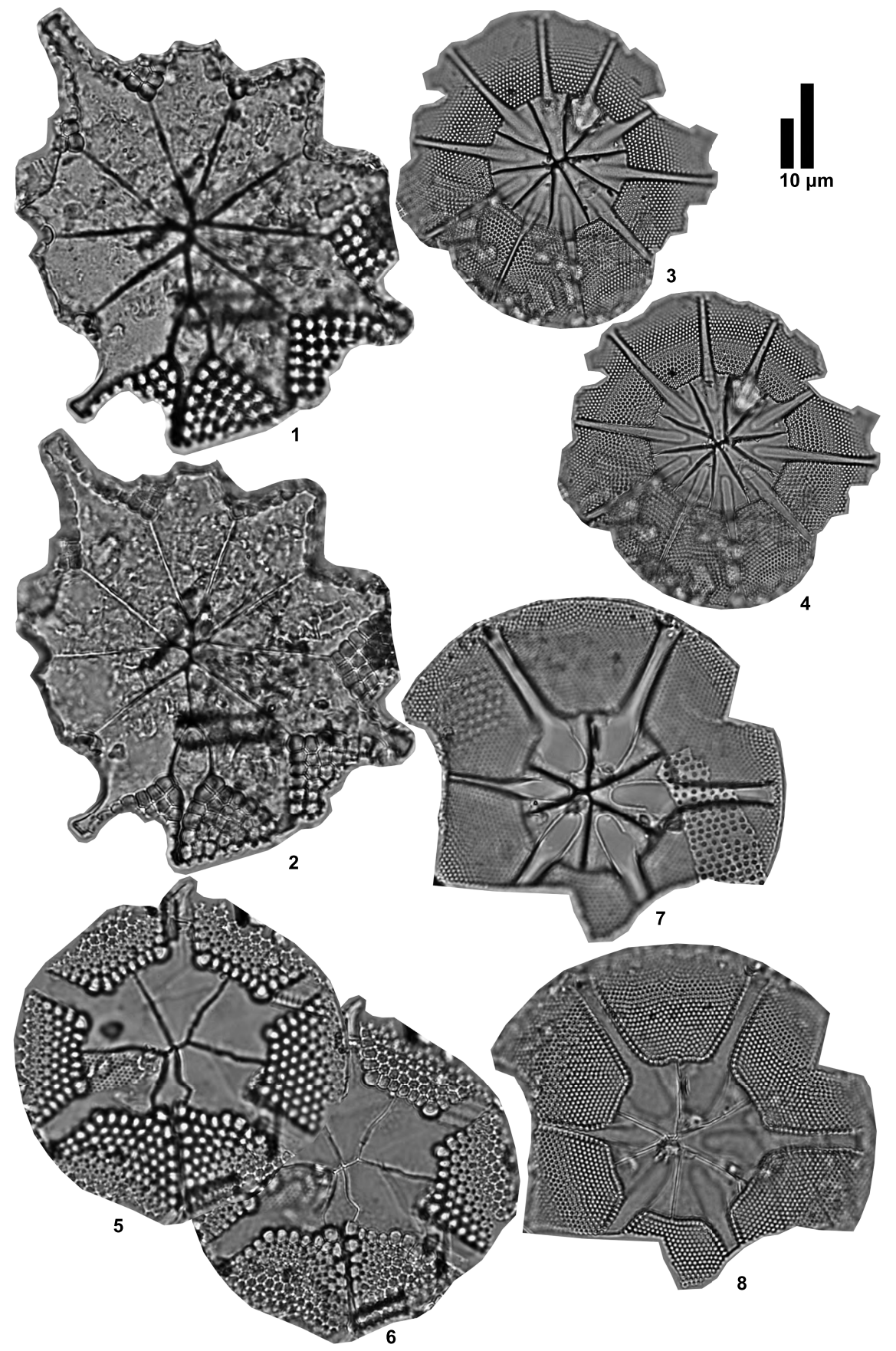


Plate P4. Light microscope images of diatoms, Hole U1371D. Scale bar $=10 \mu \mathrm{m} .1$, 2. Azpeitia endoi (Kanaya) Sims et Fryxell in Fryxell et al. (Sample 329-U1371D-10H-5W, 80-81 cm). 3, 4. Azpeitia tabularis (Grunow) Fryxell et Sims in Fryxell et al. (Sample 8H-4W, 82-83 cm). 5-7. Azpeitia vetustissima (Pantocsek) Sims in Fryxell et al. (Sample 7H-5W, 15-16 cm). 8-10. Bacteriastrum sp. (Sample 8H-4W, 82-83 cm). 11, 12. Biddulphia sp. (Sample 6H-5W, 81-82 cm). 13, 14. Bogorovia gombosii (Desikachary) Yanagisawa (Sample 3H-6W, 112-113 $\mathrm{cm}) .15,16$. Chaetoceros sp. (vegetative cells). 17, 18. Cocconeis californica (Grunow in Cleve et Möller) Grunow in Van Heurck (Sample 2H-3W, 67-68 cm). 19, 20. Cocconeis placentula Ehrenberg (Sample 6H-6W, 81-82 cm). 21-24. Cocconeis sp. B (Sample 1H-1W, 66-67 cm).

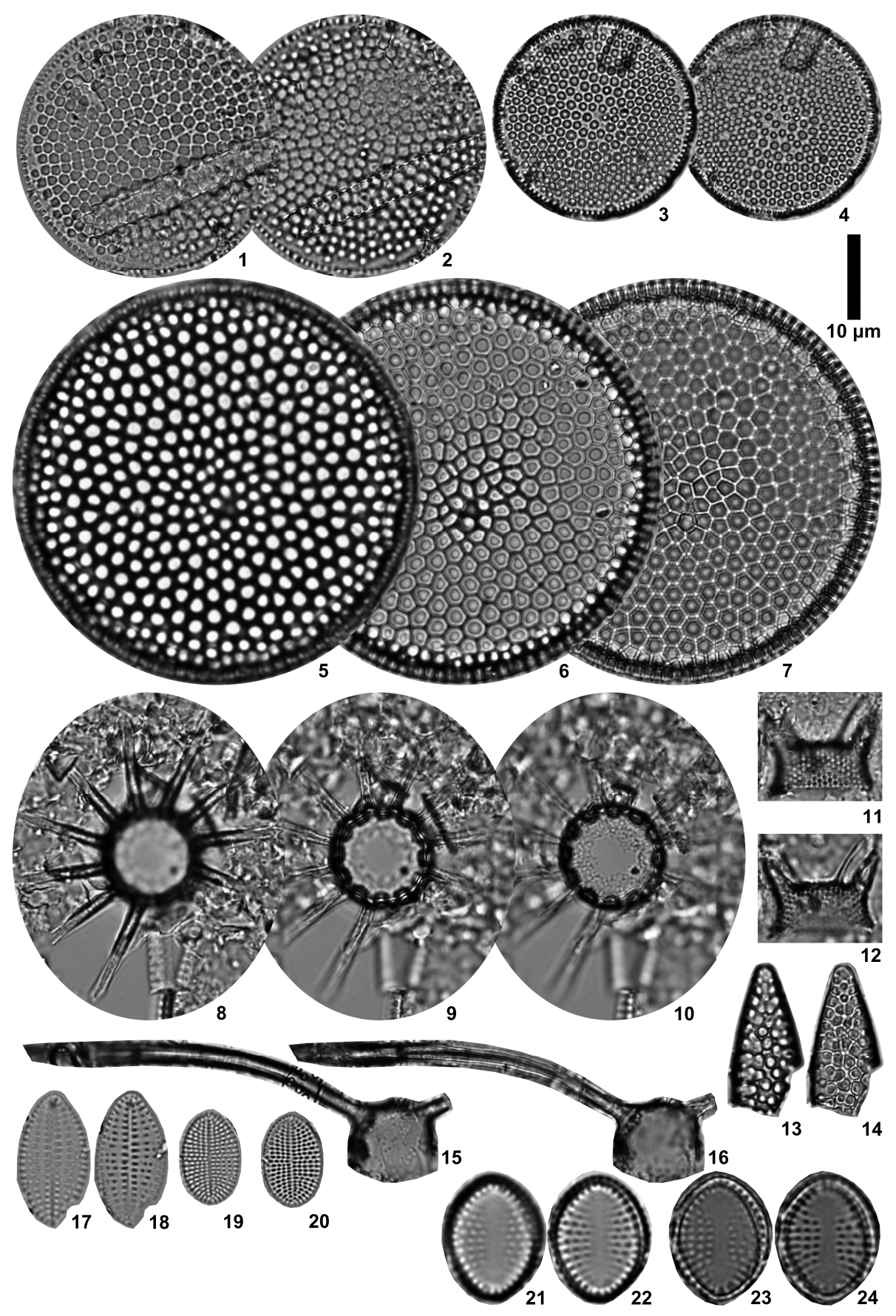


Plate P5. Light microscope images of diatoms, Hole U1371D. Scale bars $=10 \mu \mathrm{m}$ (right: figs. 1, 2, 5-8, 11-38; left: figs. 3, 4, 9, 10). 1, 2. Coscinodiscus marginatus Ehrenberg (Sample 329-U1371D-10H-3W, 80-81 cm). 3, 4. Coscinodiscus radiatus Ehrenberg (Sample 1H-1W, 66-67 cm). 5-8. Costopyxis trochlea (Hanna) Strelnikova in Gleser et al.; $(5,6)$ Sample 4H-4W, 20-21 cm; $(7,8)$ Sample 8H-2W, 82-83 cm. 9, 10. Crucidenticula kanayae Akiba et Yanagisawa (Sample 7H-2W, 43-44 cm). 11, 12. Crucidenticula nicobarica (Grunow) Akiba et Yanagisawa (Sample 6H-3W, 81-82 cm). 13-16. Cyclotella pantanelliana Castracane (Sample 3H-3W, 112-113 cm). 17-19. Cymatosira sp. (Sample 8H-4W, 82-83 cm). 20-22. Denticulopsis crassa Yanagisawa et Akiba (Sample 11H-6W, 17-18 cm). 23-26. Closed copula of Denticulopsis dimorpha (Schrader) Simonsen; $(23,24)$ Sample 6H3W, 81-82 cm; $(25,26)$ Sample 11H-6W, 17-18 cm. 27-30. Denticulopsis katayamae Maruyama; $(27,28)$ Sample 9H-6W, 58-59 cm; $(29,30)$ Sample 8H-5W, 82-83 cm. 31, 32. Denticulopsis lauta (Bailey) Simonsen (Sample 11H-3W, 17-18 cm). 33-38. Denticulopsis maccollumii Simonsen; $(33,34)$ Sample 4H-5W, 20-21 cm; $(35,36)$ Sample 6H-3W, 81-82 cm; $(37,38)$ Sample $8 H-5 W, 82-83 \mathrm{~cm}$.

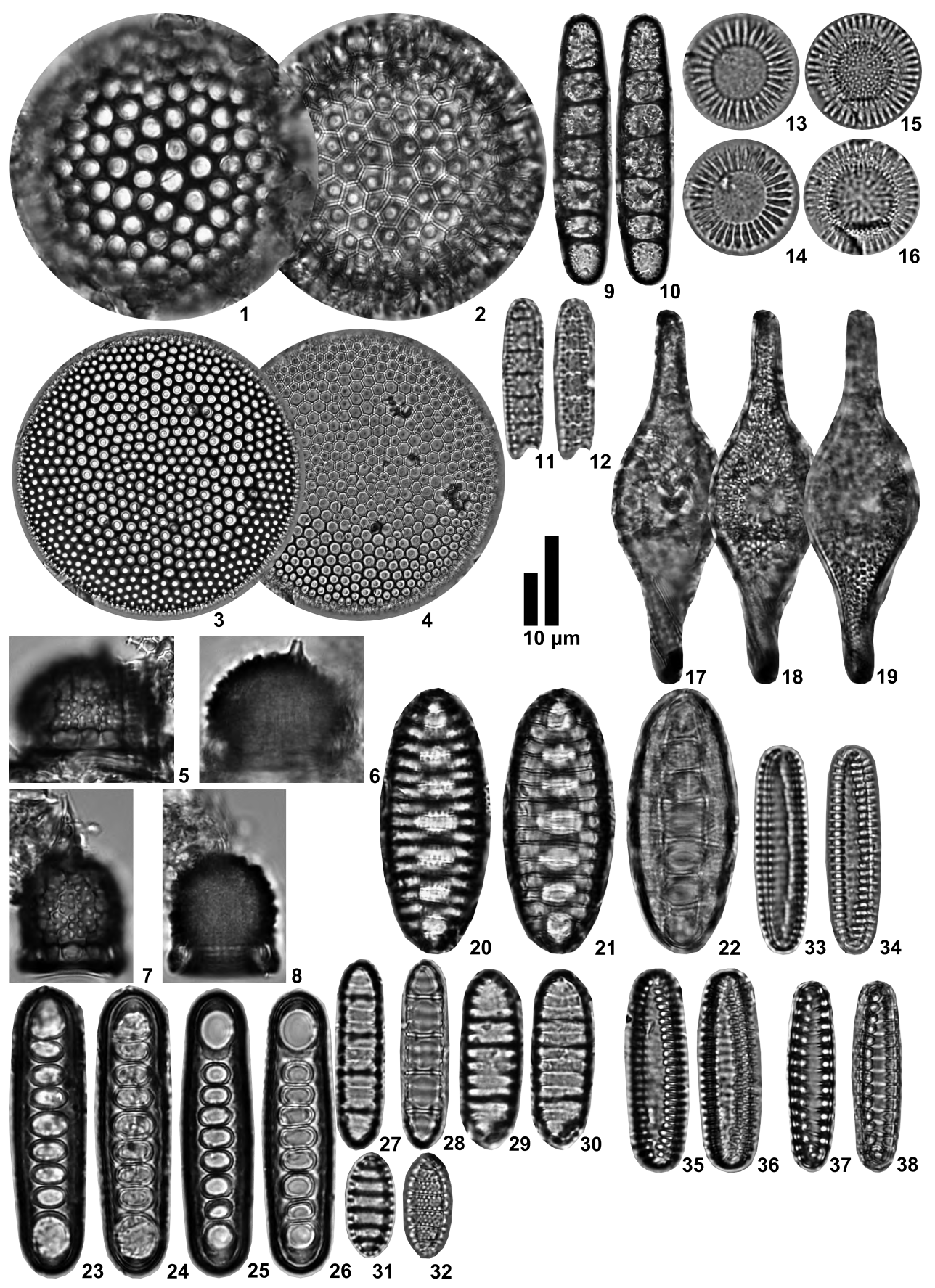


Plate P6. Light microscope images of diatoms, Hole U1371D. Scale bar $=10 \mu \mathrm{m}$. 1-6. Denticulopsis ovata (Schrader) Yanagisawa et Akiba; $(1,2)$ Sample 329-U1371D-3H-3W, 112-113 cm; (3-6) Sample 6H-5W, 81-82 cm. 7-12. Denticulopsis simonsenii Yanagisawa et Akiba; $(7,8)$ Sample 2H-6W, 29-30 cm; $(9,10)$ Sample 3H-3W, 112-113 cm; $(11,12)$ Sample 10H-3W, 80-81 cm. 13-16. Denticulopsis vulgaris (Okuno) Yanagisawa et Akiba; $(13,14)$ Sample 6H-3W, 81-82 cm; $(15,16)$ Sample 11H-6W, 17-18 cm. 17, 18. Diploneis bombus Ehrenberg (Sample 5H-3W, 112-113 cm). 19, 20. Discostella stelligera (Cleve et Grunow) Houk et Klee (Sample 3H-5W, 112-113 cm). 21, 22. Distephanosira architecturalis (Brun) Gleser in Gleser et al. (Sample 4H-4W, 20-21 cm). 23-26. Eucampia antarctica (Castracane) Mangin; $(23,24)$ Sample 1H-4W, 112-113 cm; $(25,26)$ Sample 4H-1W, 106-107 cm. 27-30. Fragilariopsis aurica (Gersonde) Gersonde et Bárcena; (27, 28) Sample 5H-4W, 112-113 cm; $(29,30)$ Sample 7H-3W, 43-44 cm. 31-38. Fragilariopsis curta (Van Heurck) Hustedt; $(31,32)$ Sample 3H-2W, 112-113 cm; (33-36) Sample 6H-3W, 81-82 cm; (37, 38) Sample 1H-5W, 41-42 cm. 39-42. Fragilariopsis cylindrica (Burckle) Censarek et Gersonde (Sample 4H-5W, 20-21 cm). 43, 44. Fragilariopsis doliolus (Wallich) Medlin et Sims (Sample 10H-6W, 80-81 cm). 45, 46. Fragilariopsis fossilis (Frenguelli) Medlin et Sims (Sample 1H-5W, 41-42 cm). 47, 48. Fragilariopsis maleinterpretaria (Schrader) Censarek et Gersonde (Sample 9H-6W, 58-59 cm). 49, 50. Fragilariopsis obliquecostata (Van Heurck) Heiden et Kolbe (Sample 4H-3W, 106-107 cm). 51, 52. Fragilariopsis oceanica (Cleve) Hasle (Sample 10H-5W, 80-81 cm). 53-56. Fragilariopsis reinholdii (Kanaya ex Schrader) Zielinski et Gersonde; $(53,54)$ Sample 5H-2W, 112-113 cm; $(55,56)$ Sample 7H-4W, 15-16 cm. 57, 58. Fragilariopsis ritscheri Hustedt (Sample 3H-1W, 112-113 cm). 59-64. Fragilariopsis separanda Hustedt; (59, 60) Sample 1H-4W, 112-113 cm; $(61,62)$ Sample 2H-5W, 67-68 cm; $(63,64)$ Sample 1H-1W, 66-67 cm. (Plate shown on next page.) 
Plate P6 (continued). (Caption shown on previous page.)

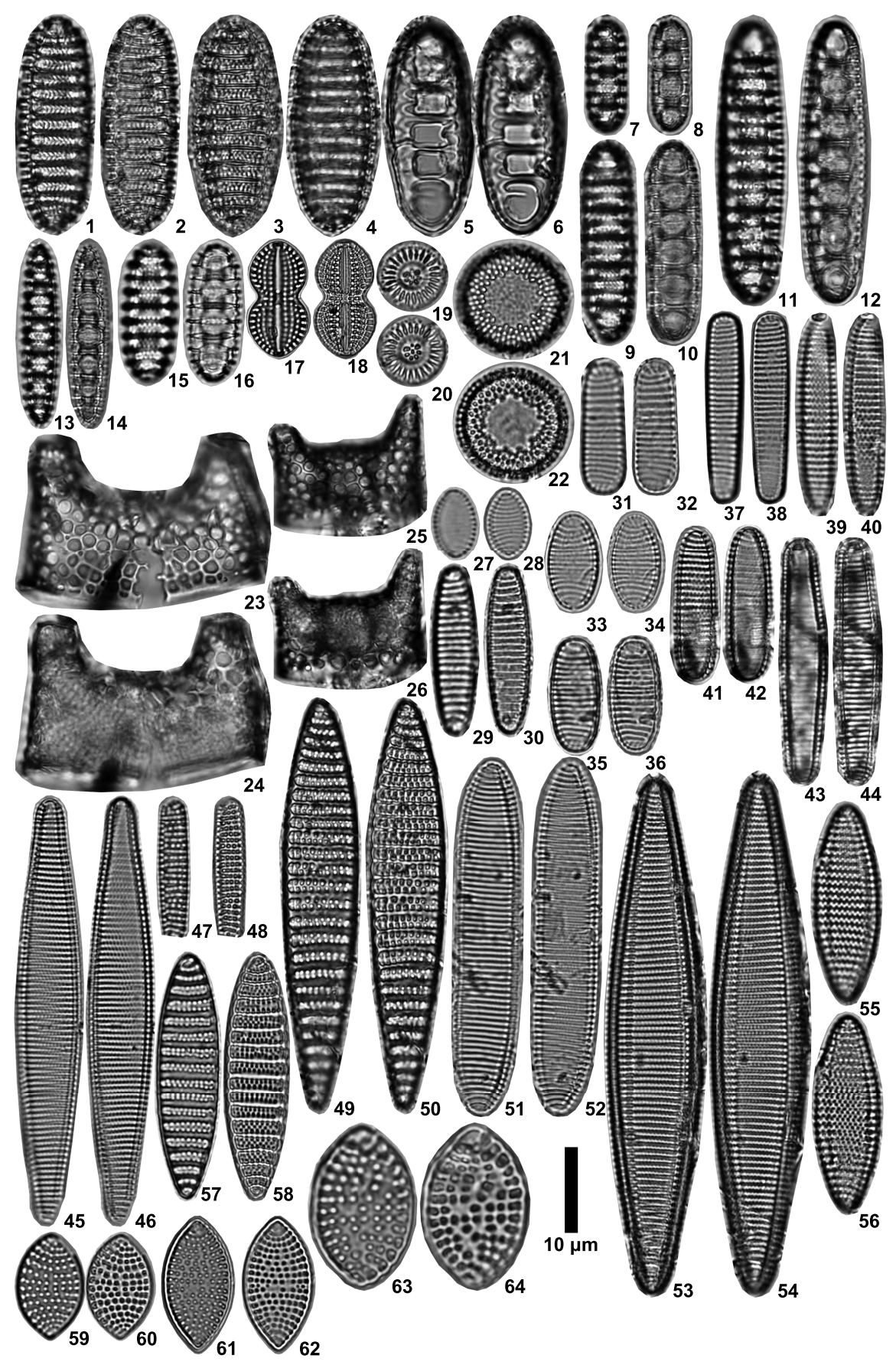


Plate P7. Light microscope images of diatoms, Hole U1371D. Scale bar $=10 \mu \mathrm{m} .1,2$. Fragilariopsis sublinearis (Van Heurck) Heiden et Kolbe (Sample 329-U1371D-4H-1W, 106-107 cm). 3, 4. Goniothecium rogersii Ehrenberg (Sample 10H-6W, 80-81 cm). 5-12. Hemiaulus spp.; (5-8) Sample 8H-5W, 82-83 cm; (9, 10) Sample 9H-2W, 92-93 cm; $(11,12)$ Sample 9H-4W, 92-93 cm. 13-16. Hemidiscus cuneiformis Wallich; $(13,14)$ Sample 1H-4W, 112-113 cm; $(15,16)$ Sample 8H-6W, 82-83 cm. 17, 18. Hemidiscus sp. 1 of Zielinski and Gersonde (2002) 19, 20. Hyalodiscus sp. (Sample 10H-6W, 80-81 cm). 21, 22. Koizumia adaroi (Azpeitia) Yanagisawa (Sample 11H-6W, 17-18 cm). 23, 24. Navicula sp. (Sample 1H-1W, 66-67 cm). 25-30. Odontella sp.?; (25, 26) Sample 10H-6W, 80-81 cm; (27-30) Sample 11H-3W, 17-18 cm. 31, 32. Opephora sp. (Sample 5H-2W, 112-113 cm).

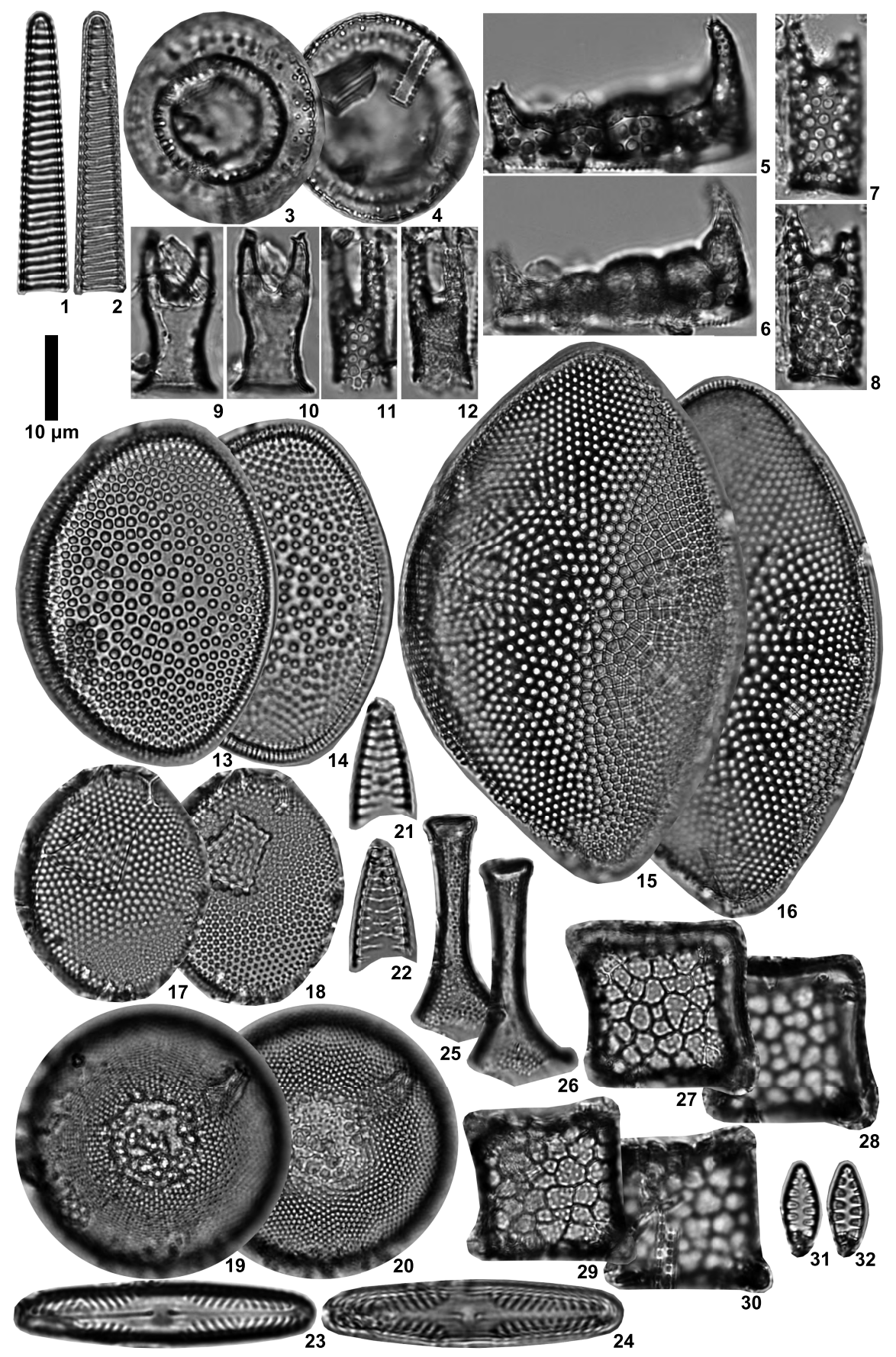


Plate P8. Light microscope images of diatoms, Hole U1371D. Scale bar $=10 \mu \mathrm{m}$. 1-4. Paralia sulcata (Ehrenberg) Cleve; $(1,2)$ Sample 329-U1371D-3H-2W, 112-113 cm; $(3,4)$ Sample 10H-3W, 80-81 cm. 5, 6. Pleurosigma sp. (Sample 4H-4W, 20-21 cm). 7, 8. Podosira sp. (Sample 3H-6W, 112-113 cm). 9-14. Proboscia alata (Brightwell) Sundström; $(9,10)$ Sample 2H-2W, 67-68 cm; $(11,12)$ Sample 4H-5W, $20-21 \mathrm{~cm}$; $(13,14)$ Sample 10H-4W, 80-81 cm. 15, 16. Pseudo-nitzschia sp. (Sample 5H-2W, 112-113 cm). 17, 18. Pseudopyxilla americana (Ehrenberg) Forti (Sample 9H-1W, 92-93 cm). 19, 20. Pterotheca aculeifera (Grunow in Van Heurck) Van Heurck (Sample 3H-7W, 32-33 cm). 21, 22. Rhizosolenia hebetata Bailey (Sample 3H-3W, 112-113 cm). 23-26. Rhizosolenia polydactyla Castracane; $(23,24)$ Sample 10H-4W, 80-81 cm; $(25,26)$ Sample 1H-1W, 66-67 cm. 27, 28. Rocella praenitida (Fenner) Fenner in Kim et Barron (Sample 6H-2W, 81-82 cm). 29, 30. Rouxia constricta Zielinski et Gersonde (Sample 2H-5W, 67-68 cm). 31, 32. Rouxia leventerae Bohaty et al. (Sample 6H-5W, 81-82 cm). 33, 34. Rouxia naviculoides Schrader (Sample 2H-6W, 29-30 cm).

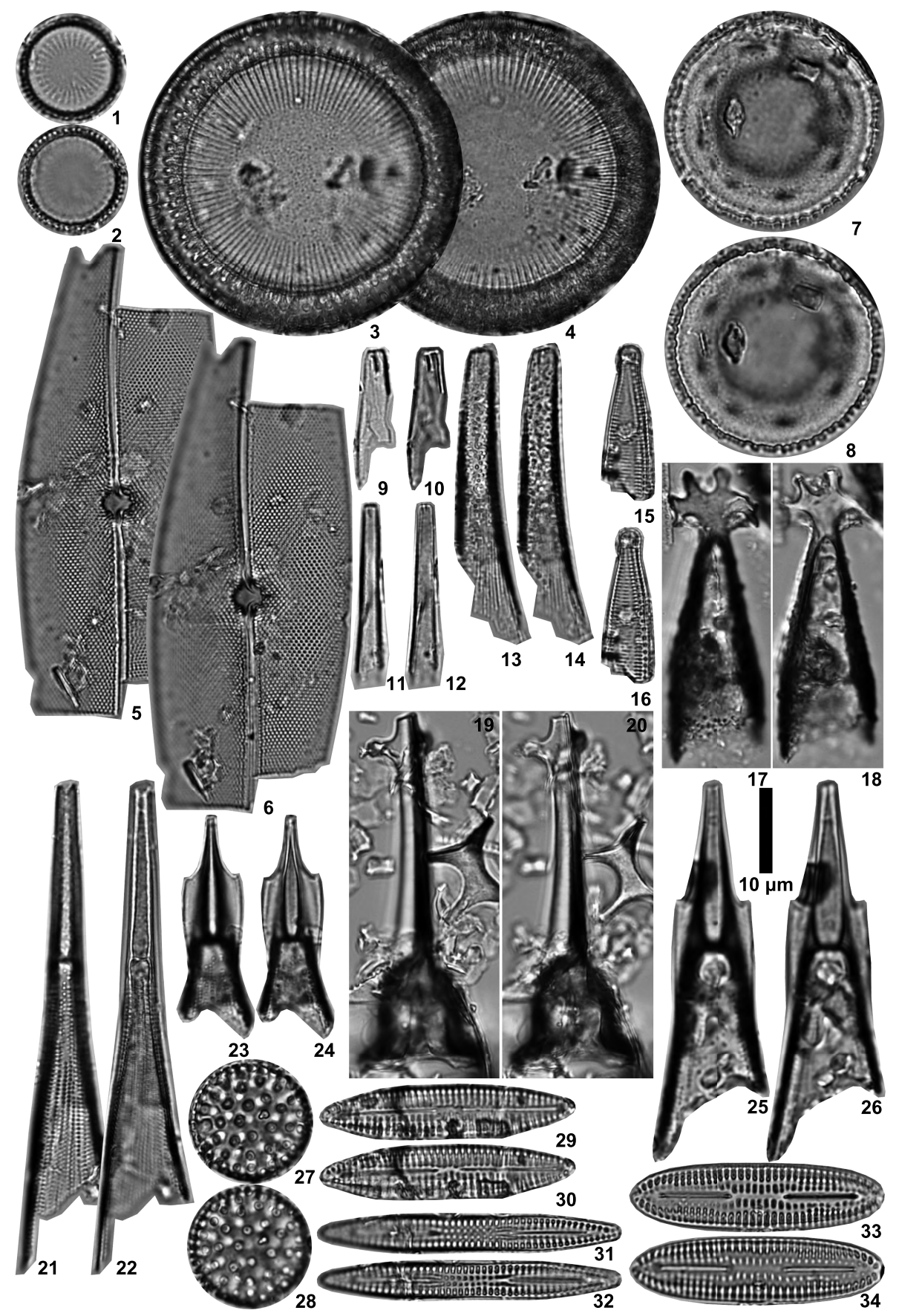


Plate P9. Light microscope images of diatoms, Hole U1371D. Scale bar $=10 \mu \mathrm{m}$. 1-6. Shionodiscus oestrupii (Ostenfeld) Alverson et al.; $(1,2)$ Sample 329-U1371D-1H-2W, 112-113 cm; $(3,4)$ Sample 2H-5W, 67-68 cm; $(5,6)$ Sample 4H-4W, 20-21 cm. 7, 8. Shionodiscus tetraoestrupii (Bodén) Alverson et al. (Sample 3H-6W, 112-113 cm). 9-18. Stephanopyxis spp.; $(9,10)$ Sample $1 \mathrm{H}-4 \mathrm{~W}, 112-113 \mathrm{~cm} ;(11,12)$ Sample 3H-6W, 112-113 cm; $(13,14)$ Sample 3H-7W, 32-33 cm; $(15,16)$ Sample 6H-4W, 81-82 cm; $(17,18)$ Sample 9H-2W, 92-93 cm. 19-22. Synedropsis recta Hasle et al.; $(19,20)$ Sample 10H-3W, 80-81 cm; $(21,22)$ Sample 2H-4W, 67-68 cm. 23, 24. Tetracyclus sp. (Sample 12H-2W, 45-46 cm). 25-40. Thalassionema nitzschioides (Grunow) Mereschkowsky; $(25,26)$ Sample 3H-5W, 112-113 cm; $(27,28)$ Sample 4H-6W, 20-21 cm; $(29,30)$ Sample 4H-2W, $106-107 \mathrm{~cm} ;(31,32)$ Sample 8H-1W, 82-83 cm; (33, 34) Sample 10H-6W, 80-81 cm; (35-38) Sample 9H-5W, 58-59 cm; $(39,40)$ Sample 3H-4W, 112-113 cm. 41-44. Thalassionema spp.; (41, 42) Sample 6H-6W, 81-82 cm; $(43,44)$ Sample $10 \mathrm{H}-4 \mathrm{~W}, 80-81 \mathrm{~cm}$.

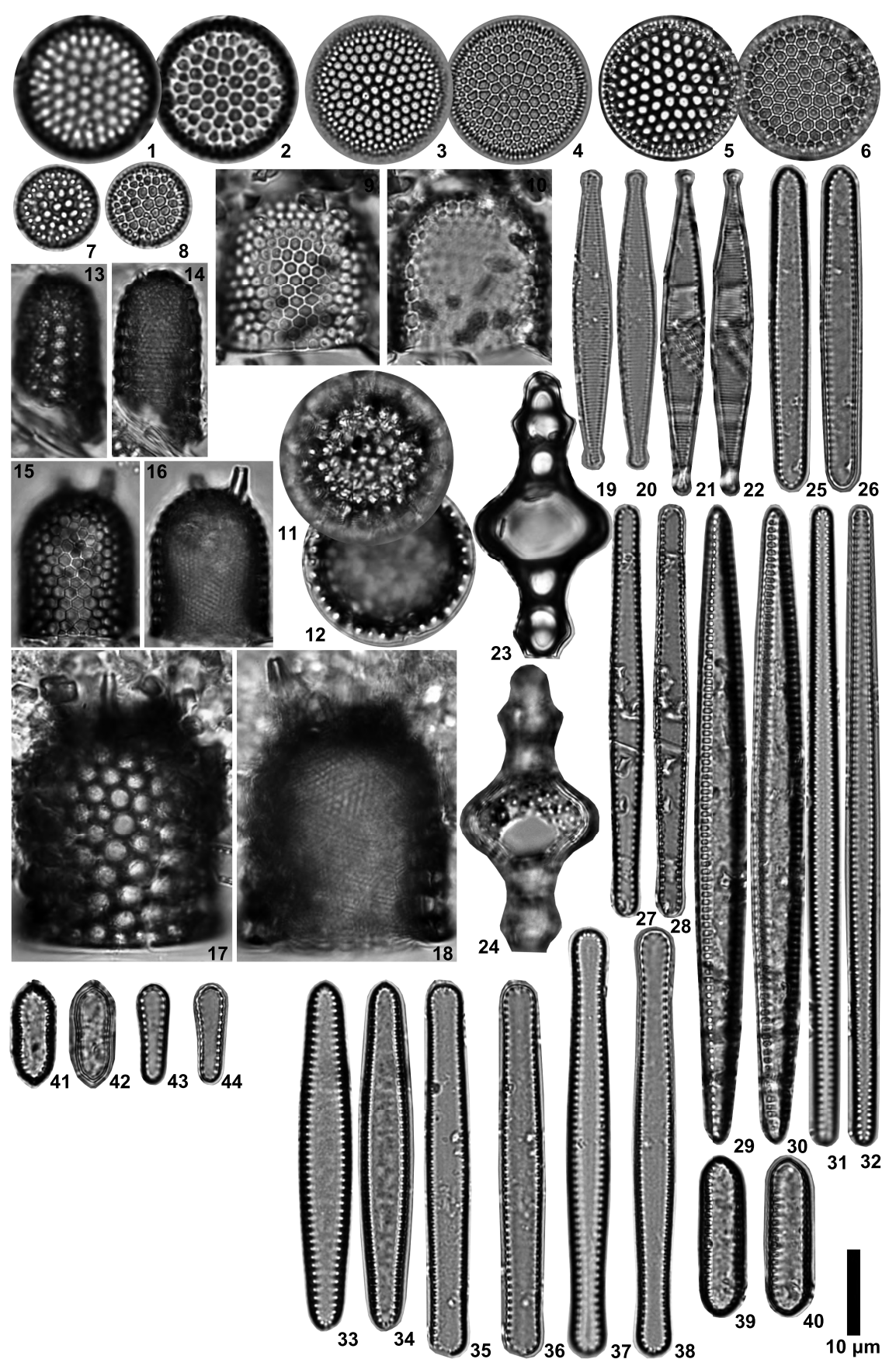


Plate P10. Light microscope images of diatoms, Hole U1371D. Scale bar $=10 \mu \mathrm{m}$. 1-10. Thalassionema sp. A; $(1,2)$ Sample 329-U1371D-8H-6W, 82-83 cm; (3, 4) Sample 9H-1W, 92-93 cm; $(5,6)$ Sample 8H-4W, 82-83 cm; $(7,8)$ Sample 6H-6W, 81-82 cm; $(9,10)$ Sample 7H-2W, 43-44 cm. 11, 12. Thalassiosira complicata Gersonde (Sample 7H-2W, 43-44 cm). 13-16. Thalassiosira eccentrica (Ehrenberg) Cleve; $(13,14)$ Sample 3H-6W, 112-113 cm; $(15,16)$ Sample 4H-5W, 20-21 cm. 17-20. Thalassiosira fasciculata Harwood et Maruyama; $(17,18)$ Sample $1 \mathrm{H}-4 \mathrm{~W}, 112-113 \mathrm{~cm}$; $(19,20)$ Sample 10H-6W, 80-81 cm. 21, 22. Thalassiosira kolbei (Jousé) Gersonde (Sample $4 \mathrm{H}-6 \mathrm{~W}, 20-21 \mathrm{~cm})$.

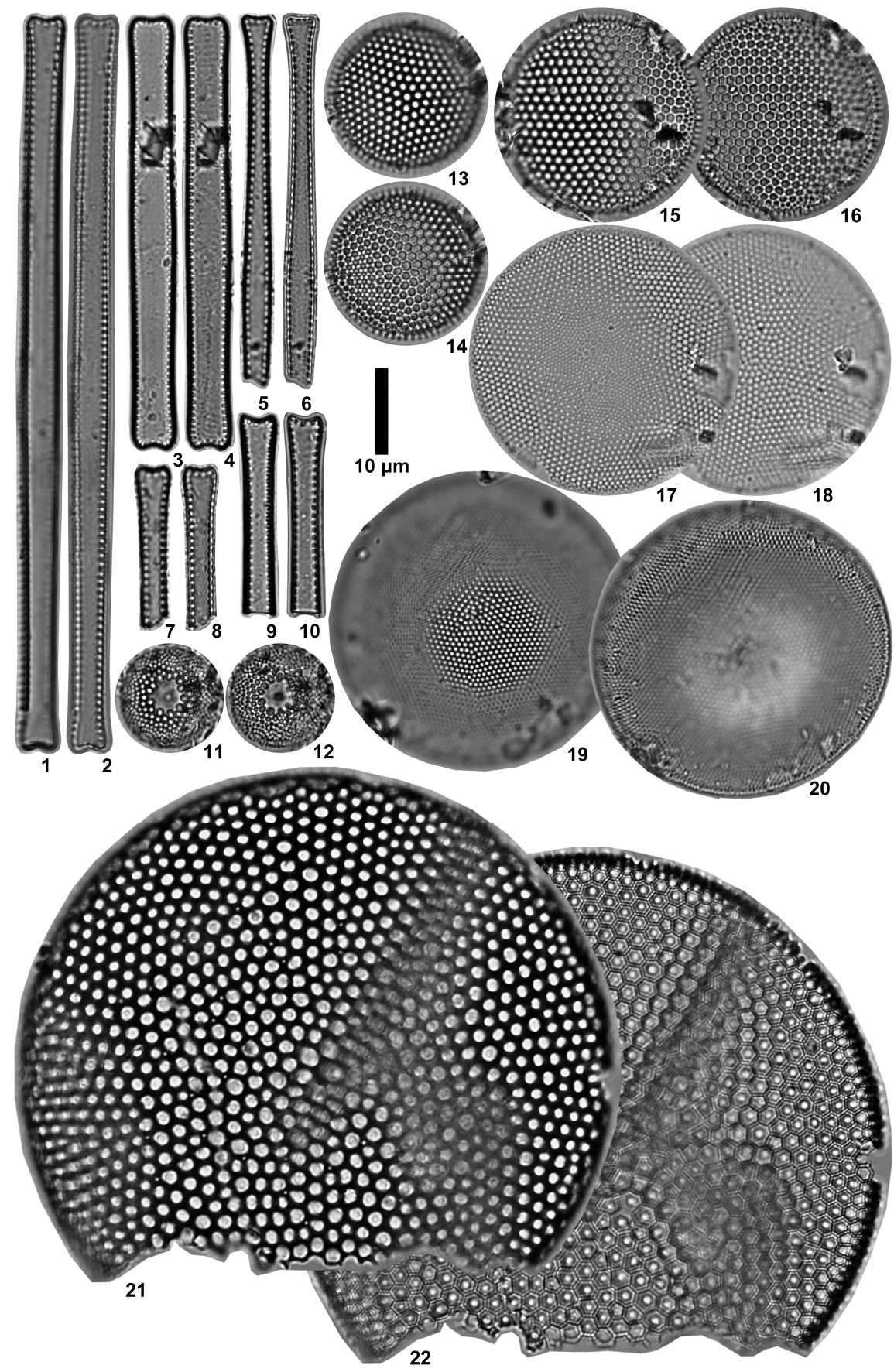


Plate P11. Light microscope images of diatoms, Hole U1371D. Scale bar $=10 \mu \mathrm{m} .1,2$. Thalassiosira lentiginosa (Janisch in Schmidt) Fryxell (Sample 329-U1371D-2H-3W, 67-68 cm). 3, 4. Thalassiosira cf. nativa SheshukovaPoretzkaya (Sample 4H-6W, 20-21 cm). 5, 6. Thalassiosira oliverana (O'Meara) Sournia in Sournia et al. (Sample $4 \mathrm{H}-6 \mathrm{~W}, 20-21 \mathrm{~cm}) .7$, 8. Thalassiosira oliverana var. sparsa Harwood et Maruyama (Sample 10H-6W, 80-81 cm). 9, 10. Thalassiosira striata Harwood et Maruyama (Sample 6H-2W, 81-82 cm). 11, 12. Thalassiosira cf. symmetrica Fryxell et Hasle (Sample 3H-4W, 112-113 cm). 13, 14. Thalassiosira tumida (Janisch) Hasle in Hasle et al. (Sample 5H-3W, 112-113 cm). 15, 16. Thalassiosira vulnifica (Gombos) Fenner (Sample 4H-3W, 106-107 $\mathrm{cm})$. 17, 18. Thalassiosira yabei (Kanaya) Akiba et Yanagisawa (Sample 11H-6W, 17-18 cm). 19-22. Thalassiothrix longissima Cleve et Grunow; $(19,20)$ Sample 2H-1W, 133-137 cm; $(21,22)$ Sample 4H-1W, 106-107 cm. 23-39. Triceratium spp.; (23-26) Sample 4H-3W, 106-107 cm; $(27,28)$ Sample 6H-5W, 81-82 cm; $(29-32)$ Sample 6H-6W, 81-82 cm; (33-35) Sample 7H-1W, 43-44 cm; $(36,37)$ Sample 9H-2W, 92-93 cm; $(38,39)$ Sample 8H-6W, 82-83 cm.

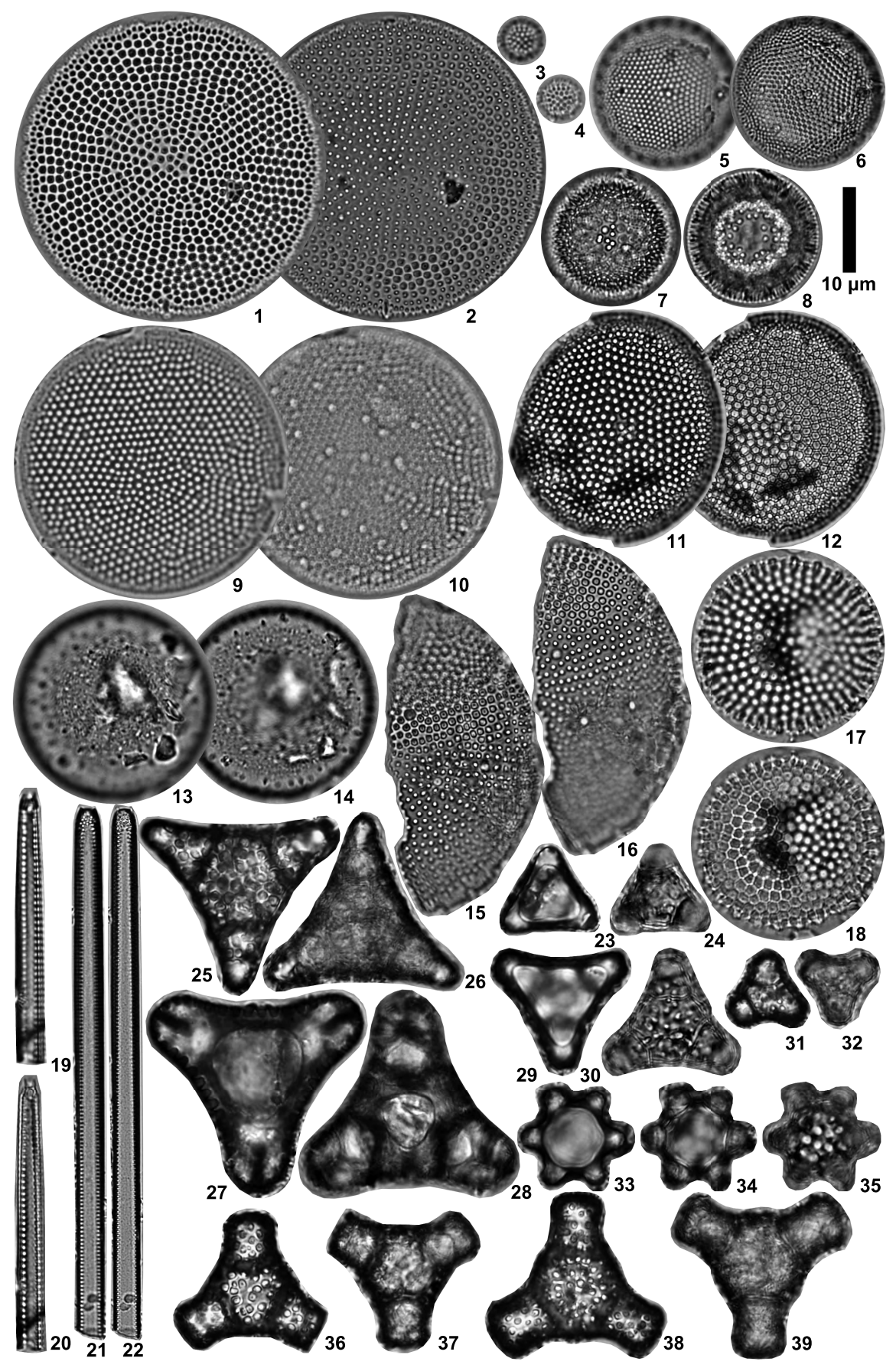


Plate P12. Light microscope images of resting spores of Chaetoceros, Hole U1371D. Scale bars $=10 \mu \mathrm{m}$. (right: figs. 1, 2, 4-40; left: figs. 3, 4). 1, 2. Coronodiscus collarius Suto (Sample 329-U1371D-11H-1W, 51-52 cm). 3, 4. Dicladia capreola Ehrenberg (Sample 3H-6W, 112-113 cm). 5, 6. Dispinodiscus pilusus var. pilusus Suto (Sample 3H-7W, 32-33 cm). 7, 8. Dispinodiscus sp. A (Sample 1H-1W, 66-67 cm). 9, 10. Gemellodiscus bifurcus Suto (Sample 5H-2W, 112-113 cm). 11, 12. Gemellodiscus cingulus var. cingulus Suto (Sample 4H-1W, 106-107 $\mathrm{cm}) .13,14$. Gemellodiscus geminus Suto (Sample 7H-5W, 15-16 cm). 15-18. Liradiscus castaneus var. castaneus Suto; $(15,16)$ Sample 4H-5W, 20-21 cm; $(17,18)$ Sample 4H-6W, 20-21 cm. 19-26. Liradiscus castaneus? (Sample 3H-7W, 32-33 cm). 27, 28. Liradiscus japonicus Suto (Sample 8H-3W, 82-83 cm). 29, 30. Liradiscus petasus Suto (Sample 8H-5W, 82-83 cm). 31-34. Liradiscus plicatulus Hajós; (31, 32) Sample 4H-5W, 20-21 cm; $(33,34)$ Sample 4H-6W, 20-21 cm. 35, 36. Quadrocistella paliesa Suto (Sample 8H-4W, 82-83 cm). 37-40. Quadrocistella sp. A; $(37,38)$ Sample 8H-3W, 82-83 cm; $(39,40)$ Sample $11 \mathrm{H}-7 \mathrm{~W}, 17-18 \mathrm{~cm}$.

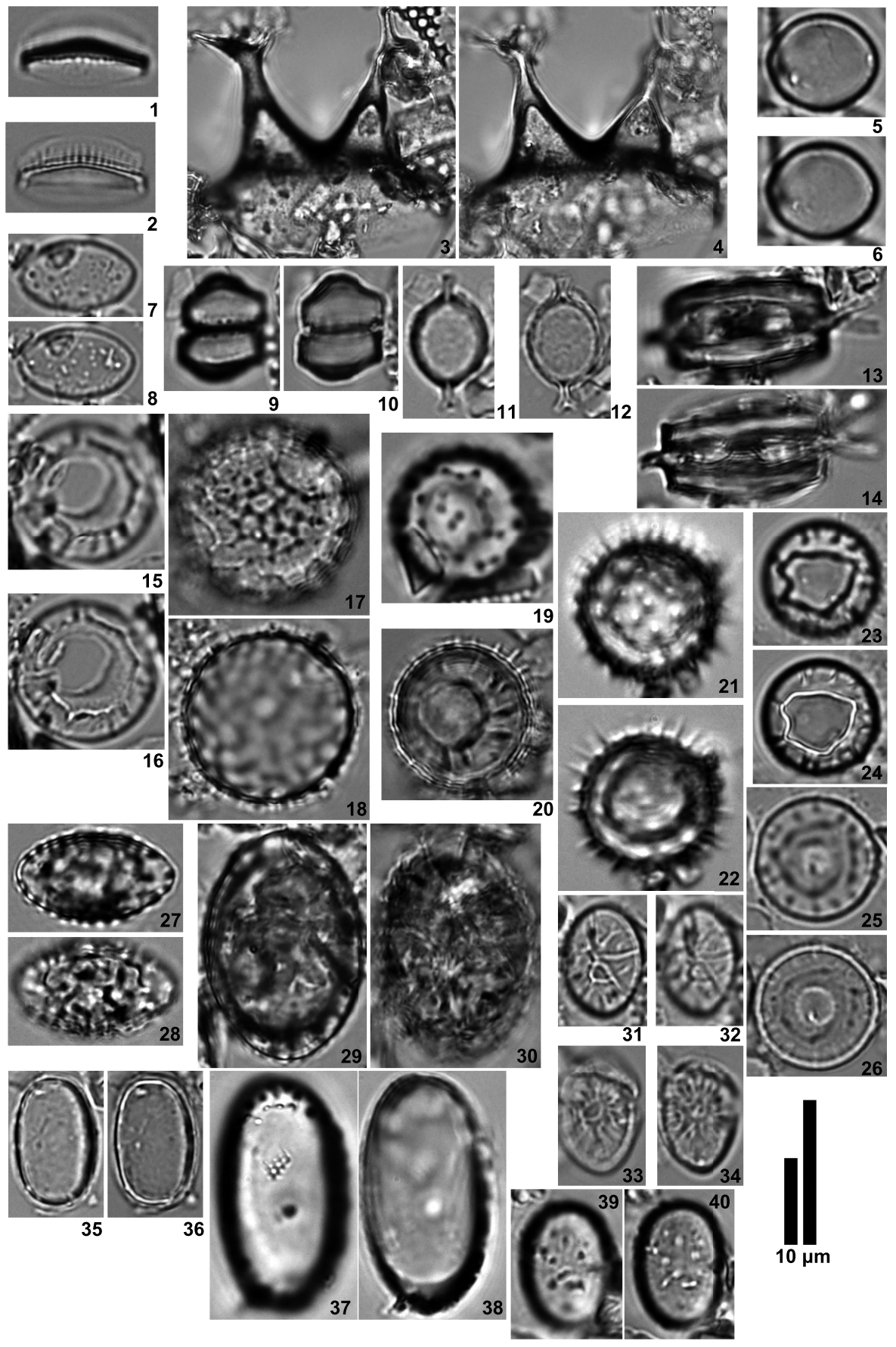


Plate P13. Light microscope images of resting spores of Chaetoceros, Hole U1371D. Scale bars $=10 \mu \mathrm{m}$. (right: figs. 3-16, 19, 20; left: figs. 1, 2, 17, 18, 21, 22). 1, 2. Syndendrium altantemna Suto (Sample 329-U1371D-6H3W, 81-82 cm). 3, 4. Syndendrium diadema Ehrenberg (Sample 1H-1W, 66-67 cm). 5-10. Truncatulus tortonicus (Hajós) Suto; $(5,6)$ Sample 5H-2W, 112-113 cm; (7, 8) Sample 4H-1W, 106-107 cm; $(9$, 10) Sample 8H-3W, 82-83 cm. 11, 12. Vallodiscus chinchae (Mereschkowski) Suto (Sample 8H-4W, 82-83 cm). 13-16. Vallodiscus complexus Suto; $(13,14)$ Sample 3H-2W, 112-113 cm; $(15,16)$ Sample 11H-4W, 17-18 cm. 17, 18. Xanthioisthmus biscoctiformis (Forti) Suto (Sample 10H-3W, 80-81 cm). 19, 20. Xanthioisthmus maculata (Hanna) Suto (Sample 8H-3W, 82-83 cm). 21, 22. Xanthioisthmus sp. A (Sample 3H-6W, 112-113 cm).

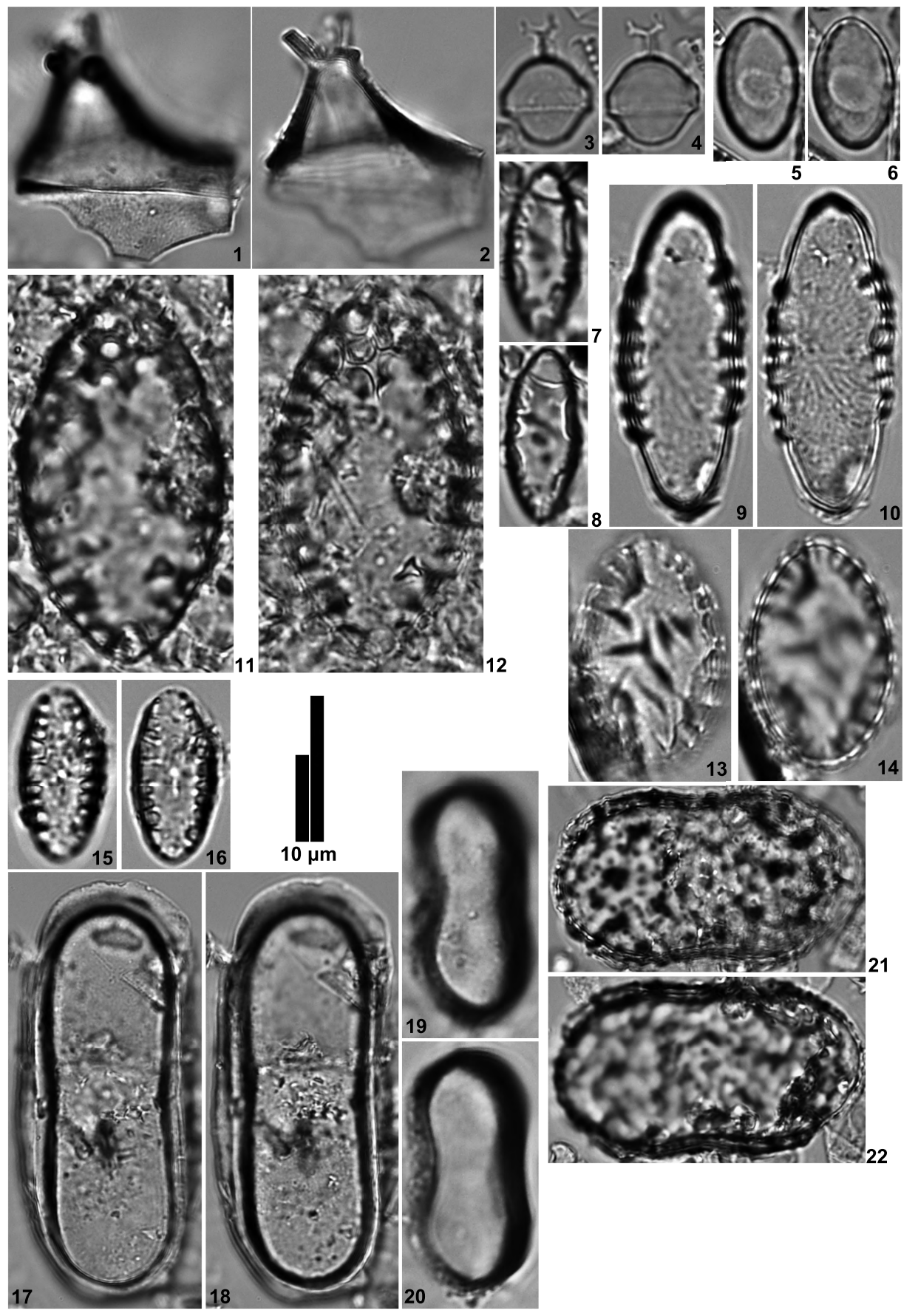


Plate P14. Light microscope images of resting spores of Chaetoceros, Hole U1371D. Scale bars = $10 \mu \mathrm{m}$. (right: figs. 10-13; left: figs. 1-9). 1-7. Xanthiopyxis acrolopha Forti; (1-3) Sample 329-U1371D-8H-4W, 82-83 cm; (4, 5) Sample 9H-4W, 92-93 cm; $(6,7)$ Sample 10H-2W, 80-81 cm. 8, 9. Xanthiopyxis oblonga Ehrenberg (Sample 7H-4W, 15-16 cm). 10, 11. Xanthiopyxis type A (knobbly type) (Sample 4H-4W, 20-21 cm). 12, 13. Xanthiopyxis type B (short spiny type) (Sample $8 \mathrm{H}-6 \mathrm{~W}, 82-83 \mathrm{~cm}$ ).
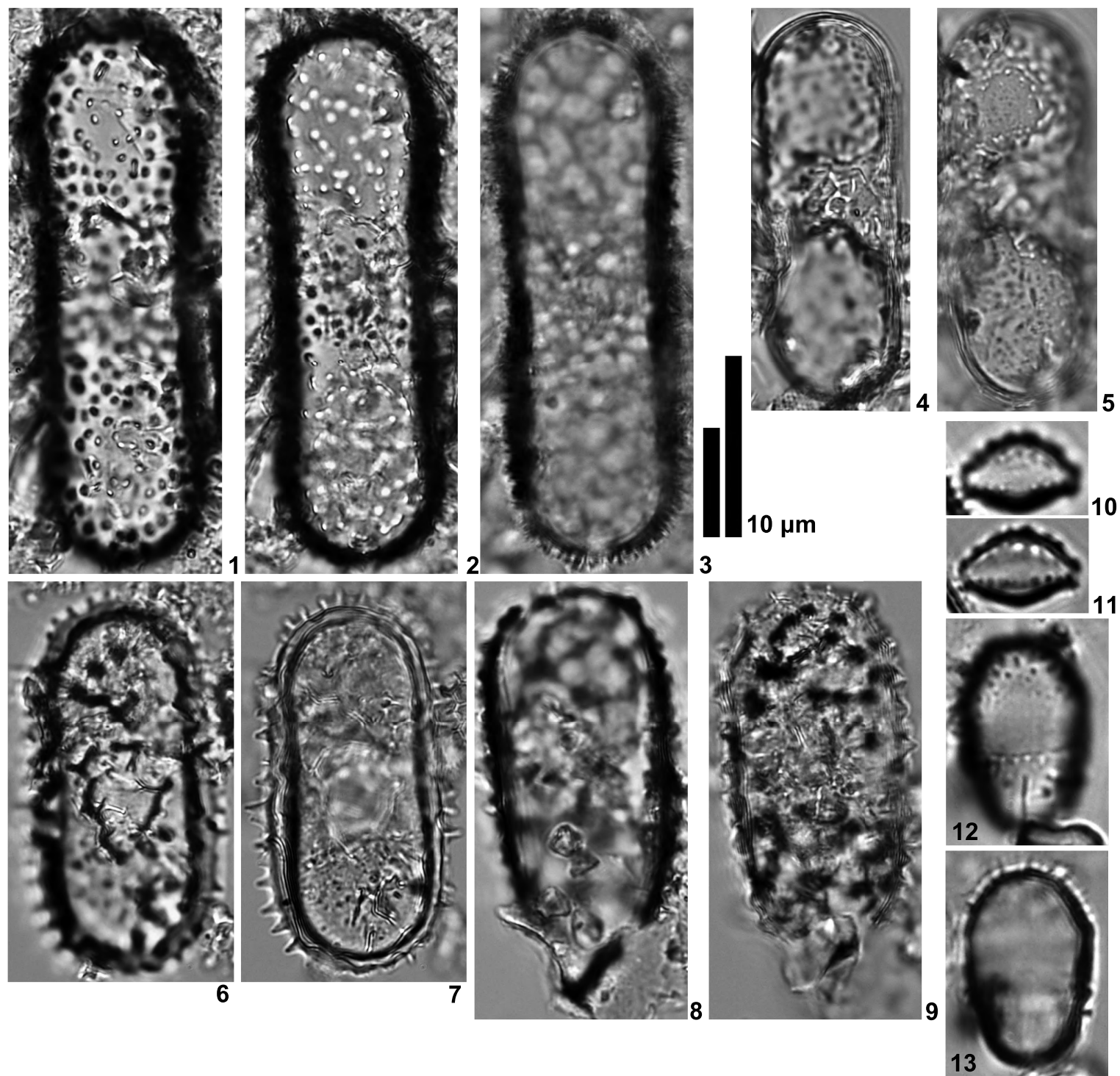


\section{Appendix}

\section{Taxonomic notes and floral references}

Taxonomic references for all species and varieties of diatoms (Bacillariophyta) identified from the Expedition 329 Hole U1371D sediments are listed below and shown in Plates P1-P14. The authority of each species is given as well as several good references that describe and illustrate the particular taxon collected around the Antarctic Ocean.

Actinocyclus actinochilus (Ehrenberg) Simonsen (1982), pp. 101-116, pls. 1-4; Harwood and Maruyama (1992), p. 699, pl. 12, figs. 9-11; Tanimura (1992), pp. 405, 407, figs. 3-2, 5-3; Mahood and Barron (1996b), p. 288, pl. 7, fig. 22; Bohaty et al. (1998), pl. 3, figs. 6, 8; Iwai and Winter (2002), p. 3, pl. P21, fig. 8; pl. P26, fig. 2; pl. P33, fig. 1; Suto et al. (2013), p. 32, pl. P1, figs. 1, 2 (no illustrations).

Basionym: Coscinodiscus actinochilus Ehrenberg (1844a), p. 200; Ehrenberg (1854), pl. 35A, figs. XXI-5.

Synonym: Charcotia actinochilus (Ehrenberg) Hustedt (1958), pp. 122-126, pl. 7, figs. 57-80; Fenner et al. (1976), p. 771, pl. 5, fig. 5; Gombos (1977), p. 592, pl. 1, fig. 8; Akiba (1982a), p. 42, pl. 3, figs. 7-10.

Actinocyclus curvatulus Janisch in Schmidt et al. (18741959), pl. 57, fig. 31; Fenner et al. (1976), p. 763, pl. 6, figs. 1, 2; Akiba (1982a), pp. 41, 42, pl. 5, figs. 5a, 5b; Harwood and Maruyama (1992), p. 699, pl. 12, fig. 12; Zielinski and Gersonde (2002), p. 253, pl. 3, fig. 1; Suto et al. (2013), p. 32, pl. P1, figs. 3-14 (Pl. P2, figs. 1, 2).

Actinocyclus ellipticus Grunow in Van Heurck (1880-1885), pl. 124, fig. 10; Schrader (1973), p. 701, pl. 8, figs. 7-9, 11-14, 16, 17; Akiba (1986), p. 441, pl. 16, fig. 5; Ciesielski (1986), p. 875, pl. 5, fig. 8 (Pl. P2, figs. 3, 4).

Actinocyclus ingens $\mathrm{f}$. ingens (Rattray) Whiting et Schrader (1985a), p. 74, pl. 1, figs. 1, 2; pl. 2, figs. 4-10; pl. 3, fig. 13 (Pl. P1, figs. 1, 2).

Synonym: Actinocyclus ingens Rattray (1890a), p. 149, pl. 11, fig. 7; Akiba (1982a), p. 42, pl. 5, figs. 7-14; Akiba (1986), p. 442, pl. 16, figs. 6, 9; Harwood and Maruyama (1992), p. 700, pl. 8, fig. 10; pl. 11, figs. 4, 6; pl. 12, fig. 8; Mahood and Barron (1996b), p. 288, pl. 3, figs. 1a-4; pl. 7, figs. 20a-21; Bohaty et al. (1998), pl. 3, fig. 7; Iwai and Winter (2002), p. 3, pl. P15, fig. 3; pl. P29, figs. 1, 4; Suto et al. (2013), p. 32, pl. P1, figs. 15, 16.

Actinocyclus ingens f. nodus (Baldauf) Whiting et Schrader (1985a), p. 74, pl. 1, fig. 3; pl. 2, fig. 11; pl. 3, fig. 14 (no illustrations).

Synonym: Actinocyclus ingens var. nodus Baldauf in Baldauf et Barron (1980), p. 104, pl. 1, figs. 5-9; Ciesielski (1986), p. 875, pl. 1, figs. 8, 9; Gersonde (1990), p. 792, pl. 1, fig. 6; pl. 3, figs. 4-7; Censarek and Gersonde (2002), p. 350 , pl. 1, fig. 4 .

Actinocyclus ingens var. ovalis Gersonde (1990), p. 792, pl. 1, fig. 7; pl. 3, figs. 1-3; pl. 5, figs. 4, 7; pl. 6, figs. 1, 4, 5; Gersonde and Burckle (1990), p. 779, pl. 5, fig. 4; Bal- dauf and Barron (1991), p. 585, pl. 5, fig. 1; Censarek and Gersonde (2002), p. 350, pl. 1, figs. 6, 8; Iwai and Winter (2002), p. 3, pl. P15, fig. 5; Bohaty et al. (2003), p. 16, pl. P1, figs. 2, 3 (Pl. P1, figs. 27, 28).

Synonym: Hemidiscus ovalis (Gersonde) Harwood et Maruyama (1992), p. 703, pl. 11, fig. 2; pl. 12, figs. 1-3.

Actinocyclus karstenii Van Heurck (1909), p. 44, pl. 12, fig. 158; Harwood (1986), p. 84, pl. 8, figs. 8-10; Harwood and Maruyama (1992), p. 700, pl. 13, figs. 1, 2, 6-8, 10, 11, 13; Mahood and Barron (1996b), p. 288, pl. 3, fig. 5; Bohaty et al. (1998), pl. 3, figs. 4, 5; Harwood et al. (2000), p. 459, figs. 7j, 7k; Censarek and Gersonde (2002), p. 350, pl. 1, fig. 5; Iwai and Winter (2002), p. 3, pl. P20, figs. 5-8; pl. P24, fig. 8; pl. P26, fig. 1; pl. P27, fig. 9; Zielinski and Gersonde (2002), p. 253, pl. 3, figs. 4, 5, 7-9, 12 (Pl. P2, figs. 5, 6).

Synonym: Actinocyclus fryxellae Barron in Baldauf et Barron (1991), pl. 1, figs. 1, 2, 4.

Actinocyclus octonarius (Ehrenberg) Kützing (1844), p. 134, pl. 21, fig. 25; Iwai and Winter (2002), p. 3, pl. P20, fig. 3; Arney et al. (2003), p. 8, pl. P3, fig. 2 (no illustrations).

Actinocyclus sp. A (Pl. P2, figs. 7, 8).

Actinoptychus senarius (Ehrenberg) Ehrenberg (1843), p. 298, 301, 322, 328, 437, 438, 443; pl. I/I, fig. 27; pl. I/III, fig. 21; pl. III/VII, fig. 1; Akiba (1986), p. 447, pl. 29, fig. 2; Censarek and Gersonde (2002), p. 350, pl. 5, fig. 11; Suto et al. (2013), p. 35, pl. P5, figs. 1-10 (Pl. P2, figs. 9, 10).

Basionym: Actinocyclus senarius Ehrenberg (1837), p. 61.

Actinoptychus vulgaris Schumann (1867), p. 64; Akiba (1986), p. 447, pl. 29, fig. 1 (Pl. P2, figs. 11, 12).

Asterolampra spp. (P1. P2, figs. 13, 14).

Asteromphalus hyalinus Karsten (1905), p. 90, pl. 8, fig. 15; Schrader (1976), p. 630, pl. 8, fig. 7; Fenner et al. (1976), p. 769, pl. 4, figs. 17-19; Akiba (1982a), p. 42, pl. 1, fig. 4; Suto et al. (2013), p. 32, pl. P1, figs. 35, 36 (no illustrations).

Asteromphalus kennettii Gersonde (1990), p. 793, pl. 2, fig. 1; pl. 6, fig. 2; Harwood and Maruyama (1992), p. 701, pl. 11, fig. 3; Censarek and Gersonde (2002), p. 350, pl. 1, fig. 2 (P1. P3, figs. 1, 2).

Synonym: Asteromphalus sp. 1 of Ciesielski (1983), p. 655 , pl. 6, figs. $1,2,6,9$.

Asteromphalus oligocenicus Schrader et Fenner (1976), pp. 965, 966, pl. 21, figs. 8, 13, 14; pl. 28, fig. 1; Gombos and Ciesielski (1983), p. 600, pl. 5, figs. 5-7; Harwood and Maruyama (1992), p. 701, pl. 4, fig. 17; pl. 5, fig. 5; Arney et al. (2003), p. 8, pl. P4, fig. 1 (Pl. P3, figs. 3, 4).

Synonym: Asterolampra sp. 2 of Schrader (1976), p. 630, pl. 8 , fig. 2 .

Asteromphalus parvulus Karsten (1905), p. 90, pl. 8, fig. 14; Fenner et al. (1976), p. 769, pl. 4, figs. 20, 21; Schrader (1976), p. 630, pl. 8, fig. 6; Akiba (1982a), p. 42, pl. 1, figs. 3, 5, 6; Koizumi (1982), p. 79, pl. 1, fig. 13; Har- 
wood and Maruyama (1992), p. 701, pl. 19, figs. 1, 2 (Pl. P3, figs. 5, 6).

Synonym: Asteromphalus symmetricus of Harwood and Maruyama (1992), p. 701, pl. 4, fig. 18.

Asteromphalus spp. (P1. P3, figs. 7, 8).

Aulacoseira granulata (Ehrenberg) Simonsen (1979), p. 58; Akiba (1986), p. 448, pl. 29, figs. 6-9; Suto et al. (2013), p. 36, pl. P9, figs. 1-8 (no illustrations).

Basionym: Gaillonella granulata Ehrenberg (1843), p. 415.

Synonym: Melosira granulata (Ehrenberg) Ralfs in Pritchard (1861), p. 820.

Azpeitia endoi (Kanaya) Sims et Fryxell in Fryxell et al. (1986), p. 16; Iwai and Winter (2002), p. 4, pl. P21, figs. 6, 7 (Pl. P4, figs. 1, 2).

Basionym: Coscinodiscus endoi Kanaya (1959), pp. 76, 77, pl. 3, figs. 8-11; McCollum (1975), p. 527, pl. 4, figs. 5, 6; Schrader (1976), p. 630, pl. 11, figs. 4, 8-10, 12; Gombos (1977), p. 593, pl. 2, figs. 6, 7; pl. 5, fig. 3; Akiba (1986), p. 442, pl. 2, fig. 2.

Synonym: Azpeitia endoi Kanaya of Arney et al. (2003), p. 8, pl. P3, fig. 5 .

Azpeitia tabularis (Grunow) Fryxell et Sims in Fryxell et al. (1986), p. 16, figs. 14-1A-14-3B, 15-1A-15-4B, 30-1; Harwood and Maruyama (1992), p. 701, pl. 11, fig. 5; Censarek and Gersonde (2002), p. 350, pl. 1, fig. 7; Iwai and Winter (2002), p. 4, pl. P21, fig. 4; Zielinski and Gersonde (2002), p. 255, pl. 3, fig. 2 (Pl. P4, figs. 3, 4).

Basionym: Coscinodiscus tabularis Grunow (1884), p. 34 (86); Schrader (1976), p. 631, pl. 11, fig. 5; Fenner et al. (1976), p. 774, pl. 7, figs. 10-13; Akiba (1982a), p. 42, pl. 2, figs. 6-9; Koizumi (1982), p. 80, pl. 2, fig. 10.

Azpeitia tabularis var. egregius (Rattray) Desikachary et al. (1987), pp. 4, 5, pl. 115, fig. 8; Zielinski and Gersonde (2002), p. 255, pl. 3, fig. 6 (no illustrations).

Basionym: Coscinodiscus egregius Rattray (1890b), p. 518, sl. no. 934.

Synonym: Coscinodiscus tabularis var. egregius (Rattray) Hustedt (1927-1930), p. 428, fig. 230b; Fenner et al. (1976), p. 774, pl. 7, figs. 8, 9; Akiba (1986), p. 442, pl. 2, figs. 3, 4 .

Azpeitia vetustissima (Pantocsek) Sims in Fryxell et al. (1986), p. 16 (Pl. P4, figs. 5-7).

Basionym: Coscinodiscus vetustissimus Pantocsek (1886), p. 73, pl. 20, fig. 186; McCollum (1975), p. 534, pl. 6, figs. 4-7; Schrader (1976), p. 631, pl. 11, fig. 11; Gombos (1977), p. 593, pl. 27, fig. 2.

Bacteriastrum spp. (Pl. P4, figs. 8-10).

Biddulphia spp. (Pl. P4, figs. 11, 12).

Bogorovia gombosii (Desikachary) Yanagisawa (1995), p. 27, figs. 4-1, 4-2, 5-1, 5-2 (Pl. P4, figs. 13, 14).

Basionym: Rossiella gombosii Desikachary in Desikachary et al. (1984), p. 338.

Synonym: Bogorovia veniamini Jousé of Schrader (1976), p. 630, pl. 5, figs. 22, 23; Gombos (1977), p. 593, pl. 1, fig.
6, 7; pl. 12, figs. 2, 4; Rossiella sp. of Gombos and Ciesielski (1983), p. 604, pl. 24, figs. 1, 2.

Cavitatus jouseanus (Sheshukova-Poretzkaya) Williams (1989), p. 360; Akiba et al. (1993), p. 20, 22, figs. 6-19, 6-20; Censarek and Gersonde (2002), p. 350, pl. 5, fig. 12; Arney et al. (2003), p. 8, pl. P2, fig. 1 (no illustrations).

Basionym: Synedra jouseana Sheshukova-Poretzkaya (1962), p. 208, fig. 4; Sheshukova-Poretzkaya (1967), p. 245 , pl. 42 , figs. $4 a, 4 b$; pl. 43 , figs. $12 \mathrm{a}, 12 \mathrm{~b}$; Schrader (1973), p. 710, pl. 23, figs. 21-23, 25, 38; McCollum (1975), p. 536, pl. 13, fig. 5; Gombos (1977), p. 598, pl. 12, fig. 7; Gombos and Ciesielski (1983), p. 605, pl. 24, figs. 37; Akiba (1986), p. 445, pl. 21, fig. 9; Harwood and Maruyama (1992), p. 706, pl. 11, figs. 8, 9.

Cestodiscus reticulatus Fenner (1984), p. 331, pl. 1, fig. 10; Harwood and Maruyama (1992), p. 701, pl. 3, fig. 4 (no illustrations).

Chaetoceros spp. (vegetative cells) (Pl. P4, figs. 15, 16).

Cocconeis californica (Grunow in Cleve et Möller) Grunow in Van Heurck (1880-1885), pl. 30, figs. 8, 9; Iwai and Winter (2002), p. 4, pl. P6, fig. 11 (Pl. P4, figs. 17, 18).

Cocconeis placentula Ehrenberg (1838), p. 194; Fenner et al. (1976), p. 771, pl. 11, fig. 13; Suto et al. (2013), p. 35, pl. P6, figs. 11-20; pl. P11, figs. 7, 8 (Pl. P4, figs. 19, 20).

Cocconeis scutellum Ehrenberg (1838), p. 194, pl. 14, fig. 8; Akiba (1986), p. 447, pl. 30, figs. 3, 11 (no illustrations).

Cocconeis sp. B of Suto et al. (2013), p. 35, pl. P6, figs. 3239; pl. P11, fig. 4 (Pl. P4, figs. 21-24).

Cocconeis spp. (no illustrations).

Coscinodiscus asteromphalus Ehrenberg (1844b), p. 77; Arney et al. (2003), p. 8, pl. P3, fig. 3; Suto et al. (2013), p. 32 , pl. P2, figs. 1, 2 (no illustrations).

Coscinodiscus marginatus Ehrenberg (1843), p. 412 (124); McCollum (1975), p. 527, pl. 16, figs. 2, 3; Schrader (1976), p. 631, pl. 10, fig. 3; pl. 12, fig. 2; Gombos (1977), p. 593, pl. 5, fig. 5; Akiba (1982a), p. 42, pl. 1, fig. 8; Akiba (1986), p. 442, pl. 1, figs. 1-4; Iwai and Winter (2002), p. 5, pl. P30, fig. 2; pl. P31, fig. 5; Arney et al. (2003), p. 8, pl. P1, fig. 1; Suto et al. (2013), p. 32, pl. P2, figs. 3, 4 (Pl. P5, figs. 1, 2).

Coscinodiscus radiatus Ehrenberg (1840b), p. 68 (148), pl. 3, figs. 1a-1c; Fenner et al. (1976), p. 774, pl. 7, fig. 1; Iwai and Winter (2002), p. 5, pl. P22, fig. 1; Suto et al. (2013), p. 32, pl. P2, figs. 5, 6 (Pl. P5, figs. 3, 4).

Costopyxis trochlea (Hanna) Strelnikova in Gleser et al. (1988), p. 51, pl. 32, figs. 17, 18; Scherer and Koç (1996), p. 86, pl. 8, figs. 8-10; Gladenkov (1998), pl. 1, figs. 11a, 11b; Tsoy (2003), pl. 2, fig. 12; Suto et al. (2009), p. 261, pl. 3, figs. 24-37 (Pl. P5, figs. 5-8).

Basionym: Trochosira trochlea Hanna (1927), p. 123, pl. 21, figs. 8, 9.

Synonym: See Suto et al. (2009). 
Crucidenticula kanayae var. kanayae Akiba et Yanagisawa (1986), p. 486, pl. 1, figs. 3-8; pl. 3, figs. 1-6, 9, 10; Gersonde and Burckle (1990), p. 780, pl. 3, figs. 11, 12; Yanagisawa and Akiba (1990), p. 229, pl. 1, figs. 33-35, 39; pl. 8, figs. 14-17; Harwood and Maruyama (1992), p. 702, pl. 7, fig. 5; Censarek and Gersonde (2002), pp. 350, 351, pl. 2, figs. 35, 36 (Pl. P5, figs. 9, 10).

Synonym: See Yanagisawa and Akiba (1990).

Crucidenticula nicobarica (Grunow) Akiba et Yanagisawa (1986), p. 486, pl. 1, fig. 9; pl. 2, figs. 1-7; pl. 5, figs. 1-9; Baldauf and Barron (1991), p. 588, pl. 7, fig. 8; Censarek and Gersonde (2002), p. 351, pl. 2, figs. 25, 26; Arney et al. (2003), p. 8, pl. P1, fig. 13 (Pl. P5, figs. 11, 12).

Basionym: Denticula nicobarica Grunow (1868), p. 97, pl. 1a, figs. $5 a, 5 b$.

Synonym: See Yanagisawa and Akiba (1990).

Cyclotella pantanelliana Castracane (1886b), p. 171; Suto et al. (2013), p. 38, pl. P9, figs. 9-18 (Pl. P5, figs. 13-16).

Cyclotella striata (Kützing) Grunow in Cleve et Grunow (1880), p. 119; Akiba (1986), p. 442, pl. 4, figs. 8-10 (no illustrations).

Basionym: Coscinodiscus striatus Kützing (1844), p. 131, pl. 1, fig. 8 .

Cyclotella sp. A (no illustrations).

Cymatosira sp. (Pl. P5, figs. 17-19).

Denticulopsis crassa Yanagisawa et Akiba (1990), pp. 248, 249, pl. 3, figs. 21-27; pl. 12, figs. 1-8; Censarek and Gersonde (2002), p. 351, pl. 2, fig. 12; Iwai and Winter (2002), p. 5, pl. P1, figs. 15-18 (Pl. P5, figs. 20-22).

Synonym: See Yanagisawa and Akiba (1990).

Denticulopsis dimorpha (Schrader) Simonsen (1979), p. 64; Akiba (1982a), pl. 11, figs. 1, 5, 6a; Akiba (1986), p. 442, pl. 27, figs. 3, 4, 7-9, 11-13; Akiba and Yanagisawa (1986), p. 488, pl. 15, figs. 2-4, 17, 18, 20, 23-25; Ciesielski (1986), p. 876, pl. 2, figs. 5-8; Baldauf and Barron (1991), p. 588, pl. 7, fig. 4; Harwood and Maruyama (1992), p. 702, pl. 6, figs. 5-7; pl. 7, fig. 10; pl. 9, figs. 5-9, 15-18, 22, 23; pl. 10, figs. 5, 6, 12, 14; Censarek and Gersonde (2002), p. 351, pl. 2, figs. 8-11 (Pl. P5, figs. 23-26). Basionym: Denticula dimorpha Schrader (1973), p. 704, pl. 1, figs. 37-44, 46.

Synonym: See Yanagisawa and Akiba (1990).

Denticulopsis katayamae Maruyama (1984), pp. 158, 159, pl. 12, figs. 1a-6; pl. 17, figs. 1-13, 15, 16, 18-23; Akiba (1986), p. 443, pl. 28, figs. 1-4; Akiba and Yanagisawa (1986), p. 489 , pl. 17, figs. $1-3,6$; pl. 19, figs. 6-9; pl. 20, figs. 1, 4, 5, 7; Yanagisawa and Akiba (1990), pp. 245, 246, pl. 3, figs. 12, 13, 28; pl. 11, fig. 4 (Pl. P5, figs. 2730).

Synonym: See Yanagisawa and Akiba (1990).

Denticulopsis lauta (Bailey) Simonsen (1979), p. 64; Maruyama (1984), pl. 14, figs. 1a-8b; pl. 16, figs. 9, 10; Akiba (1986), p. 443, pl. 26, fig. 15; Akiba and Yanagisawa (1986), p. 489, pl. 7, fig. 29; pl. 9, figs. 2-9; Yanagisawa and Akiba (1990), pp. 235, 236, pl. 2, figs. 6-8, 15; pl. 5, figs. 1-3; pl. 9, fig. 1; Baldauf and Barron (1991), p. 588, pl. 7, fig. 3 (Pl. P5, figs. 31, 32).

Basionym: Denticula? lauta Bailey (1854), p. 9, figs. 1, 2. Synonym: See Yanagisawa and Akiba (1990).

Denticulopsis maccollumii Simonsen (1979), p. 65; Gersonde and Burckle (1990), p. 780, pl. 5, figs. 7-9; Yanagisawa and Akiba (1990), pp. 264, 265, pl. 2, figs. 39-41; Harwood and Maruyama (1992), p. 702, pl. 6, fig. 22; pl. 7, fig. 17; pl. 9, fig. 27; Censarek and Gersonde (2002), p. 351, pl. 2, figs. 32-34; Iwai and Winter (2002), p. 6, pl. P3, fig. 10; Arney et al. (2003), p. 8, pl. P1, fig. 9 (Pl. P5, figs. 33-38).

Synonym: See Yanagisawa and Akiba (1990).

Denticulopsis ovata (Schrader) Yanagisawa et Akiba (1990), pp. 257, 258, pl. 6, figs. 6-14, 24-32; Censarek and Gersonde (2002), p. 351, pl. 2, figs. 13-20; Iwai and Winter (2002), p. 6, pl. P1, fig. 20 (Pl. P6, figs. 1-6).

Basionym: Denticula hustedtii var. ovata Schrader (1976), p. 632, pl. 4, figs. 5, 6, 12, 14, 15.

Synonym: See Yanagisawa and Akiba (1990), Censarek and Gersonde (2002), and Iwai and Winter (2002).

Denticulopsis simonsenii Yanagisawa et Akiba (1990), pp. 242, 243, pl. 3, figs. 1-3; pl. 11, figs. 1, 5; Censarek and Gersonde (2002), p. 351, pl. 2, figs. 21-24; Iwai and Winter (2002), p. 6, pl. P1, figs. 1-6; pl. P28, figs. 1, 2 (Pl. P6, figs. 7-12).

Synonym: See Yanagisawa and Akiba (1990).

Denticulopsis vulgaris (Okuno) Yanagisawa et Akiba (1990), pp. 243, 244, pl. 3, figs. 4-8; pl. 11, figs. 2, 6-10; Iwai and Winter (2002), p. 6, pl. P1, figs. 7, 8 (Pl. P6, figs. 13-16). Synonym: See Yanagisawa and Akiba (1990).

Diploneis bombus Ehrenberg (1844b), p. 84; Akiba (1986), p. 447, pl. 30, figs. 5, 13; Censarek and Gersonde (2002), p. 351, pl. 5, fig. 3; Suto et al. (2013), p. 35, pl. P7, figs. 1-6 (Pl. P6, figs. 17, 18).

Diploneis spp. (no illustrations).

Discostella stelligera (Cleve et Grunow) Houk et Klee (2004), p. 208; Suto et al. (2013), p. 36, pl. P9, figs. 31-44 (Pl. P6, figs. 19, 20).

Basionym: Cyclotella meneghiniana var. stelligera Cleve et Grunow in Cleve (1881), p. 22, pl. 5, figs. 63a, 63c.

Synonym: Cyclotella stelligera (Cleve et Grunow in Cleve) Van Heurck (1880-1885), pl. 94, figs. 22-26.

Distephanosira architecturalis (Brun) Gleser in Gleser et al. (1992), p. 68, pl. 56, figs. 1-9 (Pl. P6, figs. 21, 22).

Basionym: Melosira architecturalis Brun in Schmidt et al. (1874-1959), pl. 177, figs. 45-50; Gombos (1977), p. 595, pl. 26, figs. 5-7.

Eucampia antarctica (Castracane) Mangin (1915), p. 58, figs. 41, 42; pl. 1, fig. 1; Hasle and Syvertsen (1990), pl. 16.1, figs. 7-13; Mahood and Barron (1996b), p. 290, pl. 1, figs. 1-3; pl. 7, figs. 1, 2; Harwood et al. (2000), p. 459, figs. 7r, 7s; Iwai and Winter (2002), p. 6, pl. P7, fig. 12; pl. P27, fig. 6; Suto et al. (2013), p. 32, pl. P1, figs. 37, 38 (P1. P6, figs. 23-26). 
Synonym: Eucampia balaustium Castracane (1886a), p. 97, pl. 18, fig. 5; McCollum (1975), p. 534, pl. 16, figs. 8, 9; Schrader (1976), p. 632, pl. 14, fig. 7; Fenner et al. (1976), p. 774, pl. 5, figs. 7-9; Gombos (1977), p. 593, pl. 1, figs. 1, 2; pl. 11, fig. 1; Akiba (1982a), p. 43, pl. 6, figs. 1-9; Koizumi (1982), p. 80, pl. 1, fig. 12; Tanimura (1992), p. 407, fig. 3-13.

Eucampia spp. (no illustrations).

Fragilariopsis aurica (Gersonde) Gersonde et Bárcena (1998), p. 92; Censarek and Gersonde (2002), p. 351, pl. 3, figs. 9-12; Iwai and Winter (2002), pp. 6, 7, pl. P4, figs. 24-28; pl. P25, fig. 2; pl. P28, fig. 7; Zielinski and Gersonde (2002), p. 257, pl. 1, figs. 13-15 (Pl. P6, figs. 27-30).

Basionym: Nitzschia aurica Gersonde (1991), pp. 144146, pl. 1, figs. 18-25; pl. 3, fig. 5; pl. 4, figs. 5, 6; pl. 7, fig. 6; Gersonde and Burckle (1990), p. 780, pl. 2, figs. 10-12; Harwood and Maruyama (1992), p. 704, pl. 17, figs. 21-23.

Fragilariopsis barronii (Gersonde) Gersonde et Bárcena (1998), p. 92; Harwood et al. (2000), p. 459, fig. 10m; Iwai and Winter (2002), p. 7, pl. P25, fig. 3; Zielinski and Gersonde (2002), p. 257, pl. 1, figs. 29-31; Suto et al. (2013), p. 32, pl. P3, figs. 1-4 (Pl. P1, figs. 17, 18).

Basionym: Nitzschia barronii Gersonde (1991), pp. 146, 147, pl. 3, fig. 6; pl. 4, figs. 1-3; pl. 5, figs. 7-17; Gersonde and Burckle (1990), p. 780, pl. 1, figs. 11-13; Baldauf and Barron (1991), p. 589, pl. 7, fig. 14; Harwood and Maruyama (1992), p. 704, pl. 17, figs. 27, 28; Mahood and Barron (1996b), p. 290, pl. 2, figs. 3a-4; pl. 7, figs. 16, 17.

Fragilariopsis barronii/kerguelensis transitional form of Zielinski and Gersonde (2002), p. 257, pl. 1, figs. 25-28; Suto et al. (2013), p. 32, pl. P3, figs. 5-10 (no illustrations).

Fragilariopsis curta (Van Heurck) Hustedt (1958), p. 160, pl. 11, figs. $140-144$; pl. 12, fig. 159; Hasle (1965), pp. 32, 33, pl. 6, fig. 6; pl. 12, figs. 2-5; pl. 13, figs. 1-6; pl. 16, fig. 6; pl. 17, fig. 5; Bohaty et al. (1998), pl. 4, fig. 3; Harwood et al. (2000), p. 459, fig. 101 (Pl. P6, figs. 31-38).

Basionym: Fragilaria curta Van Heurck (1909), p. 24, pl. 3, fig. 37.

Synonym: Nitzschia curta (Van Heurck) Hasle (1972a), p. 115; Schrader (1976), p. 633, pl. 5, figs. 21, 23, 24; Fenner et al. (1976), p. 775, pl. 4, figs. 5-9; Akiba (1982a), p. 44, pl. 10, figs. 1-2b; Koizumi (1982), p. 80, pl. 1, figs. 1, 2; Harwood and Maruyama (1992), p. 704, pl. 17, figs. 1-4; Tanimura (1992), p. 407, figs. 4-17-4-23.

Fragilariopsis cylindrica (Burckle) Censarek et Gersonde (2002), pp. 349, 350; Suto et al. (2013), p. 32, pl. P3, figs. 11-16 (Pl. P6, figs. 39-42).

Basionym: Nitzschia cylindrica Burckle (1972), p. 239, pl. 2, figs. 1-6; Gersonde and Burckle (1990), p. 780, pl. 1, fig. 27; Baldauf and Barron (1991), p. 589, pl. 7, fig. 10; Iwai and Winter (2002), p. 8, pl. P2, figs. 5, 6.

Fragilariopsis doliolus (Wallich) Medlin et Sims (1993), p. 332; Zielinski and Gersonde (2002), p. 257, pl. 1, fig. 1; Suto et al. (2013), pp. 32, 33, pl. P3, figs. 17, 18 (Pl. P6, figs. 43,44$)$.
Basionym: Synedra doliolus Wallich (1860), p. 48, pl. 2, fig. 19.

Synonym: Pseudoeunotia doliolus (Wallich) Grunow in Van Heurck (1880-1885), pl. 35, fig. 22; Fenner et al. (1976), p. 778, pl. 14, fig. 12; Akiba (1986), p. 444, pl. 22, figs. $1,2$.

Fragilariopsis fossilis (Frenguelli) Medlin et Sims (1993), p. 332; Censarek and Gersonde (2002), p. 351, pl. 3, figs. 3, 4; Zielinski and Gersonde (2002), p. 257, pl. 1, figs. 5, 6; Suto et al. (2013), p. 33, pl. P3, figs. 19-22 (Pl. P6, figs. 45,46$)$.

Basionym: Pseudonitzschia fossilis Frenguelli (1949), p. 118, pl. 1, figs. $6,7$.

Synonym: Nitzschia fossilis (Grunow) Grunow in Van Heurck (1880-1885), pl. 68, fig. 24; Gombos (1977), p. 595, pl. 8, fig. 17; Akiba (1986), p. 443, pl. 22, figs. 6-8; Gersonde and Burckle (1990), p. 780, pl. 1, figs. 19, 20.

Fragilariopsis interfrigidaria (McCollum) Gersonde et Bárcena (1998), p. 92; Iwai and Winter (2002), p. 7, pl. P3, figs. 16, 17; pl. 25, figs. 6-8; Zielinski and Gersonde (2002), p. 259, pl. 1, figs. 20, 21; Bohaty et al. (2003), pp. 21, 22, pl. P2, figs. 15-18 (Pl. P1, figs. 13, 14).

Basionym: Nitzschia interfrigidaria McCollum (1975), p. 535, pl. 9, fig. 9; Schrader (1976), p. 634, pl. 3, figs. 5, 6; Gombos (1977), p. 595, pl. 7, fig. 3; Ciesielski (1983), p. 655, pl. 1, figs. 11-18; Ciesielski (1986), p. 876, pl. 3, figs. 6, 7; Gersonde and Burckle (1990), p. 780, pl. 1, figs. 1-3.

Synonym: Nitzschia praeinterfrigidaria of Ciesielski (1983), pl. 2, figs. 15, 16.

Fragilariopsis kerguelensis (O'Meara) Hustedt (1952), p. 294; Hustedt (1958), p. 162, figs. 121-127; Bohaty et al. (1998), pl. 1, fig. 12; Iwai and Winter (2002), p. 7, pl. P3, figs. 1-3; pl. P24, fig. 3; pl. P25, fig. 1; Zielinski and Gersonde (2002), p. 259, pl. 1, fig. 24; Bohaty et al. (2003), p. 22, pl. P2, fig. 13; Suto et al. (2013), p. 33, pl. P3, figs. 23-38; pl. P11, fig. 1 (Pl. P1, figs. 19, 20).

Basionym: Terebraria kerguelensis O'Meara (1877), p. 56, pl. 1, fig. 4 .

Synonym: Nitzschia kerguelensis (O'Meara) Hasle (1972a), p. 115, figs. 1, 2; Fenner et al. (1976), p. 776, pl. 2, figs. 19-30; Gombos (1977), p. 595, pl. 8, figs. 13, 14; pl. 9, fig. 2; Akiba (1982a), p. 44, pl. 9, figs. 1a-4b; Koizumi (1982), p. 80, pl. 1, figs. 7-11; Tanimura (1992), p. 407, figs. 3-1-3-9; Arney et al. (2003), p. 9, pl. P1, fig. 14.

Fragilariopsis maleinterpretaria (Schrader) Censarek et Gersonde (2002), p. 350, pl. 3, fig. 26.

Basionym: Nitzschia maleinterpretaria Schrader (1976), p. 634, pl. 2, figs. 9, 11-19, 21, 24; Gersonde and Burckle (1990), pp. 780, 782, pl. 2, figs. 13-16; Harwood and Maruyama (1992), p. 704, pl. 6, fig. 21 (Pl. P6, figs. 47, 48).

Fragilariopsis obliquecostata (Van Heurck) Heiden et Kolbe (1928), p. 555; Mahood and Barron (1996b), p. 290, pl. 2, figs. 1, 2; pl. 7, figs. 9-14; Bohaty et al. (1998), pl. 1, fig. 14; Suto et al. (2013), p. 33, pl. P11, fig. 2 (Pl. P6, figs. 49, 50).

Basionym: Fragilaria obliquecostata Van Heurck (1909), p. 25 , pl. 3 , fig. 38 . 
Synonym: Nitzschia obliquecostata (Van Heurck) Hasle (1972a), p. 115; Fenner et al. (1976), pp. 776, 777, pl. 2, figs. $15-18$.

Fragilariopsis oceanica (Cleve) Hasle (1965), p. 11, pl. 1, figs. 15-19; pl. 2, figs. 6-9; pl. 3, figs. 1, 2; pl. 16, figs. 1, 2 (Pl. P6, figs. 51, 52).

Basionym: Fragilaria oceanica Cleve (1873), p. 22, pl. 4, fig. 25.

Synonym: Nitzschia grunowii Hasle (1972a), p. 115; Fenner et al. (1976), p. 776, pl. 2, figs. 1-5; Akiba (1986), p. 443, pl. 24, figs. 19-21; Tanimura (1992), p. 409, figs. 4-324-35.

Fragilariopsis praeinterfrigidaria (McCollum) Gersonde et Bárcena (1998), p. 92; Censarek and Gersonde (2002), p. 352, pl. 3, figs. 22, 23; Iwai and Winter (2002), p. 7, pl. P3, figs. 13-15; Zielinski and Gersonde (2002), p. 259, pl. 1, figs. 22, 23 (Pl. P1, figs. 15, 16).

Basionym: Nitzschia praeinterfrigidaria McCollum (1975), p. 535, pl. 10, fig. 1; Gombos (1977), p. 595, pl. 7, figs. 1, 2; Ciesielski (1983), p. 655, pl. 2, figs. 1-8, 13, 14; pl. 3, fig. 5; Gersonde and Burckle (1990), p. 782, pl. 1, figs. 4-10; Baldauf and Barron (1991), p. 589, pl. 7, fig. 12.

Fragilariopsis reinholdii (Kanaya ex Schrader) Zielinski et Gersonde (2002), p. 251, pl. 1, figs. 3, 4; Censarek et Gersonde (2002), p. 352, pl. 3, figs. 1, 2 (Pl. P6, figs. 5356).

Basionym: Nitzschia reinholdii Kanaya et Koizumi (1970), pp. 58, 59 (described in Japanese); Schrader (1973), p. 708, pl. 4, figs. 12-16; pl. 5, figs. 1-9; McCollum (1975), p. 535 , pl. 16, figs. 4, 5; Akiba (1986), pp. 443, 444, pl. 22, figs. 4, 5; Ciesielski (1986), p. 877, pl. 3, figs. 1-4; Gersonde and Burckle (1990), p. 782, pl. 2, fig. 1; Iwai and Winter (2002), p. 9, pl. P25, fig. 4; pl. P28, fig. 13.

Fragilariopsis rhombica (O'Meara) Hustedt (1952), p. 296; Suto et al. (2013), p. 33, pl. P3, figs. 39, 40 (no illustrations).

Basionym: Diatoma rhombicum O'Meara (1877), p. 55, pl. 1, fig. 2 .

Synonym: Nitzschia angulata Hasle (1972a), p. 115; Fenner et al. (1976), p. 775, pl. 1, figs. 17-39; Gombos (1977), pl. 8, fig. 16; Koizumi (1982), p. 80, pl. 1, fig. 5; Ciesielski (1986), p. 876, pl. 3, fig. 13; Tanimura (1992), p. 407, figs. 4-24-4-26; Iwai and Winter (2002), p. 8, pl. P3, fig. 6.

Fragilariopsis ritscheri Hustedt (1958), p. 164, figs. 133-136; pl. 12, fig. 153; Bohaty et al. (1998), pl. 1, fig. 8; Zielinski and Gersonde (2002), p. 259, pl. 1, fig. 7 (Pl. P6, figs. 57, 58).

Synonym: Nitzschia ritscheri (Hustedt) Hasle (1965), pp. 20, 21, pl. 1, fig. 20; pl. 4, figs. 1-7; pl. 7, fig. 8; Fenner et al. (1976), p. 777, pl. 3, figs. 1-12; Akiba (1982a), p. 44, pl. 9, figs. 5-10; Koizumi (1982), p. 80, pl. 1, fig. 6; Tanimura (1992), p. 409, figs. 4-10-4-13.

Fragilariopsis separanda Hustedt (1958), p. 165, pl. 10, figs. 108-112; Zielinski and Gersonde (2002), p. 259, pl. 1, figs. 16, 17 (Pl. P6, figs. 59-64).

Synonym: Nitzschia separanda (Hustedt) Hasle (1965), pp. 26, 27, pl. 9, figs. 7-10; pl. 10, fig. 1; Fenner et al. (1976), p. 777, pl. 1, figs. 1-16; pl. 2, figs. 23-29; Akiba (1982a), p.
44, pl. 10, figs. 3-5, 9-11; Koizumi (1982), p. 80, pl. 1, figs. 3, 4; Tanimura (1992), p. 409, figs. 4-27-4-29.

Fragilariopsis sublinearis (Van Heurck) Heiden et Kolbe (1928), p. 554; Bohaty et al. (1998), pl. 1, figs. 15-17 (Pl. P7, figs. 1, 2).

Basionym: Fragilaria sublinearis Van Heurck (1909), p. 35, pl. 3, fig. 29.

Synonym: Nitzschia sublinearis (Van Heurck) Hasle of Akiba (1982a), p. 44, pl. 9, fig. 12; Tanimura (1992), p. 409, figs. 4-36-4-40.

Goniothecium rogersii Ehrenberg (1843), p. 416 (description); Ehrenberg (1854), pl. 18, figs. 92, 93 (illustrations) (Pl. P7, figs. 3, 4).

Basionym: See Suto et al. (2008) for synonymy and description of this taxon.

Grammatophora spp. (no illustrations).

Hemiaulus spp. (Pl. P7, figs. 5-12).

Hemidiscus cuneiformis Wallich (1860), p. 42, pl. 2, figs. 3, 4; Fenner et al. (1976), p. 774, pl. 11, fig. 17; Harwood and Maruyama (1992), p. 703, pl. 11, fig. 11; Censarek and Gersonde (2002), p. 352, pl. 4, fig. 5; Iwai and Winter (2002), p. 8, pl. P21, fig. 2; Zielinski and Gersonde (2002), p. 260, pl. 4, fig. 10; Suto et al. (2013), p. 33, pl. P2, figs. 9, 10 (Pl. P7, figs. 13-16).

Hemidiscus karstenii Jousé in Jousé et al. (1962), p. 78, pl. 2, figs. 7-9; McCollum (1975), p. 535, pl. 9, figs. 3, 4; Schrader (1976), p. 632, pl. 14, fig. 2; pl. 15, figs. 17, 18; Gombos (1977), p. 595, pl. 4, fig. 8; Ciesielski (1983), p. 656, pl. 3, fig. 6; pl. 4, figs. 2-5; Censarek and Gersonde (2002), p. 352, pl. 3, fig. 27; Iwai and Winter (2002), p. 8, pl. P21, fig. 5; Suto et al. (2013), p. 33, pl. P2, figs. 1114 (Pl. P1, figs. 25, 26).

Hemidiscus triangularus (Jousé) Harwood et Maruyama (1992), p. 703; Censarek and Gersonde (2002), p. 352, pl. 4, figs. 1-4 (Pl. P1, figs. 5, 6).

Basionym: Cosmiodiscus insignis f. triangula Jousé (1977), pl. 79, fig. 2; Ciesielski (1983), p. 656, pl. 5, figs. 110; Ciesielski (1986), p. 876, pl. 4, figs. 5, 6; pl. 6, figs. 7, 8.

Hemidiscus sp. 1 of Zielinski and Gersonde (2002), p. 260, pl. 4, fig. 8; Suto et al. (2013), p. 33, pl. P2, figs. 15-18 (Pl. P7, figs. 17, 18).

Hyalodiscus spp. (Pl. P7, figs. 19, 20).

Koizumia adaroi (Azpeitia) Yanagisawa (1994a), pp. 600-602, 604, figs. 8-1-8-7, 8-12, 8-13; 9-1-9-3 (Pl. P7, figs. 21, 22). Basionym: Cymatosira adaroi Azpeitia (1911), p. 201, pl. 9, fig. 5.

Synonym: See Yanagisawa (1994a).

Mediaria splendida f. tenera Schrader (1973), p. 706, pl. 3, fig. 13; Yanagisawa (1994b), pp. 419, 420, figs. 3-6-3-8, 8-1-8-7 (no illustrations).

Synonym: See Yanagisawa (1994b).

Navicula spp. (P1. P7, figs. 23, 24).

Odontella sp.? (Pl. P7, figs. 25-30). 
Opephora spp. (Pl. P7, figs. 31, 32).

Paralia sulcata (Ehrenberg) Cleve (1873), p. 7; Akiba (1986), p. 447, pl. 29, fig. 4, 5; Iwai and Winter (2002), p. 9, pl. P8, fig. 7; pl. P25, fig. 17; pl. P29, fig. 9; pl. P32, fig. 2; Arney et al. (2003), p. 9, pl. P1, fig. 5; Suto et al. (2013), p. 36, pl. P5, figs. 17-23 (Pl. P8, figs. 1-4).

Basionym: Gaillonella sulcata Ehrenberg (1838), p. 170, pl. 21, fig. 5 .

Synonym: Melosira sulcata (Ehrenberg) Kützing (1844), p. 55 , pl. 2, fig. 7 .

Pleurosigma spp. (Pl. P8, figs. 5, 6).

Podosira spp. (Pl. P8, figs. 7, 8).

Proboscia alata (Brightwell) Sundström (1986), pp. 99, 100, figs. 258-266; Iwai and Winter (2002), p. 9, pl. P5, fig. 21; Suto et al. (2013), p. 33, pl. P3, figs. 51, 52 (Pl. P8, figs. 9-14).

Basionym: Rhizosolenia alata Brightwell (1858), p. 95, pl. 5, figs. 8, 8a; Fenner et al. (1976), p. 778, pl. 13, fig. 1; Akiba (1986), p. 444, pl. 18, fig. 6; Tanimura (1992), fig. 316; Harwood and Maruyama (1992), pl. 18, figs. 15, 17.

Proboscia barboi (Brun) Jordan et Priddle (1991), p. 56, figs. 1, 2; Harwood et al. (2000), p. 460, fig. 8d; Iwai and Winter (2002), p. 9; Suto et al. (2013), pp. 33, 34, pl. P3, figs. 53, 54 (Pl. P1, figs. 9, 10).

Basionym: Pyxilla barboi Brun (1894), p. 87, pl. 5, figs. 16, 17, 23; Rhizosolenia barboi (Brun) Tempère and Peragallo (1915), p. 26, no. 47; McCollum (1975), p. 535, pl. 11, fig. 13; Schrader (1976), p. 635, pl. 9, figs. 11-13; Akiba (1986), p. 444, pl. 18, fig. 2; Ciesielski (1986), p. 877, pl. 3, fig. 22; Simonseniella barboi (Brun) Fenner (1991), p. 108, pl. 3, figs. 1, 3; Harwood and Maruyama (1992), p. 706, pl. 11, fig. 13.

Proboscia curvirostris (Jousé) Jordan et Priddle (1991), p. 57, figs. 5-7; Suto et al. (2013), p. 34, pl. P3, figs. 55, 56 (no illustrations).

Basionym: Rhizosolenia curvirostris Jousé (1959), p. 48, pl. 2, fig. 17; Jousé (1968), p. 19, pl. 3, figs. 1-3; Akiba (1986), p. 444, pl. 18, fig. 3.

Psammodictyon panduriforme (Gregory) Mann in Round et al. (1990), p. 676 (no illustrations).

Basionym: Nitzschia panduriformis Gregory (1857), p. 57, pl. 6, fig. 102; Suto et al. (2013), p. 36, pl. P6, figs. 5257; pl. P11, figs. 5, 6.

Pseudo-nitzschia heimii Manguin (1957), p. 131, pl. 6, fig. 43; Fenner et al. (1976), p. 776, pl. 3, figs. 21-23 (no illustrations).

Pseudo-nitzschia spp. (Pl. P8, figs. 15, 16).

Pseudopyxilla americana (Ehrenberg) Forti (1909), p. 28, pl. 1, fig. 6 not fig. 7; Proschkina-Lavrenko (1949), pp. 200, 201, pl. 98, figs. 4a, 4b not 4c; Sheshukova-Poretzkaya (1967), pp. 263, 264, pl. 39, figs. 2a, 2b; Hajós (1968), p. 137, pl. 38, fig. 4; Strelnikova (1974), p. 112, pl. 54, figs. 1-15; Barron (1975), pp. 151, 152, pl. 11, fig. 12; McCollum (1975), p. 535, pl. 10, fig. 11 not figs. 2, 3; Andrews (1976), pp. 19, 20, pl. 6, figs. 11, 12 not figs. 9, 10;
Schrader and Fenner (1976), p. 994, pl. 9, fig. 7; Andrews (1980), p. 33, pl. 3, fig. 6; Abbott and Ernissee (1983), p. 302, pl. 15, fig. 7; Hajós (1986), pl. 28, fig. 15; Baldauf and Barron (1987), p. 7, pl. 11, fig. 12; Harwood et al. (1989), pl. 3, fig. 20; Lee (1993), p. 43, pl. 2, fig. 9; Harwood and Bohaty (2001), p. 329, pl. 1, fig. 26; Gladenkov (2003), p. 46, pl. 7, fig. 4 (Pl. P8, figs. 17, 18).

Basionym: Rhizosolenia americana Ehrenberg (1854), pl. 18, figs. 98b, 98d not figs. 98a, 98c, 98e-98i.

Synonym: Pyxilla americana (Ehrenberg) Grunow in Van Heurck (1880-1885), pl. 83, figs. 1-3; Pantocsek (1903), p. 45, pl. 28, fig. 283; Hanna (1970), p. 192, fig. 61; Pseudopyxilla capreolus Forti (1909), p. 16, pl. 1, fig. 4; Proschkina-Lavrenko (1949), p. 201, pl. 98, figs. 5a-5c; Pseudopyxilla capreolus var. gracilior Forti (1909), p. 17, pl. 1, fig. 5.

Remarks: Pyxilla americana in Van Heurck (1880-1885, pl. 83, figs. 1-3), Pantocsek (1903, p. 45, pl. 28, fig. 283) and Hanna (1970, p. 192, fig. 61), Pseudopyxilla capreolus in Forti (1909, p. 16, pl. 1, fig. 4) and Proschkina-Lavrenko (1949, p. 201, pl. 98, figs. 5a-5c), and Pseudopyxilla capreolus var. gracilior Forti (1909, p. 17, pl. 1, fig. 5) are synonym of Pseudopyxilla americana because these specimens possess the branching process on the top of conical valve.

Rhizosolenia americana in Ehrenberg (1854, pl. 18, figs. 98a, 98h, 98i), and Pseudopyxilla americana in Forti (1909, pl. 1, fig. 7), Proschkina-Lavrenko (1949, pl. 98, fig. 4c) and Hajós and Stradner (1975, p. 933, pl. 12, fig. 3) belong to Pseudopyxilla dubia (Grunow in Van Heurck) Forti because the cylindrical and convex valve without branching process.

The specimens of Rhizosolenia americana in Ehrenberg (1854, pl. 18, figs. 98c, 98g), McCollum (1975, pl. 10, figs. 2, 3) and Andrews (1976, pl. 6, figs. 9, 10), Pyxilla americana in Hasegawa (1977, p. 86, pl. 26, fig. 10), and Pseudopyxilla americana in Abbott and Andrews (1979, p. 249, pl. 5, fig. 6) are identified as Pseudopyxilla directa (Pantocsek) Forti because of their cylindrical and conical valve with slender hyaline process (see also Suto et al., 2009).

Pterotheca aculeifera (Grunow in Van Heurck) Van Heurck (1880-1885), pl. 83 bis, fig. 5; Suto et al. (2009), pp. 282, 284, 286, pl. 9, figs. 1-47 (Pl. P8, figs. 19, 20).

Synonym: See Suto et al. (2009).

Rhaphoneis amphiceros (Ehrenberg) Ehrenberg (1844b), p. 87; Akiba (1986), p. 447, pl. 20, fig. 19; Ciesielski (1986), p. 877 , pl. 6, figs. 1-3; Suto et al. (2013), p. 36, pl. P6, figs. 58-63 (no illustrations).

Basionym: Cocconeis amphiceros Ehrenberg (1840a), p. 206.

Rhaphoneis spp. (no illustrations).

Rhizosolenia hebetata Bailey (1856), p. 5, pl. 1, figs. 18, 19; Suto et al. (2013), p. 34, pl. P3, figs. 63-68 (Pl. P8, figs. 21, 22).

Rhizosolenia polydactyla Castracane (1886a), p. 71, pl. 24, fig. 2; Suto et al. (2013), p. 34, pl. P3, figs. 69-74 (Pl. P8, figs. 23-26).

Synonym: Rhizosolenia styliformis Brightwell of Schrader (1976), p. 635, pl. 9, fig. 4; Fenner et al. (1976), p. 779, pl. 13, figs. 3-5, 9; Akiba (1982a), p. 44, pl. 7, fig. 3 
not fig. 4; Harwood and Maruyama (1992), p. 705, pl. 18, fig. 20; Mahood and Barron (1996b), p. 292, pl. 1, fig. 7; pl. 7, figs. 4, 6; Iwai and Winter (2002), p. 10, pl. P7, figs. 1-3; pl. P28, figs. 18, 19. See also Armand and Zielinski (2001) and Suto et al. (2013).

Rocella praenitida (Fenner) Fenner in Kim et Barron (1986), p. 177, pl. 4, fig. 3; Harwood and Maruyama (1992), p. 705, pl. 4, figs. 1-5; Arney et al. (2003), p. 9, pl. P4, fig. 5 (Pl. P8, figs. 27, 28).

Basionym: Coscinodiscus praenitidus Fenner in Schrader et Fenner (1976), p. 972, pl. 14, figs. 7-9, 12; pl. 27, fig. 8; pl. 35, fig. 24; pl. 36, fig. 5; Gombos and Ciesielski (1983), p. 601, pl. 22, figs. 4, 5; Ciesielski (1986), p. 876, pl. 6, fig. 11.

Rouxia constricta Zielinski et Gersonde (2002), p. 251, pl. 2, figs. 11-19; Zielinski et al. (2002), pl. 1, figs. 8-14 (Pl. P8, figs. 29, 30).

Rouxia diploneides Schrader (1973), p. 710, pl. 3, figs. 24, 25; McCollum (1975), p. 535, pl. 11, figs. 11, 12; Harwood and Maruyama (1992), p. 705, pl. 17, fig. 12; Iwai and Winter (2002), p. 10, pl. P5, fig. 8 (Pl. P1, figs. 11, 12).

Rouxia leventerae Bohaty et al. (1998), pp. 444, 445, pl. 1, figs. 1-6; Zielinski and Gersonde (2002), p. 261, pl. 2, figs. 1-7; Zielinski et al. (2002), pl. 1; figs. 1-7 (Pl. P8, figs. 31,32 ).

Rouxia naviculoides Schrader (1973), p. 710, pl. 3, figs. 2732; McCollum (1975), p. 535, pl. 11, figs. 14, 15; Schrader (1976), p. 636, pl. 5, figs. 13, 18; Gombos (1977), p. 597, pl. 7, figs. 10, 11; Gersonde and Burckle (1990), p. 782, pl. 4, fig. 16; Harwood et al. (2000), p. 460, fig. 9r; Iwai and Winter (2002), p. 10, pl. P5, figs. 1, 2; Zielinski and Gersonde (2002), p. 261, pl. 2, figs. 8, 9 (P1. P8, figs. 33, 34).

Shionodiscus gracilis (Karsten) Alverson et al. (2006), p. 259 (Pl. P1, figs. 21, 22).

Basionym: Coscinodiscus gracilis Karsten (1905), p. 78, pl. 3, fig. 4 .

Synonym: Thalassiosira gracilis (Karsten) Hustedt (1958), pp. 109, 110, pl. 3, figs. 4-7; Fenner et al. (1976), p. 780, pl. 9, figs. 12-20; Akiba (1982a), p. 46, pl. 4, figs. 11a-12; Koizumi (1982), p. 81, pl. 2, figs. 4, 5; Tanimura (1992), p. 409, figs. 3-3-3-6; Iwai and Winter (2002), p. 12, pl. P12, fig. 4; pl. P24, fig. 2; Suto et al. (2013), p. 34, pl. P2, figs. 26, 27.

Shionodiscus oestrupii (Ostenfeld) Alverson et al. (2006), p. 258 (P1. P9, figs. 1-6).

Basionym: Coscinosira oestrupii Ostenfeld (1900), p. 52. Synonym: Thalassiosira oestrupii (Ostenfeld) Proschkina-Lavrenko ex Hasle (1960), p. 8, pl. 1, figs. 5, 7, 11; Hasle (1972b), p. 544; Fenner et al. (1976), p. 780, pl. 9, figs. 1-11; Gombos (1977), p. 598, pl. 5, figs. 1, 2; Akiba (1982a), p. 46, pl. 4, figs. 2a, 2b, 8-10; Koizumi (1982), p. 81, pl. 2, figs. 1-3; Akiba (1986), p. 446, pl. 14, figs. 1-6; Gersonde and Burckle (1990), p. 782, pl. 3, figs. 13, 14; Harwood and Maruyama (1992), p. 708, pl. 16, figs. 5-7; Bohaty et al. (1998), pl. 2, fig. 3; Censarek and Gersonde (2002), p. 353, pl. 5, figs. 9, 10; Iwai and Winter (2002), p. 13, pl. P26, figs. 6a, 6b; Suto et al. (2013), p. 35, pl. P4, figs. $1-10$.
Shionodiscus tetraoestrupii (Bodén) Alverson et al. (2006), p. 260 (P1. P9, figs. 7, 8).

Basionym: Thalassiosira tetraoestrupii Bodén (1993), pp. 63, 67, pl. 1, figs. A-G; pl. 2, figs. A, B, H, J; Mahood and Barron (1995), figs. 9-19, 25, 26, 28-46; Mahood and Barron (1996b), p. 296; Iwai and Winter (2002), p. 13, pl. P16, figs. 8, 9; pl. P27, fig. 7 .

Shionodiscus tetraoestrupii var. reimeri (Mahood et Barron) Alverson et al. (2006), p. 260 (Pl. P1, figs. 3, 4).

Basionym: Thalassiosira tetraoestrupii var. reimeri Mahood et Barron (1995), p. 2, figs. 1-8, 20-24, 27; Mahood and Barron (1996b), p. 296, pl. 4, figs. 6a-7; pl. 8, figs. 912; Zielinski and Gersonde (2002), p. 264, pl. 5, figs. 6-9.

Synonym: Coscinodiscus donahue Mukhina in Jousé (1977), pl. 79, fig. 6 not figs. 3-5, 8 .

Stellarima spp. (no illustrations).

Stephanogonia hanzawae Kanaya (1959), pp. 118, 119, pl. 11, figs. 3a-7; McCollum (1975), p. 535, pl. 12, fig. 6; Arney et al. (2003), p. 10, pl. P1, fig. 12 (no illustrations).

Synonym: Stephanogonia sp. in Iwai and Winter (2002), p. 10, pl. P8, figs. 3, 4; pl. P31, fig. 3.

Stephanopyxis spp. (Pl. P9, figs. 9-18).

Synedropsis recta Hasle et al. (1994), p. 252, figs. 27-30, 51$55,57-60,68-75,142 \mathrm{c}$ (Pl. P9, figs. 19-22).

Tetracyclus sp. (P1. P9, figs. 23, 24).

Thalassionema nitzschioides (Grunow) Mereschkowsky (1902), p. 78; Akiba (1982a), p. 45, pl. 8, figs. 15a-18; Akiba (1986), p. 445, pl. 21, figs. 11, 19; Suto et al. (2013), p. 36, pl. P8, figs. 35-48 (Pl. P9, figs. 25-40).

Basionym: Synedra nitzschioides Grunow (1862), p. 403, pl. 5/8, fig. 18 .

Synonym: Thalassionema nitzschioides (Grunow) Van Heurck (1896), p. 319, fig. 75; Ciesielski (1986), p. 877, pl. 3, fig. 17; Iwai and Winter (2002), p. 11, pl. P5, fig. 18.

Thalassionema sp. A (P1. P10, figs. 1-10).

Remarks: The valve of this taxon possesses slender and linear outline with slightly compressed and rounded ends that can easily be separated from other Thalassionema taxa with broadly rounded ends to lanceolate with subcapitate ends such as Thalassionema nitzschioides complex (Tanimura et al., 2007) and Thalassionema schraderi (Akiba, 1982b). The stratigraphic occurrence in Hole U1371D ranges from Samples 329-U1371D-9H-7W, 58-59 cm to 6H-6W, 81-82 cm (82.98-53.71 m CSF-A) with a distinct peak, where it comprises over $50 \%$ of diatom assemblage, at Sample 9H-1W, 92-93 cm (74.82 m CSF-A) (Fig. F2; Table T1). The high occurrence may correspond to the Thalassionema increasing event in 5.7, 5.2-4.7 and 4.4-3.7 Ma reported from the Antarctic Peninsula's Pacific margin by Bart and Iwai (2012), although the taxa are differentiated. This taxon is potentially useful for diatom biostratigraphy, because it is relatively short-ranging with specific characteristics that allow for easy identification in practical stratigraphic analysis.

Thalassionema spp. (P1. P9, figs. 41-44). 
Thalassiosira complicata Gersonde (1991), pp. 150, 151, pl. 3, figs. 1, 2; pl. 5, figs. 18-20; pl. 6, figs. 1-6; pl. 7, figs. 1-5; Gersonde and Burckle (1990), p. 782, pl. 4, figs. 1, 2; Harwood and Maruyama (1992), p. 707, pl. 14, figs. 18-21; Iwai and Winter (2002), pp. 11, 12, pl. P11, figs. 1-9; pl. P12, fig. 1; pl. P26, fig. 3; Zielinski and Gersonde (2002), p. 263, pl. 4, figs. 3, 4 (Pl. P10, figs. 11, 12).

Thalassiosira eccentrica (Ehrenberg) Cleve emend. Fryxell et Hasle (1972), p. 302, figs. 1-18; Fenner et al. (1976), p. 779, pl. 10, figs. 1, 2, 4, 5; Akiba (1986), p. 445, pl. 14, fig. 13; Bohaty et al. (2003), p. 25, pl. P1, fig. 6; Suto et al. (2013), p. 34, pl. P2, figs. 21-23 (Pl. P10, figs. 13-16). Basionym: Coscinodiscus eccentricus Ehrenberg (1840b), p. 146.

Thalassiosira fasciculata Harwood et Maruyama (1992), p. 707, pl. 15, figs. 4-6; Mahood and Barron (1996a), pp. 287, 289, 291, figs. 15-24, 27, 28; Zielinski and Gersonde (2002), p. 263, pl. 5, figs. 3, 4 (Pl. P10, figs. 17-20).

Synonym: Coscinodiscus bullatus Janisch of Hustedt (1958), figs. 26-28.

Thalassiosira insigna (Jousé) Harwood et Maruyama (1992), p. 707, pl. 14, figs. 3-5; Zielinski and Gersonde (2002), p. 264, pl. 5, figs. 14, 15; Bohaty et al. (2003), p. 26, pl. P1, fig. 4 (Pl. P1, figs. 7, 8).

Basionym: Cosmiodiscus insignis Jousé (1959), pl. 4, fig. 9; McCollum (1975), p. 527, pl. 8, fig. 5; Gombos (1977), p. 593, pl. 4, figs. 4, 5; Ciesielski (1986), p. 876, pl. 1, figs. 1-5.

Thalassiosira inura Gersonde (1991), p. 151, pl. 6, figs. 7-14; pl. 8, figs. 1-6; Gersonde and Burckle (1990), p. 782, pl. 3, figs. 15-17; pl. 5, fig. 14; Harwood and Maruyama (1992), p. 707, pl. 5, fig. 14; pl. 14, figs. 12-16; Bohaty et al. (1998), pl. 4, fig. 8; Harwood et al. (2000), p. 460, fig. 7b; Censarek and Gersonde (2002), p. 353, pl. 4, figs. 11, 12; Iwai and Winter (2002), p. 12, pl. P12, figs. 2, 3; pl. P26, figs. 8, 9; pl. P27, fig. 3; Zielinski and Gersonde (2002), p. 264, pl. 5, figs. 12, 13 (Pl. P1, figs. 23, 24).

Synonym: Cestodiscus? sp. of Gombos (1977), pl. 5, fig. 8; Thalassiosira gracilis of McCollum (1975), p. 536, pl. 14, fig. 3.

Thalassiosira kolbei (Jousé) Gersonde (1990), p. 793, pl. 1, fig. 2; pl. 5, figs. 3, 5, 6; Gersonde and Burckle (1990), p. 782, pl. 3, fig. 1; Mahood and Barron (1996b), p. 294, pl. 4, figs. 1, 2; pl. 8, figs. 1a, 1b; Zielinski and Gersonde (2002), p. 264, pl. 5, fig. 2 (Pl. P10, figs. 21, 22).

Basionym: Coscinodiscus kolbei Jousé in Jousé et al. (1962), p. 73, pl. 1, figs. 7-9; McCollum (1975), p. 527, pl. 4, figs. 7-9; Gombos (1977), p. 593, pl. 6, fig. 3; Ciesielski (1986), p. 875, pl. 4, figs. 1-4.

Thalassiosira lentiginosa (Janisch in Schmidt) Fryxell (1977), p. 103, figs. 13a-13d, 14a-14d; Harwood and Maruyama (1992), p. 707, pl. 19, fig. 15; Tanimura (1992), p. 409, figs. 3-1, 3-9; 5-1, 5-2; Mahood and Barron (1996b), p. 294, pl. 4, figs. 4a-5; pl. 8, figs. 2a, 2b; Bohaty et al. (1998), pl. 3, fig. 3; Iwai and Winter (2002), p. 13, pl. P20, figs. 1, 4; pl. P24, fig. 4; Suto et al. (2013), p. 35, pl. P2, figs. 28, 29 (Pl. P11, figs. 1, 2).

Basionym: Coscinodiscus lentiginosus Janisch in Schmidt (1874-1959), pl. 58, fig. 11; McCollum (1975), p. 527, pl.
5, fig. 1; Fenner et al. (1976), p. 773, pl. 7, figs. 4-6; Gombos (1977), p. 593, pl. 3, figs. 4, 5 .

Thalassiosira lineata Jousé (1968), p. 13, pl. 1, figs. 1, 2; Fenner et al. (1976), p. 780, pl. 11, figs. 8-10; Akiba (1982a), p. 46, pl. 4, figs. 3, 4; Akiba (1986), p. 446, pl. 14, figs. 7, 9; Suto et al. (2013), p. 35, pl. P2, figs. 30-33 (no illustrations).

Thalassiosira cf. nativa Sheshukova-Poretzkaya (1959), p. 41, pl. 1, fig. 8; pl. 4, fig. 5; Schrader (1976), p. 636, pl. 12, figs. 8-11; Baldauf and Barron (1991), p. 591, pl. 6, fig. 5; Iwai and Winter (2002), p. 13, pl. P19, fig. 9, 10 (Pl. P11, figs. 3, 4).

Thalassiosira nordenskioeldii Cleve (1873), p. 7, pl. 1, fig. 1; Gombos (1977), p. 598, pl. 4, figs. 6, 7; Akiba (1986), p. 446 , pl. 5, fig. 8 (no illustrations).

Thalassiosira oliverana (O'Meara) Sournia in Sournia et al. (1979), p. 191, figs. 8, 9; Harwood and Maruyama (1992), p. 708, pl. 14, figs. 1, 2, 6, 11, 17; Mahood and Barron (1996b), p. 296, pl. 5, figs. 1-3; pl. 8, figs. 3-4; Harwood et al. (2000), p. 460, fig. 7c; Suto et al. (2013), p. 35, pl. P4, figs. 31, 32 (Pl. P11, figs. 5, 6).

Basionym: Actinocyclus oliveranus O'Meara (1877), p. 58, pl. 1, fig. 7 .

Synonym: Schimperiella antarctica (Grunow) Karsten (1905), p. 88, pl. 8, figs. 6a, 6b; Fenner et al. (1976), p. 779, pl. 14, figs. 1-5; Akiba (1982a), p. 45, pl. 3, figs. 1-6; Koizumi (1982), p. 81, pl. 3, figs. 1-4; Tanimura (1992), figs. 37a, 3-7b; Thalassiosira oliverana (O'Meara) Makarova et Nikolaev (1984), p. 89, pl. 1, figs. 1-11; pl. 2, figs. 1-11; Iwai and Winter (2002), p. 13, pl. P14, figs. 1, 2; pl. P33, fig. 8; Zielinski and Gersonde (2002), p. 264.

Thalassiosira oliverana var. sparsa Harwood et Maruyama (1992), p. 708, pl. 16, fig. 13; Censarek and Gersonde (2002), p. 353, pl. 5, figs. 1, 2; Iwai and Winter (2002), p. 13, pl. P14, fig. 4; pl. P33, fig. 9 (Pl. P11, figs. 7, 8).

Basionym: Coscinodiscus (Cestodiscus) intersectus Brun (1891), p. 22, pl. 20, fig. 5 .

Synonym: Cosmiodiscus intersectus (Brun) Jousé (1959), pl. 2, figs. 3, 4; McCollum (1975), p. 527, pl. 8, fig. 4; Schrader (1976), p. 631, pl. 12, fig. 13; Gersonde and Burckle (1990), p. 780, pl. 4, fig. 13; Baldauf and Barron (1991), p. 588, pl. 6, figs. 3, 6.

Thalassiosira striata Harwood et Maruyama (1992), p. 708, pl. 15, figs. 7-9; Iwai and Winter (2002), p. 13, pl. P15, fig. 4; pl. P27, fig. 2; Zielinski and Gersonde (2002), p. 264, pl. 4, fig. 7; Suto et al. (2013), p. 35, pl. P4, figs. 11, 12 (Pl. P11, figs. 9, 10).

Thalassiosira cf. symmetrica Fryxell et Hasle (1972), p. 312, figs. 37-46; Fenner et al. (1976), p. 780, pl. 11, figs. 1-3 (Pl. P11, figs. 11, 12).

Thalassiosira tumida (Janisch) Hasle in Hasle et al. (1971), pp. 326, 328, figs. 1-43, 46; Fenner et al. (1976), p. 780, pl. 10, figs. 6, 7; Akiba (1982a), p. 46, pl. 4, figs. 1a, 1b; Bohaty et al. (1998), pl. 2, fig. 1 (Pl. P11, figs. 13, 14).

Basionym: Coscinodiscus tumidus Janisch in Schmidt (1874-1959), pl. 59, figs. 38, 39. 
Thalassiosira vulnifica (Gombos) Fenner (1991), p. 108, pl. 2, fig. 2; Harwood and Maruyama (1992), p. 702, pl. 15, fig. 1; emend. Mahood et Barron (1996a), pp. 285, 287, figs. 1-14, 25, 26; Iwai and Winter (1992), p. 708, pl. P15, fig. 1; Zielinski and Gersonde (2002), p. 264, pl. 5, figs. 10, 11 (Pl. P11, figs. 15, 16).

Basionym: Coscinodiscus vulnificus Gombos (1977), p. 593, pl. 4, figs. 1-3; pl. 42, figs. 1, 2; Ciesielski (1983), p. 656 , pl. 6, figs. 7,8 .

Synonym: Coscinodiscus sp. 2 of McCollum (1975), p. 527, pl. 8, figs. 1,2 .

Thalassiosira yabei (Kanaya) Akiba et Yanagisawa (1986), p. 493, pl. 27, figs. 1, 2; pl. 28, figs. 1-9; Akiba (1986), p. 446, pl. 7, figs. 5, 6 (Pl. P11, figs. 17, 18).

Basionym: Coscinodiscus yabei Kanaya (1959), p. 86, pl. 5, figs. 6-9; Ciesielski (1986), p. 876, pl. 4, figs. 7-10.

Thalassiosira spp. (no illustrations).

Thalassiothrix longissima Cleve et Grunow (1880), p. 108; Schrader (1976), p. 637, pl. 1, figs. 5, 6, 17; Fenner et al. (1976), p. 781; Akiba (1982a), p. 46, pl. 8, fig. 19; Akiba (1986), p. 447, pl. 21, fig. 18; Harwood and Maruyama (1992), p. 708, pl. 11, fig. 12; Suto et al. (2013), p. 35, pl. P3, figs. 75-78 (Pl. P11, figs. 19-22).

Triceratium spp. (Pl. P11, figs. 23-39).

\section{Coastal upwelling indicator, resting spores of Chaetoceros}

Coronodiscus collarius Suto (2004a), p. 96, figs. 2A, 5-35; Suto et al. (2013), p. 36, pl. P10, figs. 1, 2; pl. P12, fig. 1 (Pl. P12, figs. 1, 2).

Dicladia capreola Ehrenberg (1854), pl. 35A, fig. 8; Van Heurck (1880-1885), pl. 106, figs. 15, 16 (not fig. 14); Van Heurck (1896), p. 426, fig. 144; Kanaya (1959), p. 117, pl. 11, figs. 1, 2; Sheshukova-Poretzkaya (1967), p. 213, pl. 34, figs. 1a-1c; Hanna (1970), p. 188, fig. 63; Lohman (1974), p. 351, pl. 5, fig. 10; Abbott and Andrews (1979), p. 243, pl. 4, fig. 5; pl. 7, fig. 7; Suto (2003), pp. 337, 339, figs. 1B, 17-30, 124, 125; Suto (2005a), p. 359, fig. 2B; Suto et al. (2013), p. 36, pl. P10, figs. 3-6 (Pl. P12, figs. 3, 4).

Synonym: Chaetoceros (Dicladia) lorenzianus Grunow (1863), p. 157, pl. 5, fig. 13; Frenguelli (1949), p. 139, pl. 4, figs. 23, 24; Proschkina-Lavrenko (1949), p. 139, pl. 47, fig. 4b; Jousé (1977), pl. 24, fig. 17; Andrews (1980), p. 26, pl. 1, fig. 13; Gersonde (1980), p. 300, pl. 16, fig. 12; Harwood and Maruyama (1992), pl. 18, figs. 11, 18, 19; Lee (1993), p. 34, pl. 3, fig. 28; Chaetoceros dicladia Castracane (1886a), p. 82, pl. 8, fig. 1; pl. 19, figs. 7, 8; Barron (1975), p. 128, pl. 5, fig. 7; Lee (1993), p. 33, pl. 2, figs. 5, 6, 27?; pl. 3, fig. 29; Dicladia mitra Bailey of Van Heurck (1880-1885), pl. 106, fig. 13; Dicladia pylea Hanna et Grant (1926), p. 142, pl. 16, figs. 4, 5; Schrader (1973), pl. 17, figs. 1-3; Hasegawa (1977), p. 85, pl. 21, figs. 5a, 5b; pl. 12, figs. 12a, 12b; pl. 27, figs. 17a, 17b; Chaetoceros mitra (Bailey) Cleve of Winter (2001), p. 9, pl. P6, fig. 7.
Dispinodiscus pilusus var. montanus Suto (2004b), pp. 87, 89, figs. 1M-1R, 45-56; Suto et al. (2013), p. 36, pl. P10, figs. 11-16; pl. P12, fig. 2 (no illustrations).

Synonym: Resting spore 1 of Hasegawa (1977), p. 91, pl. 23, fig. 9; Resting spore of Stockwell (1991), pl. 1, figs. 3, 4; Chaetoceros cf. sp. 1 of Homann (1991), p. 76, pl. 9, figs. 1, 9; Chaetoceros sp. of Bohaty et al. (1998), pl. 5, fig. 7.

Dispinodiscus pilusus var. pilusus Suto (2004b), pp. 81, 87, figs. 1A-1I, 57-88; Suto et al. (2013), p. 36, pl. P10, figs. 17, 18 (Pl. P12, figs. 5, 6).

Synonym: Chaetoceros debilis Cleve of Jousé (1977), pl. 2, fig. 14; Resting spore 2 of Hasegawa (1977), p. 91, pl. 23, fig. 10; Chaetoceros sp. of Bohaty et al. (1998), pl. 5, fig. 6; Xanthiopyxis sp. of Fenner (1995), p. 79, pl. 4, fig. 8; Resting spore of Takahashi et al. (2003), figs. 7-26, 7-27.

Dispinodiscus stimulus Suto (2004b), pp. 80, 81, figs. 1J-1L, 6-31, 43, 44; Suto et al. (2013), p. 36, pl. P10, figs. 1924e (no illustrations).

Synonym: Chaetoceros sp. of Fenner (1978), p. 513, pl. 34, figs. 7, 10.

Dispinodiscus sp. A (Pl. P12, figs. 7, 8).

Gemellodiscus bifurcus Suto (2004c), p. 269, figs. 2.F, 2.G, 10.1-10.25; Suto et al. (2013), p. 37, pl. P10, figs. 25-34; pl. P12, fig. 3 (Pl. P12, figs. 9, 10).

Synonym: Chaetoceros furcellatus Bailey of SheshukovaPoretzkaya (1967), p. 205, pl. 33, fig. 8; Hajós (1968), p. 129, pl. 34, fig. 2; Gleser et al. (1974), pl. 58, fig. 3; pl. 88, fig. 4; Shirshov (1977), pl. 2, fig. 17; Sancetta (1982), pl. 2, figs. 7, 9; Lee (1993), p. 33, pl. 1, fig. 11; Chaetoceros sp. IV of Hajós (1968), p. 130, pl. 34, fig. 10; Chaetoceros septentrionalis Oestrup of Sancetta (1982), pl. 2, fig. 8; Chaetoceros didymus Ehrenberg of Whiting and Schrader (1985b), pl. 5, fig. 4 .

Gemellodiscus cingulus var. cingulus Suto (2004c), p. 267, figs. 2.C, 2.D, 8.1-8.10, 8.15; Suto et al. (2013), p. 37, pl. P10, figs. 35, 36 (Pl. P12, figs. 11, 12).

Synonym: Chaetoceros cinctus Gran of SheshukovaPoretzkaya (1967), p. 206, pl. 33, fig. 9; Gleser et al. (1974), pl. 54, figs. 1a, 1b; pl. 80, fig. 6 not pl. 48, fig. 7; Chaetoceros incurvus Bailey of Sheshukova-Poretzkaya (1967), p. 207, pl. 8, fig. 8; pl. 33, fig. 10; Chaetoceros didymus Ehrenberg of Hanna (1970), p. 182, figs. 62, 98 not fig. 97.

Gemellodiscus cingulus var. longus Suto (2004c), pp. 267, 269, figs. 2.E, 8.11-8.14; 9.1-9.15 (no illustrations).

Synonym: Chaetoceros cinctus Gran of Hajós (1968), p. 129, pl. 33, figs. 18, 19; pl. 34, fig. 1; Schrader (1973), pl. 17, figs. 14, 15; Gleser et al. (1974), pl. 48, fig. 7; pl. 80, fig. 6 not pl. 54, figs. 1a, 1b; Hasegawa (1977), p. 81, pl. 23, fig. 16; Jousé (1977), pl. 24, fig. 15; Lee (1993), p. 32, pl. 1, fig. 13; Chaetoceros spores (cf. radicans) of Whiting and Schrader (1985b), pl. 5, fig. 2 not fig. 3; Chaetoceros sp. B of Lee (1993), p. 37, pl. 1, fig. 10.

Gemellodiscus geminus Suto (2004c), p. 278, figs. 2.N, 14.514.9, 16.1-16.24 (Pl. P12, figs. 13, 14).

Synonym: Chaetoceros didymus Ehrenberg of Makarova (1962), p. 50, pl. 4, figs. 7-14; Hanna (1970), p. 182, fig. 97 
not figs. 62, 98; Jousé (1977), pl. 24, figs. 10, 11; Harwood and Bohaty (2000), p. 91, pl. 2, figs. j, k; Chaetoceros sp. V of Hajós (1968), p. 131, pl. 34, fig. 14; Chaetoceros debilis Cleve of Schrader (1973), pl. 17, figs. 12, 13; Chaetoceros sp. of Schrader and Fenner (1976), p. 968, pl. 6, fig. 15; pl. 38, figs. 5, 7 not fig. 6; Barron and Mahood (1993), p. 38, pl. 6, figs. 3,4 .

Gemellodiscus hirtus Suto (2004c), p. 269, figs. 2.H, 10.2610.31 (no illustrations).

Gemellodiscus micronodosus Suto (2004c), figs. 2.J-2.M, 12.1-12.14, 14.1 (no illustrations).

Hypovalves of Gemellodiscus caveatus and Gemellodiscus micronodosus of Suto (2004c), pp. 271, 278, figs. 2.M, 13.113.14, 14.4; Suto et al. (2013), p. 37, pl. P10, figs. 37, 38 (see also Suto, 2004d) (no illustrations).

Same type hypovalve: Xanthiopyxis sp. A of Lee (1993), p. 46 , pl. 2, fig. 14 .

Liradiscus castaneus var. castaneus Suto (2007), p. 146, figs. 2H-2J; pl. 2, figs. 1a-3c, 7a, 7b, 14a, 14b; Suto et al. (2013), p. 37, pl. P10, figs. 39-46; pl. P12, fig. 4 (Pl. P12, figs. 15-18).

Liradiscus castaneus? (P1. P12, figs. 19-26)

Liradiscus japonicus Suto (2004e), pp. 69-70, figs. 2L, 2M; pl. 3, figs. 1a-10; Suto (2007), p. 150, figs. 3G, 3H; Suto et al. (2013), p. 37, pl. P10, figs. 47, 48 (Pl. P12, figs. 27, 28).

Liradiscus pacificus Suto (2004e), p. 70, figs. 2P, 2Q; pl. 3, figs. 11a-15; Suto (2007), p. 150, figs. 3O, 3P; Suto et al. (2013), p. 37, pl. P10, figs. 49, 50 (no illustrations).

Synonym: Liradiscus ovalis Greville of Andrews (1976), p. 16, pl. 5, figs. 6-7.

Liradiscus petasus Suto (2004e), p. 70, figs. 2N, 2O; pl. 2, figs. 26a-35; Suto (2007), p. 150, figs. 3I, 3J; pl. 3, figs. 10a-13b (Pl. P12, figs. 29, 30).

Liradiscus plicatulus Hajós (1968), p. 114, pl. 28, fig. 10; Suto (2004e), p. 66, figs. 2F, 2G; pl. 2, figs. 1a-20b; Suto (2007), p. 150, figs. 3A, 3B; Suto et al. (2013), p. 37, pl. P10, figs. 51-54; pl. P12, fig. 5 (Pl. P12, figs. 31-34).

Quadrocistella paliesa Suto (2006a), p. 17, fig. 2L; pl. 6, figs. 1-24 (P1. P12, figs. 35, 36).

Synonym: Chaetoceros? sp. VI of Hajós (1968), p. 131, pl. 34, figs. 12,13 .

Quadrocistella palmesa Suto (2006a), p. 20, fig. 2N; pl. 5, figs. 18-23 (no illustrations).

Quadrocistella rectagonuma Suto (2006a), p. 17, fig. 2J; pl. 5, figs. 1-13; Suto et al. (2013), p. 37, pl. P10, figs. 57-62; pl. P12, fig. 6 (no illustrations).

Quadrocistella sp. A (Pl. P12, figs. 37-40).

Syndendrium altantemna Suto (2005a), p. 369, figs. 2M, 94107, 117 (Pl. P13, figs. 1, 2).

Syndendrium diadema Ehrenberg (1854), pl. 35A, group 18, fig. 13; Van Heurck (1896), p. 427, fig. 146; Lohman (1974), p. 350, pl. 5, fig. 13; Suto (2003), pp. 342, 348, 349 , figs. $1 \mathrm{G}, 76-93,122$; Suto (2005a), p. 365, fig. $2 \mathrm{H}$;
Suto et al. (2013), p. 37, pl. P10, figs. 63-74 (Pl. P13, figs. 3, 4).

Synonym: Chaetoceros diadema (Ehrenberg) Gran (1897), p. 20, pl. 2, figs. 16-18; Frenguelli (1949), p. 140, pl. 4, figs. 33-35; Barron (1975), p. 128, pl. 5, fig. 5; Gersonde (1980), p. 299, pl. 16, fig. 9; Winter (2001), p. 9, pl. P6, fig. 4; Chaetoceros subsecundus (Grunow) Hustedt (1927-1930), p. 790, fig. 404; Makarova (1962), p. 48, pl. 3, figs. 6-10; Schrader (1973), pl. 17, figs. 4, 8; Gleser et al. (1974), pl. 88, fig. 5; Jousé (1977), pl. 24, fig. 9; Sancetta (1982), p. 227, pl. 2, figs. 5, 6; Lee (1993), p. 36, pl. 1, figs. 2-4; pl. 3, fig. 18.

Truncatulus tortonicus (Hajós) Suto (2006c), p. 598, figs. 8, 108-140 (Pl. P13, figs. 5-10).

Basionym: Chasea tortonica Hajós (1968), p. 117, pl. 28, figs. 18, 19; Hajós (1986), pl. 49, figs. 6-8.

Vallodiscus chinchae (Mereschkowski) Suto (2005b), pp. 22, 24, figs. 2G-2I, 69-87 (Pl. P13, figs. 11, 12).

Basionym: Chaetoceros chinchae Mereschkowsky (1889), pp. 483, 484, pl. 16, figs. 3-7.

Synonym: Chaetoceros chinchae (Mereschkowsky) Frenguelli (1949), p. 142, pl. 4, figs. 25-27; Liradiscus ellipticus Greville of Barron (1975), p. 145, pl. 9, fig. 19; Liradiscus sp. of McCollum (1975), p. 535, pl. 9, figs. 5, 6; Liradiscus asperulus Andrews (1976), p. 16, pl. 5, figs. 3-5; Abbott and Andrews (1979), p. 245, pl. 4, fig. 18; Abbott and Ernissee (1983), p. 300, pl. 17, fig. 2; Liradiscus spp. of Jousé (1977), pl. 51, figs. 10, 11; genus and species indeterminate of Fenner (1978), pl. 34, figs. 16-19.

Vallodiscus complexus Suto (2005b), p. 22, figs. 2D-2F, 3368; Suto et al. (2013), p. 37, pl. P10, figs. 75-78 (Pl. P13, figs. 13-16).

Synonym: Liradiscus ovalis Greville of Hajós (1968), p. 114, pl. 28, figs. 8, 9 not fig. 12; Hajós (1986), pl. 21, figs. 10, 11; pl. 48, fig. 6; Lee (1993), p. 42, pl. 2, fig. 23 not fig. 25; Liradiscus asperulus Andrews of Lee (1986), pl. 2, fig. 17; Lee (1993), p. 41, pl. 2, fig. 10.

Vallodiscus simplexus Suto (2005b), pp. 16, 20, 22, figs. 2A2C, 5-18 (no illustrations).

Synonym: Liradiscus ovalis Greville of Hajós (1968), p. 114, pl. 28, fig. 12 not figs. 8, 9; Lee (1993), p. 42, pl. 2, fig. 25 not fig. 23; Liradiscus sp. 1 of Fenner (1978), p. 524, pl. 37, fig. 12; Liradiscus asperulus Andrews of Hajós (1986), pl. 4 , fig. 5 .

Vallodiscus spp. (no illustrations).

Xanthioisthmus biscoctiformis (Forti) Suto (2006a), pp. 9, 10, fig. 2A; pl. 1, figs. 1-8 (Pl. P13, figs. 17, 18).

Basionym: Xanthiopyxis biscoctiformis Forti (1913), p. 1553, pl. 2, figs. 6, 10, 21; Proschkina-Lavrenko (1949), p. 87, pl. 84, figs. $11 \mathrm{a}-11 \mathrm{c}$.

Xanthioisthmus maculata (Hanna) Suto (2006a), pp. 13, 15, 16, figs. 2H, 2I; pl. 4, figs. 1-11 (Pl. P13, figs. 19, 20).

Basionym: Xanthiopyxis maculata Hanna (1932), p. 225, pl. 18, fig. 4.

Synonym: Xanthiopyxis panduraeformis Pantocsek of Schrader and Fenner (1976), p. 1003, pl. 45, fig. 7. 
Xanthioisthmus sp. A (Pl. P13, figs. 21, 22).

Xanthiopyxis acrolopha Forti (1912), p. 84; Forti (1913), p. 1556, pl. 2, figs. 22, 24, 27, 28, 30-37; Hanna (1927), p. 124, pl. 21, figs. 10, 11; Hanna (1932), p. 224; Proschkina-Lavrenko (1949), p. 86, pl. 84, figs. 2a, 2b; Kanaya (1959), p. 121, pl. 11, figs. 8a, 8b; Fenner (1978), p. 536, pl. 35, figs. 25, 26; Hajós (1986), pl. 21, figs. 16, 17 not pl. 4, fig. 8; Desikachary and Sreelatha (1989), p. 286, pl. 139, fig. 3 (Pl. P14, figs. 1-7).

Synonym: Xanthiopyxis cingulata Ehrenberg of Forti (1913), pl. 2, fig. 29; Xanthiopyxis cf. acrolopha Forti of Hajós (1976), p. 826, pl. 11, fig. 6; pl. 17, figs. 4, 10, 12; pl. 21, fig. 5; Xanthiopyxis oblonga Ehrenberg of Schrader (1976), p. 637, pl. 14, fig. 4; Xanthiopyxis sp. of Sanfilippo and Fourtanier (2003), pl. P3, fig. 10.

Xanthiopyxis circulatus Suto (2004d), p. 297, figs. 1.F, 7.187.30 (no illustrations).

Xanthiopyxis globosa Ehrenberg (1844c [1845]), p. 273; Forti (1913), p. 1557, pl. 2, figs. 39-49; Hanna (1932), p. 224, pl. 18, fig. 3; Proschkina-Lavrenko (1949), p. 87, pl. 84, figs. 12a, 12b not pl. 32, figs. 5a, 5b; Jousé (1963), p. 117, fig. 105; McCollum (1975), p. 536, pl. 15, figs. 6-9; Schrader and Fenner (1976), pl. 40, figs. 15, 17; Jousé (1977), pl. 30, fig. 49; pl. 33, fig. 10 not figs. 9, 11; Dzinoridze et al. (1978), pl. 17, fig. 2; Fenner (1978), p. 536, pl. 37, figs. 1, 2; Jousé in Dzinoridze et al. (1979), p. 62, fig. 159; Hajós (1986), pl. 16, figs. 12, 13; pl. 43, fig. 7; Homann (1991), p. 142, pl. 57, figs. 8, 13; Suto (2004d), pp. 301, 303, figs. 1.K, 14.9-14.14 (no illustrations).

Synonym: Xanthiopyxis oblonga Ehrenberg of Kanaya (1959), p. 121, pl. 11, figs. 9, 10; Gleser et al. (1974), pl. 36, fig. 7; Lee (1993), p. 45, pl. 2, fig. 21; pl. 3, figs. 13, 17 not pl. 2, figs. 11, 26; pl. 3, fig. 23.

Xanthiopyxis hirsuta Hanna et Grant (1926), p. 170, pl. 21, fig. 10; Fenner (1978), p. 536, pl. 35, figs. 7, 8; Suto (2004d), pp. 297, 299, figs. 1.I1, 1.I2, 11.25-11.28, 13.8; Suto et al. (2013), p. 37, pl. P10, figs. 79-84 (no illustrations).

Synonym: Xanthiopyxis micropunctatus Hajós (1968), p. 117, pl. 28, figs. 1, 2; Indet. sp. of Hajós (1986), pl. 10, figs. 1-4; Porifera of Hajós (1986), pl. 34, figs. 17-19.

Xanthiopyxis oblonga Ehrenberg (1844c [1845]), p. 273 (no illustration); Ehrenberg (1854), pl. 33, group 17, fig. 17; Forti (1913), pl. 2, fig. 38; Hanna and Grant (1926), p. 170, pl. 21, fig. 11; Hanna (1927), p. 124; Hanna (1932), p. 226; Lohman (1948), p. 179; Proschkina-Lavrenko (1949), p. 86, pl. 84, fig. 3; Kanaya (1957), p. 116, pl. 8, figs. 12a, 12b; Kanaya (1959), p. 121, pl. 11, figs. 9, 10; Sheshukova-Poretzkaya (1967), p. 180, pl. 24, fig. 5; pl.
26, fig. 2; Wornardt (1967), p. 72, figs. 146-149; Hajós (1968), p. 115, pl. 28, figs. 16, 17, 20, 21; Lohman (1974), p. 349, pl. 5, fig. 7; Gleser et al. (1974), pl. 31, fig. 11; pl. 36, fig. 7; pl. 40, fig. 2; Hajós (1976), p. 826, pl. 17, fig. 11; Schrader and Fenner (1976), p. 1003, pl. 39, figs. 9, 10; pl. 40, fig. 5; Hasegawa (1977), p. 90, pl. 25, figs. 22a-22c; Jousé in Dzinoridze et al. (1979), p. 62, fig. 158; Hajós (1986), pl. 21, figs. 21, 22; Lee (1993), p. 45 , pl. 2, figs. 11,26 ; pl. 3 , fig. 23 not pl. 2, fig. 21 ; pl. 3, figs. 13, 17; Harwood and Bohaty (2000), p. 94, pl. 9, figs. v, w; Suto (2004d), pp. 299, 301, figs. 1.J, 13.10, 13.11, 14.1-14.8 (Pl. P14, figs. 8, 9).

Synonym: Xanthiopyxis hystrix Forti (1913), p. 1553, pl. 2, figs. 7-9; Proschkina-Lavrenko (1949), p. 86, pl. 84, figs. 5a, 5b; Fenner (1978), p. 536, pl. 36, figs. 1, 2; Hajós (1986), pl. 4, fig. 9; pl. 16, fig. 7; Xanthiopyxis globosa Ehrenberg of Proschkina-Lavrenko (1949), p. 87, pl. 32, figs. 5a, 5b not pl. 84, figs. 12a, 12b; Jousé (1977), pl. 33, figs. 9, 11 not pl. 30, fig. 49; pl. 33, fig. 10; Schrader and Schuette (1981), p. 1192, figs. 9, 10; Stephanopyxis? limbata Ehrenberg var. crista-galli of Kanaya (1959), p. 70, pl. 30, figs. 1a, 1b; Xanthiopyxis acrolopha Forti of McCollum (1975), p. 536, pl. 15, figs. 4, 5; Dzinoridze et al. (1978), pl. 17, fig. 13; Hajós (1986), pl. 4, fig. 8; Lee (1993), p. 44, pl. 1, fig. 24; Xanthiopyxis oblonga? of Fenner (1978), pl. 35, fig. 18; Pyxidicula oblonga (Ehrenberg) Kuetzing of Desikachary and Sreelatha (1989), p. 219, pl. 142, figs. 7, 8; pl. 139, fig. 7; Xanthiopyxis Ehrenberg of Hargraves (1986), p. 72, figs. 21-23.

Xanthiopyxis polaris Gran (1904), pp. 51, 52, pl. 3, figs. 1619; Suto (2004d), figs. 1.A, 7.1-7.17; Suto et al. (2013), p. 37, pl. P10, figs. 85,86 (no illustrations).

Synonym: Chaetoceros spp. of Jousé (1977), pl. 15, fig. 15; Spora of Dzinoridze et al. (1978), pl. 15, fig. 18.

Xanthiopyxis type A (knobbly type) of Suto (2004d), p. 303, figs. 1.L1, 1.L2, 7.32-7.35, 10.1-10.28; Suto et al. (2013), p. 37, pl. P9, figs. 57-62; pl. P12, fig. 7 (Pl. P14, figs. 10, 11).

Synonym: See Suto (2004d).

Xanthiopyxis type B (short spiny type) of Suto (2004d), pp. 303, 307, figs. 1.M1, 1.M2, 12.1-12.32, 13.1-13.7; Suto et al. (2013), p. 37, pl. P9, figs. 63-78; pl. P12, fig. 8 (Pl. P14, figs. 12, 13).

Synonym: See Suto (2004d).

Xanthiopyxis type C (long spiny type) of Suto (2004d), p. 307, figs. 1.N, 12.33-12.40; Suto et al. (2013), p. 37, pl. P9, figs. 79-84 (no illustrations).

Synonym: See Suto (2004d).

Hyaline type valves of resting spores of Suto et al. (2013), p. 37, pl. P9, figs. 85-96 (no illustrations). 